УДК 902/904 https://doi.org/10.24852/2587-6112.2020.6.418.461

\title{
ВВЕДЕНИЕ В ОСМАНСКУЮ АРХЕОЛОГИЮ КРЫМА. О ПРЕДМЕТЕ НАУЧНОЙ ДИСЦИПЛИНЫ И ОСНОВНЫХ НАПРАВЛЕНИЯХ СОВРЕМЕННЫХ ИССЛЕДОВАНИЙ
}

\author{
(C)2020 г. В.E. Науменко
}

В статье рассматривается теоритический и источниковедческих блок вопросов, связанный с османской археологией Крыма, как особой научной дисциплины, изучающей материальные древности османского периода в его истории (около 1475-1783 гг.). Анализируется предмет исследований и содержание термина «османская археология», его соотношение с другими близкими, но не идентичными, понятиями в археологической науке. Реконструируются основные этапы археологических исследований памятников конца XV-XVIII вв. в регионе. В работе представлен обзор основных направлений современной «османской археологии» Крыма, начиная с 90-х гг. XX в. Делается вывод о том, что за последние десятилетия наибольший прогресс достигнут при изучении археологии османских крепостей на территории Крыма и столицы Крымского ханства - города Бахчисарая, а также в области археологического вещеведения, особенно применительно к структуре керамического комплекса этого времени.

Ключевые слова: Османская империя, Крымское ханство, эйялет Кефе, османская археология, археология крепостей, городов, поселений и некрополей, архитектурная археология, археология полей военных сражений, археологическое вещеведение.

\section{INTRODUCTION TO THE OTTOMAN ARCHAEOLOGY OF THE CRIMEA. ON THE SUBJECT OF THE SCIENTIFIC DISCIPLINE AND THE MAIN DIRECTIONS OF MODERN RESEARCH}

\section{V.E. Naumenko}

The article deals with the theoretical and source-related block of issues related to the Ottoman archaeology of the Crimea, as a special scientific discipline that studies the material antiquities of the Ottoman period in its history (about 1475-1783). The subject of research and the content of the term "Ottoman archaeology" and its relationship with other similar, but not identical, concepts in archaeological science are analyzed. The main stages of archaeological research of monuments of the late XV-XVIII centuries in the region are reconstructed. The paper presents an overview of the main directions of modern ottoman archaeology of the Crimea, starting from the 90s of the XX century. It is concluded that in recent decades, the greatest progress has been made in the study of the archaeology of Ottoman fortresses in the Crimea and the capital of the Crimean Khanate - the city of Bakhchisaray, as well as in the field of archaeological material science, especially in relation to the structure of the ceramic complex of this time.

Keywords: Ottoman empire, Crimean Khanate, eyalet Kefe, Ottoman archaeology, archaeology of fortresses, cities, settlements and necropolises; architectural archaeology, archaeology of military battlefields, archaeological material science.

Археология Крыма периода 1475-1783 гг., границы которого определяются османским завоеванием полуострова в конце XV в. и включением его в состав Российской империи в конце XVIII в., все еще остается на стадии формирования собственной источниковой базы и осмысления предмета и основных направлений исследований. Для историографии по-прежнему характерны терминологическое разнообразие при обозначении данного исторического этапа в археологической периодизации региона, недостаточ- ная разработанность понятийного аппарата для атрибуции основных категорий памятников и массового археологического материала, отсутствие очерка истории изучения и анализа особенностей археологических объектов для конца XV-XVIII вв., их археологической карты и программы целенаправленного изучения. В связи с этим мы рассматриваем свою работу как своеобразное введение в современную археологию данного периода в истории полуострова. Она включает анализ правомерности 
использования термина «османская археология» применительно к Крыму, историю археологического изучения памятников Крымского ханства и Османской империи на территории полуострова и общий анализ особенностей и перспектив данного направления крымской археологии на современном этапе.

\section{О термине «османская археология» В Крыму}

Как уже отмечено, в историографии при публикации археологических материалов конца XV-XVIII вв. из раскопок памятников Крыма либо в процессе их анализа присутствует терминологическое разнообразие для обозначения данного периода в истории полуострова. Наряду с вполне ясными понятиями - «археология османского периода в истории Крылма или «позднесредневековая археология» встречаются и менее однозначные определения - «турецкая археология», «мусульманская археология» (о содержании термина: Ситдиков, Измайлов, 2016) или «археология Крылмского ханства». Как нам представляется, используемый в настоящей работе термин «османская археология», по своему содержанию, превосходит все перечисленные терминологические эквиваленты качественно, хотя и требует некоторого объяснения.

«Османская археология» как отдельное направление археологической науки сложилось относительно недавно, в 80-90-х гг. XX в., хотя ему предшествует длительный период изучения отдельных памятников исламской архитектуры и искусства на территории Европы, Северной Африки и Ближнего Востока. Она представляется областью археологии, всесторонне изучающей историю и культуру Османской империи на основе, главным образом, сохранившихся материальных источников. Помимо традиционных объектов исследований - памятников религиозного культа и художественной культуры Ислама, «османская археология» сейчас изучает и все другие возможные виды археологических памятников и вещественных источников, без акцента на их конфессиональную и этнокультурную принадлежность - города, сельские поселения, некрополи, отдельные фортификационные и гидротехнические сооружения, поля военных сражений, массовый археологический материал.

К числу важнейших особенностей «османской археологии» относятся: глобальный характер экономики и торговли Османской империи, индикаторами которой, в том числе и на уровне быта самых отдаленных провинций османского мира, являются регулярные находки в культурном слое археологических памятников предметов церемонии кофепития и табакокурения и повсеместное распространение османского фаянса и китайского фарфора (селадона); тесная связь археологических исследований с многочисленными для этого времени данными нарративных источников, результатом которой является потенциально узкая хронология культурных напластований и их определенная атрибуция историческим событиям эпохи; широкое использование материалов этнографии, прежде всего, архаичных элементов культуры Нового времени современных народов, прежде входивших в состав Османской империи, особенно на этапе интерпретации и реконструкции фрагментарных археологических источников (Baram, Carroll, 2002; Laszlovszky, Rasson, 2003).

Для изучения истории Европы, и шире всего Средиземноморского региона, «османская археология» ныне рассматривается как неотъемлемый компонент ряда более крупных направлений археологической науки:

- «средневековой археологии», изучая материальные древности завершающего этапа эпохи средневековья, начиная с конца XV в. и до середины XVII в., а для отдельных регионов - вплоть до конца XVIII в. Следует отметить, что, помимо устоявшегося в отечественной науке термина «позднесредневековая археология», для обозначения этого исторического периода в европейской и американской историографии используется и другое понятие - «постсредневековая (постмедиевальная) археология» (реже - «археология Раннего Нового времени»), особенно применительно к истории стран Западной и Центральной Европы в 1450-1750-е гг. (Bintliff, 2008);

- «исторической археологии», то есть археологии письменного периода в истории человечества или, что точнее, ее отдельных исторических периодов, связанных с крупнейшими мировыми империями, например, «римская археология», «византийская археология», «золотоордынская археология» и пр. (о ее предмете и методе см.: Lees, Burke, Orser, 2008);

- «исламской археологии», которая ныне изучает не столько архитектурные памятники и материальные предметы, связанные с исламским культом, сколько всю материальную историю регионов Европы, Африки и 
Азии периода доминирования здесь исламских политических образований и государств (Insoll, 1998, p. 1-25; Northedge, 1999).

Перечисленные составляющие «османской археологии», безусловно, свидетельствуют об оптимальности использования именно этого термина по отношению к Крыму при изучении его материальной культуры для конца XV-XVIII вв. Весь полуостров в данный исторический период был частью османского мира, независимо от того, какая из его областей находилась под контролем администрации Османской империи или управлялась Крымским ханством. Он являлся важнейшим региональным центром османского Причерноморья, где происходили процессы заимствования и переосмысления на местной почве достижений культуры и искусства Османской империи, регулярный османо-крымский товарообмен и миграции населения.

В таком историческом контексте понятие «османской археологии» применительно к истории Крыма значительно глубже терминов «турецкая археология» и «мусульманская археология», ввиду неопределенности содержания первого в современной турецкой историографии - изучение археологии Османской империи в целом (?) или все-таки деятельности ее государственных институтов в этом направлении с конца XIX в. (?) (подробнее: Çağlar, 2017), и сосредоточенности последнего, прежде всего, на исследовании материальных памятников Ислама и истории региональных исламских общин. Ему также явно уступает в географическом смысле определение «археология Крымского ханства». К тому же особенности средневековой археологической культуры крымских татар в сравнении с «османской археологией» остаются все еще не изученными, что делает выделение этого термина для обозначения самостоятельного направления археологической науки, на сегодняшний день, преждевременным.

Археологическое изучение памятников Крымского ханства и Османской империи в Крыму: основные этапы

Начальный этап научного изучения объектов «османской археологии» в Крыму связан с исследованиями памятников периода Крымского ханства на территории г. Бахчисарая в конце XIX - начале XX вв. Несмотря на свою широкую известность, они привлекли серьезное внимание лишь в связи с разрушением набережной Бахчисарайского Ханского дворца в начале лета 1892 г. и осознанием необходимости подготовки проекта реставрации бывшей резиденции крымских ханов, находившейся к этому времени в аварийном состоянии. Разработка проекта возлагалась на Императорскую Археологическую комиссию и Таврическую Ученую Архивную комиссию. Его программу фактически сформулировал Н.П. Кондаков, возглавивший специально созданную Научно-художественную комиссию: восстановление объектов, составляющих ныне историческое (средневековое) ядро Ханского дворца - портала «Демир-Капу», Зала Дивана, Летней беседки, «Фонтана слез» и «Золотого фонтана» в Фонтанном дворике, «Золотого кабинета», Малой и Большой дворцовых мечетей, медресе, дюрбе, включая их оригинальные интерьеры и росписи, и обязательность предшествующих реставрации и ремонтам археологических работ (Кондаков, 1899; об этом проекте см. также: Науменко, Герцен, Ганцев, 2020, с. 107-111).

Однако, первые раскопки позднесредневековых памятников Бахчисарая были проведены на территории заброшенного мусульманского кладбища в ущелье Ханлы-дере. В течение 1898-1899 гг. здесь были исследованы три мавзолея-дюрбе, датированных, на основании погребального обряда и монет хана Селим-Гирея (без уточнения их хронологии), периодом Крымского ханства (рис. 1) (Кирилко, 2009, с. 439-442). Из-за полной утраты дюрбе к настоящему времени уточнить их датировку, как и точное местонахождение объектов раскопок, сейчас уже не представляется возможным. Отметим в этой связи лишь недавнюю публикацию фрагментов узорной бархатной ткани XV-XVI вв. османского происхождения из одного из мавзолеев, раскопанных в Ханлыдере в 1899 г. (Теплякова, 2016).

На территории Бахчисарайского Ханского дворияа первые археологические исследования были проведены В.А. Фоминым несколько позднее, в 1902-1903 гг., в ходе разработки уже упомянутого проекта его реставрации. Места этих раскопок восстанавливаются на основании архивных материалов - в воротном проеме Главного корпуса, перед «Порталом Алевиза», в Фонтанном дворике, помещении «Казнохранилища», Зале Дивана, Бассейном и Персидском двориках, но материалы исследований, к сожалению, не сохранились (Науменко, Герцен, Ганцев, 2020, с. 111).

Несмотря на скромные результаты раскопок 1898-1899 и 1902-1903 гг., археологиче- 
ские памятники Бахчисарая с этого времени по праву входят в число наиболее важных для изучения материальной культуры Крымского полуострова в османский период его истории. Их основной перечень приведен уже в небольшой заметке У. Боданинского (Боданинский, 1917). За пределами Бахчисарая интерес к материальным древностям конца XV-XVIII вв. в это время оставался незначительным.

Качественно новый этап исследований памятников «османской археологии» на полуострове приходится на период 1924-1929 гг., когда во многом благодаря усилиям того же У.А. Боданинского была создана и вела активную деятельность комплексная экспедиция по изучению материальных древностей Крыма, связанных с историей и культурой крымских татар (о хронологии этих исследований см.: Боданинский, 1930; МИРАС-НАСЛЕДИЕ, 2016, т. 1, с. 22-53). Участие в этом проекте известных историков-востоковедов, археологов, архитекторов - И.Н. Бороздина, А.С. Башкирова, Н.Л. Эрнста, П.И. Голландского, Б.Н. Засыпкина и О.Н. Акчокраклы, обеспечило ему высокий научный уровень при проведении полевых исследований и анализе полученных результатов.

Собственно археологическая часть проекта 1924-1929 гг. была связана с раскопками двух крупных средневековых городищ Крыма Солхата (г. Старый Крым) и на плато ЧуфуmКале в восточной части г. Бахчисарая. Если в Солхате они оказались сосредоточенными на изучении ключевых архитектурно-археологических комплексов золотоордынского времени в истории городища (караван-сарая и медресе вблизи «мечети Узбека»), то на Чуфут-Кале в 1928-1929 гг. была полностью открыта центральная мечеть крепости (Боданинский, Засыпкин, 1929), построенная, как сейчас считается, в 1454-1455 гг. ханом Хаджи-Гиреем (1441-1466). Археолого-топографические исследования впервые проведены также на ряде памятников периода Золотой Орды и Крымского ханства в г. Бахчисарае - на территории поселения ЭскиЮрт и в местности Азиз в 1924 г. (Боданинский, 1927, с. 199-200; МИРАС-НАСЛЕДИЕ, 2016, т. 1, с. 27), загороднего ханского дворияа в Аилама-дере в 1928 г. (Боданинский, 1930, с. 9; МИРАС-НАСЛЕДИЕ, 2016, т. 1, с. 48) и азиза Газы-Мансур в балке Марьям-дере в 1927-1929 гг. (Акчокраклы, 1928, с. 170-172; 1929, c. 184, 186).
Несмотря на качественную фото- и графическую фиксацию выявленных в ходе раскопок объектов, методика исследований оставляла желать лучшего, полностью соответствуя требованиям своего времени. В изданных материалах практически не уделено внимания стратиграфии памятников и обнаруженному массовому археологическому материалу; все датировки обоснованы данными эпиграфики и архитектурными аналогиями. Этого, на сегодняшний день, явно недостаточно для установления точной хронологии и периодизации перечисленных археологических объектов. Пожалуй, среди всех научных работ, опубликованных по итогам проекта 1924-1929 гг., наибольшую актуальность сохраняет до настоящего времени лишь статья Б.Н. Засыпкина, первое обобщающее исследование, посвященное мусульманским архитектурным памятникам XIV-XVIII вв. на полуострове и написанное, к тому же, на материалах собственных натурных обследований автора 1926-1927 гг. (Засыпкин, 1927).

Тем не менее, трудно переоценить значение археологических и архитектурно-археологических исследований 1924-1929 гг. для современной «османской археологии» в Крыму. Они, по сути, сформировали необходимую методологию будущих работ в этом направлении, определив основной круг и разновидности археологических памятников и показав на практике необходимость междисциплинарного характера их изучения.

Следующий этап изучения памятников «османской археологии» на территории полуострова - 50-80-е гг. XX в., может быть определен как период накопления археологического материала и знаний. С учетом уже более совершенной методики ведения полевых работ на археологических памятниках, потребовавшей от исследователей изучения и фиксации всех выявленных культурных горизонтов и строительных ярусов, их основным источником становятся результаты систематических раскопок многослойных археологических объектов (городищ, крепостей) Крыма, силами крупных научных экспедиций - Мангупской (с 1967 г.), Судакской (1977-2000 гг.), Солхатской (с 1978 г.), Алустонской (1981, 1984-1995, 1998 гг.), Партенитской (1985-1988 гг.), Чуфут-Кальской (1987-1989 гг.). Главным, но объективным, недостатком таких многолетних работ на памятниках является длительное формирование источниковой базы, а также медлен- 
ное введение новых материалов в научный оборот. Показателем этого является практически полное отсутствие обобщающих исследований, за исключением небольшого очерка А.Л. Якобсона, посвященного материальной культуре Крыма XVI-XVIII вв. и основанного, как и прежде, на обзоре известных архитектурных памятников Бахчисарая (Якобсон, 1964, c. 141-148).

Другим источником формирования сведений о материальной культуре Крыма в османский период его истории оставались археологические раскопки памятников этого времени в рамках подготовки научной документации для их реставрации либо в ходе благоустроительных работ в исторической части городов полуострова. Их качество во многом зависело от условий охранных исследований и степени вовлеченности специалистов-археологов в разработку реставрационных проектов.

Примерами таких работ являются, прежде всего, археологические исследования на месте османской крепости в Керчи, в ходе реконструкции центральной площади Ленина (бывшая Предтеченская площадь) и расположенной здесь церкви св. Иоанна Предтечи в 60-80-е гг. XX в. (раскопки И.Б. Зеест и А.Л. Якобсона в 1963-1964 гг., Т.И. Макаровой в 1970-1971 гг. и В.Н. Холодкова в 1988 г.), ограниченные по площади и оставшиеся не изданными (Науменко, Пономарев, 2018, с. 354-355). Крайне низким методическим уровнем характеризуются раскопки Бахчисарайского Ханского дворца, проводившихся Е.И. Лопушинской в 1960-1962 гг. и А.Б. Авагяном в 1985-1986 гг. в рамках подготовки проекта реставрации памятника (Науменко, Герцен, Ганцев, 2020, с. 111). Пожалуй, лишь раскопки 1988 г. на месте Арабатской крепости, в ходе которых были частично исследованы морские ворота, пороховой погреб, мечеть, хамам крепости и уточнена ее историческая периодизация, могут быть оценены как по-настоящему удачные (Герцен, Колтухов, 2009, с. 149-156).

Современный период «османской археологии» в Крыму начинается в начале 90-х гг. XX в. Среди рубежных научных исследований, определивших его проблематику и методологию, необходимо, прежде всего, отметить публикации И.В. Волковым и Дж. Хэйсом в 1992 г. классифицированных керамических комплексов османского периода из раскопок крепости Азак и квартала Сарачхане в Стамбуле, которые содер- жали основные группы реперных находок XV-XVIII в. (бытовой глазурованной и неглазурованной керамики, изделий из фаянса и селадона, курительные трубки), характерные для культурных горизонтов этого времени на памятниках всего Причерноморья и Восточного Средиземноморья (Волков, 1992, с. 14-19, табл. 3; Hayes, 1992, p. 233-395). Эти работы, наряду с вышедшим позднее керамическим гидом-определителем И. Врум (Vroom, 2005, p. 140-177), сохраняют свое значение вплоть до настоящего времени, особенно в процессе практической обработки массового археологического материала. Почти одновременно издаются две монографии, посвященные истории Мангупа и Чуфут-Кале, двух крупнейших крепостей османского Крыма, основанные на результатах их археологического изучения (Герцен, 1990; Герцен, Могаричев, 1993).

Финальным этапом становления османских исследований в археологии на полуострове стало проведение в 1998 г. в г. Ялта Международной научной конференции «Поливная керамика Средиземноморья и Причерноморья X-XVIII вв.». На ней впервые предметно обсуждались вопросы атрибуции и хронологии наиболее важных керамических индикаторов археологических комплексов османского времени. Итоги этих дискуссий опубликованы в сборнике материалов конференции (Герцен, Науменко, 2005; Тесленко, 2005; Коваль, Волошинов, 2005).

К началу 2000-х гг. процесс актуализации «османской археологии» в Крыму окончательно завершился. Об этом свидетельствует резко возросшее число раскопок памятников османского периода в истории полуострова (об этом ниже). Еще одним фактором, позволяющим рассматривать данное направление археологической науки как уже сложившееся, является ряд успешных диссертационных проектов по этой проблематике, основанных, в том числе, на результатах самостоятельных археологических исследований их авторов (Бочаров, 2000; ряд диссертаций опубликованы в виде научных монографий: Руев, 2014; Ибрагимова, 2015; Белик, 2016).

Современная «османская археология» в Крыму: основные направления исследований

Наш анализ подводит итоги основных направлений археологических исследований в области «османской археологии» на полуострове за последние десятилетия. 
Он включает обзоры наиболее важных опубликованных работ, посвященных исторической топографии и материальной культуре городов и крепостей Крыма конца XV-XVIII вв., археологии поселений, некрополей и «полей военных сражений», а также архитектурно-археологическим и вещеведческим исследованиям на памятниках этого времени (рис. 2).

Историческая топография крепостей Османской империи и городов Крымского ханства на Крымском полуострове. Данное направление «османской археологии» в Крыму пока еще имеет историко-археологический характер. Реконструкция размеров, планировки и архитектурно-топографических доминант городов и крепостей Крыма, входивших с 1475 г. в состав санджака Кефе Османской империи, повышенного в 1568 г. до статуса одноименного эйялета, либо расположенных на территории Крымского ханства, основана, главным образом, на имеющихся сведениях письменных и картографических источников, с редкой информацией о результатах раскопок отдельных археологических объектов.

На сегодняшний день, такого рода исследования выполнены для большинства османских крепостей на территории Крымского полуострова - Кефе (Бочаров, 2000, с. 6-7, 14-19; Бочаров, 2016a), Мангупа (Бочаров, 2008; Герцен, Науменко, 2019, с. 124-134, 160-162), Судака (Майко, Джанов, 2016), Балаклавы (рис. 3) (Бочаров, 2019), Керчи (Бочаров, 2005; Науменко, Пономарев, 2018), Ени-Кале и Арабата (Герцен, Колтухов, 2009; Белик, 2016, с. 57-107). Единственным исключением остается крепость Инкерман.

Историческая топография городов Крымского ханства, в основном, для периода XVII-XVIII вв., восстанавливается для Бахчисарая (Бочаров, Сейтумеров, 2017), Ак-Мечети (рис. 4) (Бочаров, 2015) и в самом общем виде для Кырк-Ера (Чуфут-Кале) (Герцен, Могаричев, 2016а, с. 30-34, 189-240) и Гезлева (Кутайсов, Кутайсова, 2007, с. 42-60). Сведения о других региональных городских центрах, находившихся под юрисдикцией крымских ханов - Карасубазаре, Эски-Крыме (Старом Крыме) и Ор-Капу (Перекопская крепость), по-прежнему не систематизированы.

Из изучения исторической топографии крепостей и городов Крыма конца XV-XVIII вв. следует ряд важных заключений общего характера:
- Для большинства крепостей Османской империи на территории полуострова, за исключением слабо исследованного Инкермана и построенных в начале XVIII в. Арабата и Ени-Кале, характерна топографическая преемствованность с существовавшими ранее на их месте планиграфическими структурами. Она выражается, прежде всего, в сохранении конфигурации линий оборонительных стен XIV-XV в. и общей композиции крепостей: цитадель - основная (внешняя) линия обороны - неукрепленное предместье. Новые фортификационные элементы - валганги, гласисы, значительное утолщение стен и др., отражают принципы военного дела эпохи, связанной с широким применением огнестрельного оружия;

- Несмотря на различное происхождение городов и крепостей Крыма, для них характерен иррегулярный тип внутрикрепостной (внутригородской) застройки, основными элементами которой становятся замкнутые жилые кварталы (махалле), разветвленная сеть центральных улиц и переулков и новые архитектурно-топографические доминанты - мечети, медресе, караван-сараи, рыночные площади и др. На свободных пространствах городской территории или на ее окраинах функционировали некрополи. Прямой преемственности между застройкой XVI-XVIII вв. и более раннего времени не было, даже если речь идет об османских крепостях Южного и Восточного Крыма. Позднесредневековые строительные ярусы возводились поверх прежней, уже руинированной застройки, с использованием последней в качестве «каменоломен» для добычи строительного материала;

- Важнейшей частью городской жизни является функционирование системы этноконфессиональных кварталов (мусульманских, христианских, иудейских и др.) на территории крупных городов и крепостей, независимо от их политико-административного подчинения.

Археология османских крепостей Крыма. Археологически крепости Османской империи на территории полуострова изучены крайне неравномерно. Исследования ЕниКале никогда не проводились, за исключением небольших разведок 2008 г. (рис. 2: 2) (Белик, 2016 , с. 14). Слабо опубликованы эпизодические раскопки на территории КаффыКефе (рис. 2: 5) (Айбабина, Бочаров, 1998, с. 195-199, рис. 1; 2,1-2), Керчи (рис. 2: 1) 
(сведения о них систематизированы: Науменко, Пономарев, 2018, с. 353-356), Арабатской крепости (рис. 2: 3) (Герцен, Колтухов, 2009) и Инкермана (рис. 2: 7) (Веймарн, 1963; Филиппенко, 1996). Лишь для истории османского Мангупа, Балаклавы и, в какой-то степени, Судака результаты систематических археологических исследований последних десятилетий уже играют значительную роль.

Мангуn (рис. 2: 6). Среди всех османских крепостей Крыма Мангупское городище является наиболее изученным как с точки зрения систематизации нарративных источников по его истории для периода конца XV-XVIII вв. (Бочаров, 2008; Герцен, Науменко, 2019, с. 124-132, 159-164), так и в археологическом плане (рис. 5). Справедливо считается, что после завоевания османской армией в 1475 г. крепость была реконструирована (не позднее 1504 г.) и стала центром одного из кадылыков санджака Кефе. Тогда же здесь появился османский гарнизон. Одной из важных особенностей топографии Мангупа этого времени является проживание на городище в XVI - начале XVII вв. нескольких этноконфессиональных общин - мусульманской, христианской и иудейской. Статус главного форпоста Османской империи в горной части Крыма крепость сохранила до 1774 г., когда, по условиям Кучук-Кайнарджийского мира, турецкие воинские подразделения покинули полуостров.

Благодаря обширным размерам поселения конца XV-XVIII вв. на Мангупе его изучение началось уже с момента первых раскопок городища в середине XIX в. Важным этапом являются исследования оборонительной системы памятника в 1970-1980-е гг. Итоги этих работ подведены в монографии А.Г. Герцена 1990 г., в которой отмечены, в том числе, ключевые события истории и особенности фортификации Мангупского городища для периода 1475-1774 гг.: многочисленные следы осады и штурма крепости в 1475 г., особенно на северном направлении военных действий; значительный объем ремонтов и перестроек конца XV - начала XVI вв. на отдельных фортификационных узлах крепостного полигона; сохранение турками вплоть до 1774 г. композиции оборонительной системы крепости, сложившейся еще в период княжества Феодоро и состоявшей из трех укрепленных линий - Главной (Внешней), Второй (Внутренней) и цитадели на мысе Тешкли-бурун (Герцен, 1990, с. 122-123,
129, 141, 144, 147-155). Необходимо подчеркнуть, что большинство из этих заключений стали основой для дальнейших археологических исследований османского Мангупа. С начала 90-х гг. XX в. такие раскопки приобрели систематический характер и затронули практически все известные архитектурнотопографические доминанты городища для XVI-XVIII вв.

Изучение системы обороны Мангупского городища в османский период его истории остается традиционным направлением археологического изучения памятника и в последние десятилетия. Благодаря разведкам и раскопкам периода 1997-2013 гг. установлены новые подробности событий 1475 г. Выяснено, что, помимо северного направления штурма Мангупа, театр боевых действий включал также попытки осаждавших прорвать южную линию обороны крепости, в районе укрепления A.XVII. Исследованиями зафиксированы неизвестные ранее объекты османской военно-полевой фортификации - артиллерийских позиций в балке Гамам-дере и на холме Мазар-тепе, боевых площадок для штурмовых групп в балке Гамам-дере; выдвинута гипотеза о расположении полевого лагеря османской армии на месте д. Адым-Чокрак; систематизированы данные об основных видах османского наступательного вооружения (пушечных ядрах, наконечниках стрел, пулях от ручного огнестрельного оружия) (Герцен, 2001; Герцен, Руев, 2008; Руев, 2014, c. $34-56,187-262)$.

Другим направлением исследований является изучение исторической топографии Мангупа XVI-XVIII вв. посредством раскопок основных архитектурно-археологических комплексов этого времени.

Для изучения материальной культуры Мангупа периода XVI - начала XVII вв., когда крепость функционировала в своих максимальных размерах, эталонным археологическим объектом является участок застройки у тыльной стороны Мангупской цитадели, где в 1970-1971 и 1990-2005 гг. на площади раскопа около 2 тыс. кв. м открыты 11 каменных жилых зданий (рис. 6). Иррегулярная планировка этого квартала, с различной ориентацией сооружений, отличается высокой степенью плотности. Отсутствуют какие-либо примеры преемственности этой застройки с предшествующим ей кварталом XV в. Из материалов исследований опубликованы результаты раскопок октагонального 
храма, перестроенного в османское время в мусульманскую мечеть (Герцен, Науменко, 2010), участка строительных сбросов на склонах мыса Тешкли-бурун (Герцен, Землякова, Науменко, Смокотина, 2006, с. 374-392), а также показательные находки глазурованной керамики (Герцен, Науменко, 2005, с. 263-264, рис. 18-23), свинцовых пуль и пулелеек (Герцен, Руев, 2008, с. 393-394, 398-399, рис. 13-15).

Жилому кварталу у тыльной стороны Мангупской цитадели синхронны по времени функционирования два наиболее поздних христианских храма в восточной части городища - церкви св. Константина и св. Георгия, которые продолжали использоваться как квартальные храмы местной христианской общины вплоть до конца XVI - начала XVII вв. (Герцен, Науменко, 2015б; Герцен, Науменко, 2017а, с. 56-108; Герцен, Науменко, 2018). Скорее всего, в правление султана Баязида II (1481-1512) на эспланаде цитадели построена до сих пор еще археологически не исследованная Главная (Джами; Camii-i Şerif) мечеть крепости. Она известна по данным письменных источников и хорошо локализована на местности (Герцен, Науменко, 2019, с. 160). Не позднее второй половины XVI в. в западной части городища, где уже сформировался иудейский (раббанитско-караимский) жилой квартал, сооружается здание синагоги-кенассы (Герцен, Науменко, 2017б, с. 23). Судя по нумизматическому комплексу находок из раскопок Мангупского дворца 1425-1475 гг., возведенный на его руинах участок османской застройки наиболее активно функционировал именно в период конца XV - начала XVII вв. (Душенко, 2020, с. 95-96).

C начала XVII в. общая интенсивность жизни поселения на Мангупе постепенно снижается: в связи с резким сокращением численности греко-православной общины забрасываются церкви св. Константина и св. Георгия; немногочисленны сооружения и находки XVII-XVIII вв. на территории цитадели и дворца (Герцен, Науменко, 2015a, с. 96; Герцен, Науменко, Душенко, 2018, с. 57-58); функционируют лишь участки застройки в верховьях балок Гамам-дере и Табана-дере, где проживают соответственно мусульманская и караимская общины крепости. Наиболее показательные комплексы второй половины XVII - начала XVIII вв. выявлены в ходе раскопок жилого квартала в районе церкви св. Константина (Герцен, Иванова, Наумен- ко, Смокотина, 2007) и на месте «городской свалки» вблизи синагоги-кенассы (Герцен, Науменко, 2015а, с. 96).

Особым направлением исследований позднесредневекового Мангупа является археолого-эпиграфическое изучение караимского некрополя в балке Табана-дере. Современные раскопки памятника проводились в 1985-1986 и 1991 гг. Они показали поздний характер его появления - не ранее середины XV в., и использование ущелья Табана-дере в более раннее время исключительно в качестве сельскохозяйственной территории Мангупского городища (Герцен, 2003, с. 72-73). В 19902010 гг. могильник был подвергнут детальному эпиграфическому обследованию. На сегодняшний день общее количество выявленных надгробий караимского кладбища в Табанадере составляет 1008 единиц, эпиграфический корпус - 228 надписи с общей датой в пределах 40-х гг. XV - 70-х гг. XVIII вв. Этот период, очевидно, соотносится со временем существования некрополя (Кашовская, 2017).

Судак (рис. 2: 4). Несмотря на многолетние исследования, общие представления о памятнике как одном из центров османского присутствия на Крымском полуострове по данным археологии, остаются крайне противоречивыми. Прежде всего, данное заключение имеет отношение к Судакской крепости, где располагался османский гарнизон в конце XV-XVIII вв. Многие высказанные в историографии положения о характере ее оборонительной системы и внутрикрепостной застройки в это время - об отсутствии следов штурма 1475 г. (Руев, 2014, с. 175-179), слабости крепостных сооружений или об использовании жилых зданий XIV-XV вв. обитателями крепости в последующие столетия (Майко, Джанов, 2016, с. 16-18), рассматриваются нами лишь в качестве гипотезы, правомерность которой можно проверить только в ходе будущих раскопок.

По результатам исследований Судакской крепости, обоснованным представляется вывод о сохранении после 1475 г. Османской империей общей композиции и планировки генуэзской системы фортификационных укреплений. Предложенная в свое время И.А. Барановым датировка возведения барбакана крепости не ранее XVII в. ныне пересмотрена в пользу 1469 г., на основе зафиксированной здесь стратиграфической ситуации и закладной плиты с именем консула Бернардо ди Амико (Майко, Джанов, 2015, с. 311-312; 
ср.: Баранов, 1988, с. 90-96). Жилая застройка османского времени выявлена на различных участках крепостного полигона - на территории цитадели, у тыльной стороны куртины XV (Майко, Джанов, 2015, с. 286, 320, рис. 152; $196 ; 197,1-3)$ и на месте центрального городского квартала, вблизи католического храма «Девы Марии (Тур, 2008, с. 353-355). Археологически локализованы две важные архитектурно-топографические доминанты крепости этого времени - мечеть Падеша-Джами (Джанов, 2005) и мечеть Хаджи-бея (Майко, Джанов, 2016, с. 33-40). К сожалению, для всех перечисленных памятников характерна общая проблема - отсутствие полной публикации результатов исследований, в том числе рисунков и статических таблиц массового археологического материала (находок керамики, изделий из металла и пр.); изданы лишь отдельные планы, архитектурные и стратиграфические разрезы открытых сооружений.

Совершенно иная ситуация складывается в ходе археологического изучения предместья Судакской крепости, особенно для кварталов в портовой части городища. Здесь, начиная с 2006 г., на площади раскопов VI, VII и VIII выявлена серия каменных построек османского периода, датированных в пределах конца XV - начала XVII вв. (Майко, Джанов, 2015, с. 234-237, рис. 108, 119-12). Материалы исследований свидетельствуют об общей преемственности яруса застройки c планировкой предшествующих строений средневизантийского и генуэзского времени. Археологические комплексы из заполнения зданий, а также из так называемого городского «зольника», дают достаточно полное представление о материальной культуре, быте и торговых связях населения османского Судака (Алядинова, 2012; Алядинова, Тесленко, Майко, 2015; Тесленко, Майко, 2020).

Балаклава (рис. 2: 8). Для изучения истории крепости периода 1475-1771 гг. археологические исследования, которые ведутся систематически с конца 90-х гг. ХХ в., сейчас уже имеют первостепенное значение. Их промежуточные результаты изданы в виде обзорных статей либо сокращенных вариантов научных отчетов об этих раскопках (Адаксина, Мыц, Ушаков, 2012; Адаксина, Мыц, 2017; Дьячков, 2019). Качество выполненных работ не вызывает особых сомнений. Необходимы лишь подробные публикации отдельных археологических комплексов и массового вещественного материала для проведения более детального анализа материальной культуры памятника. В связи с этим акцентируем внимание лишь на некоторых общих выводах применительно к истории османской Балаклавы, которые основываются на данных ее современных археологических исследований.

Прежде всего, установлен факт наличия штурма крепости во время военной кампании 1475 г., о чем свидетельствуют следы пожара этого времени, выявленные в ходе раскопок так называемой башни «Барнабо Грилло» (№1) (Мыц, 2009, с. 479-480), помещений №№2 и 3 многокамерного жилого здания к западу от армянской церкви с притвором (храма №5) (Адаксина, Алексеенко, Гинькут, Мыц, 2018, c. $10-23,41)$ и вблизи башни №8 Консульского замка на нижней вершине г. Кастрон, где в 2007 г. раскопана сожженная площадка для камнеметного орудия типа «требюше» (Дьячков, 2019, с. 784-786). Несмотря на локальный характер данных археологических комплексов, они в целом свидетельствуют об оказанном генуэзским гарнизоном ожесточенном сопротивлении османской армии, что осталось не известным письменным источникам.

Другим объективным заключением, следующим из материалов раскопок, является вывод об использовании османским гарнизоном фортификационных сооружений 1420-1470-х гг. вплоть до конца XVIII в. (Адаксина, Мыц, 2017, с. 131). Конечно, это наблюдение не исключает ремонтов и перестроек отдельных оборонительных узлов на протяжении указанного периода времени. К примеру, как фортификационный комплекс перестал функционировать уже упоминавшийся Консульский замок, где на месте башни №8 и вокруг нее возводятся новые жилые и хозяйственные сооружения (Дьячков, 2019, с. 779-784, рис. 8-12). Только лишь как арсенал для хранения военной амуниции и цистерна используется башня №5 у подножия замка св. Николая (Адаксина, Алексеенко, Гинькут, Мыц, 2018, с. 24-39, 41-43; Алексеенко, Дьячков, Неделькин, Ступко, 2019, с. 39-40). В первой трети XVIII в., в связи с ростом военной угрозы со стороны Российской империи, внутри барбакана башни «Барнабо Грилло» появляется валганг, предназначенный для пушечной батареи (Мыц, 2009, с. 479; Адаксина, Мыц, 2017, с. 131, 139).

Наконец, проведенные археологические исследования, безусловно, свидетельствуют о сохранении, по крайней мере, до середины 
XVII в., плотной, террасного типа, внутрикрепостной застройки османской Балаклавы, архитектурно-топографическими доминантами которой, в том числе, продолжали оставаться христианские храмы. К числу таковых следует отнести так называемую «консульскую церковь» на территории одноименного замка в западной части крепости, восстановленную после событий 1475 г. (Дьячков, 2019, c. 774-777). Еще одним неординарным храмом османского периода является раскопанная в 2014-2015 гг. армянская церковь с гавитом в центральной части городища, которая функционировала до конца XVIII в. (Адаксина, Мыц, 2016, с. 7-26; Бочаров, 2019, с. 322).

Археология городов Крымского ханства. Данное направление «османской археологии» в Крыму остается, прежде всего, археологией столицы Крымского ханства - города Бахчисарая (рис. 2: 9). Об исследованиях других городских центров региона - Гезлева, Карасубазара, Ак-Мечети, Ор-Капу, Эски-Крыма (рис. 2: 11-15), информации крайне мало. В то же время, говоря о современной археологии Бахчисарая, важно подчеркнуть, что и в данном случае речь также идет не столько о целенаправленном изучении стратиграфии и исторической планиграфии города, сколько о серии разновременных и разноплановых раскопок отдельных его памятников, имеющих разную степень изученности и опубликованности.

Бахчисарайский Ханский дворец. Особенностью археологии дворца на протяжении XX - начала XXI вв. является ее традиционно тесная связь с проектами реставрации и благоустройства территории памятника. Из-за этого раскопки практически всегда имели ограниченную площадь исследований, а их результаты долгое время оставались незначительными, что приводило к несколько искаженным представлениям о Бахчисарайском дворце как исключительно объекте архитектуры. Между тем, именно данные археологии являются решающими для реконструкции планиграфии дворца в средневековый период его истории. Одним из ключевых вопросов раскопок является решение археологическими методами проблемы точного времени строительства, как принято считать, наиболее ранних (XVI-XVII вв.) сооружений комплекca - Зала Дивана, Малой и Большой дворцовой мечетей, бани Сары-Гюзель (об истории археологического изучения дворца: Науменко, Герцен, Ганцев, 2020, с. 105-113).
Начало современного этапа археологического изучения Ханского дворца связано с масштабными раскопками А.М. Ибрагимовой в 2000-2011 г. В разные годы ею были исследованы объекты на территории Гаремного, Бассейного, Персидского двориков, вблизи Малой и Большой мечетей, бани Сары-Гюзель и дюрбе Диляры-Бикеч. Результаты работ изложены в монографии, в которой автор попытался представить собственную строительную периодизацию памятника, датируя многие из открытых сооружений периодом Крымского ханства (Ибрагимова, 2015, с. 190-217, 251-276). К сожалению, знакомство с книгой показывает необоснованность большей части представленных в ней выводов, общее низкое качество ведения раскопок и слабый уровень публикации их результатов.

Объективную стратиграфию Бахчисарайского дворца удалось выяснить лишь во время недавних раскопок памятника в 2017 г. и особенно 2018-2019 гг., проводившихся под руководством А.Г. Герцена. Последние работы выполнялись в пределах 29 археологических квадратов, заложенных вблизи зданий Главного, Библиотечного, Конюшенного, Гаремного, Свитского корпусов, Соколиной башни, Малой дворцовой мечети, в Бассейном, Гаремном, Кухонном двориках, вдоль дворцовой набережной и у оснований каменных мостов через р. ЧурукСу (Рис. 7). Таким образом, ими было охвачено около 70\% современной территории дворца, за исключением его северо-восточного участка (Большой Ханской мечети, мезарлыка и бани Сары-Гюзель). Стратиграфия дворца, по итогам этих раскопок, включает культурные горизонты и археологические комплексы, сформировавшиеся во второй половине XVI - первой половине XVII вв., в конце XVII - начале XVIII вв. (до и в результате «пожара» 1736 г.), в 1740-1760-е гг. и в третьей четверти XVIII в. (до первого ремонта 1784-1787 гг.), в 1820-1830-е гг. (период «ремонтов» И.Ф. Колодина и Ф.Ф. Эльсона) и во время реконструкции дворцовой набережной в 1894-1915 гг. Подтвердился факт отсутствия каких-либо поселенческих структур на месте дворца до начала его строительства ханом Сахиб-Гиреем I (1532-1551) (Науменко, Герцен, Ганцев, 2020, с. 113-116). Необходимо отметить и другой значимый результат проведенных исследований - обилие хорошо стратифицированных археологических комплексов, с узкой датой формирова- 
ния и насыщенных разнообразными предметами быта XVI-XVIII вв. (рис. 8-11). Данное заключение нам представляется чрезвычайно важным с учетом общей слабой опубликованности массового археологического материала из прежних раскопок памятника (Коваль, Волошинов, 2005; Ибрагимова, 2015, с. 257-278; Гусач, Моисеев, 2017].

Эски-дюрбе и мавзолеи Азиза. Городская застройка Бахчисарая позднесредневекового периода археологически практически не изучена. Датировка ряда сохранившихся мечетей «Старого» города - Тохталы-Джами, Орта-Джами, Молла-Мустафа, которые считаются в литературе ее архитектурно-топографическими доминантами (Зиливинская, 2020, c. 70), не подтверждена результатами архитектурно-археологических исследований памятников и поэтому носит исключительно гипотетический характер. Не меньше разночтений вызывает хронология и культурная атрибуция дюрбе-мавзолеев на территории Бахчисарая, расположенных в относительной близости от Ханского дворца (Эски-дюрбе и мавзолеи в Ханлы-дере) и в его западной части, в местности Азиз (рис. 2, 17) (Боданинский, 1927, c. 196-200; Засыпкин, 1927, с. 116-124). Главная проблема современной дискуссии касается интерпретации результатов недавних раскопок двух, вероятно, наиболее ранних мавзолеев из этой группы - Эски-дюрбе и дюрбе Мухаммед-Шах-бея. Остальные памятники либо не сохранились (дюрбе в Ханлы-дере), либо остаются археологически не изученными.

Материалы архитектурно-археологических исследований дюрбе Мухаммед-Шахбея в 1991 г. опубликованы В.П. Кирилко. На основании стратиграфических наблюдений и монеты крымского хана Шагин-Гирея (1777-1783) 1778 г. выпуска из «строительного горизонта» здания автор работы датирует его возведение последней четвертью XVIII в., что противоречит традиционной (золотоордынского времени; в пределах XIV - начала $\mathrm{XV}$ вв.) хронологии памятника в историографии (Кирилко, 2009, с. 451-464). По мнению Э.Д. Зиливинской, результаты раскопок свидетельствуют не о поздней дате сооружения комплекса, но, скорее, о его длительном, вплоть до конца XVIII в., использовании; архитектоника мавзолея следует типично сельджукской традиции и не соответствует особенностям архитектуры Крымско- го ханства (Зиливинская, 2014, с. 134-135). С этим замечанием, вероятно, следует согласиться.

В 2013 г. небольшие работы выполнены Э.И. Сейдалиевым на территории мавзолея Эски-дюрбе. В предварительной публикации сообщается о разновременности сооружения здания дюрбе и его южного «дворика» и находках XVI-XVIII вв., в том числе монеты Мехмед-Гирея III (1623-1628), из культурных напластований, связанных со строительством и функционированием культового комплекса (Науменко, Сейдалиев, Сейдалиева, 2016, с. 236). Однако, исследования памятника следует признать все-таки не завершенными.

Чуфут-Кале (рис. 2: 10). Раскопки крепости, начатые еще в 20-е гг. XX в., к сожалению, никогда не носили систематического характера. Последний период исследований относится к 1987-2004 гг., когда археологическими работами оказались затронуты многие архитектурно-топографические доминанты Чуфут-Кале - Восточная оборонительная стена (раскопки А.Г. Герцена и Ю.М. Могаричева; 1987-1988 гг.), жилая застройка в «старой» части городища (А.О. Добролюбский; 1991 г.), укрепление Пенджере-Исар (А.В. Белый и С.В. Карлов; 2000 г.), застройка вокруг дюрбе Джанике-ханым и колодец Тик-Кую (В.В. Майко, 2001-2002 гг.), «домик смотрителя» Караимского кладбища (В.И. Баранов; 2003-2004 гг.) (Исторический атлас, 2015, с. 12). Большая часть материалов этих раскопок остается еще не известной. Полноценно опубликован лишь так называемый «Кырк-Ерский клад» длительного накопления, состоящий из 4287 медных, серебряных и золотых монет XIV-XV вв. различного происхождения (Венеция, Генуэзская Каффа, Золотая Орда, Византия, Трапезунд, Молдавия, Рязанское княжество) и обнаруженный в культурном слое вокруг колодца Тик-Кую. Датировка времени сокрытия клада справедливо определяется серединой 1470-х гг., до событий 1475 г. (Майко, 2007, с. 3-9, 181). Также изданы основные результаты раскопок у тыльной стороны Восточной оборонительной стены. Они позволили сделать вывод о сооружении стены в первой половине XVI в. и нескольких более поздних строительных периодах в ее истории (Герцен, Могаричев, 2001; Герцен, Могаричев, 2016, с. 198-218).

Салачик и памятники Марьям-дере и Аилама-дере (рис. 2: 16). В Салачи- 
ке, по крайней мере, со второй половины XV в. существовало постоянное поселение, в центральной части которого ханом МенглиГиреем I (1467-1515) был возведен дворцовый ансамбль, от которого сейчас сохранились так называемое «дюрбе Хаджи-Гирея» (1501г.), Зынджырлы-медресе (1500г.), руины мечети и хамам. Масштабные археологические исследования комплекса построек Салачика были предприняты в 2006-2010 гг. А.М. Ибрагимовой в рамках реставрационного проекта. В ходе работ полностью раскопаны здания Зынджырлы-медресе и дюрбе; исследованы до уровня пола остатки хамам. Беспрецедентным открытием стал нетронутый характер гробницы в нижней части дюрбе, в которой выявлены 18 мусульманских захоронений в гробах, принадлежащих членам ханской династии. К сожалению, опубликованы лишь результаты архитектурного и естественнонаучного изучения «дюрбе Хаджи-Гирея» (Гаврилюк, Ибрагимова, 2010). Материалы археологической части проекта, в первую очередь, касающиеся Зынджырлы-медресе и хамам (планы и стратиграфические разрезы раскопов, графические и статистические таблицы вещественных находок), до сих пор не изданы и, вероятно, уже не существуют. В 2012-2013 гг. Э.И. Сейдалиев попытался восстановить стратиграфию поселения в Салачике. На глубине 1,70-2,00 м от уровня современной поверхности ему удалось выявить горизонт с мощением середины второй половины XV в. Однако, эти раскопки также остались не завершенными (Науменко, Сейдалиев, Сейдалиева, 2016, с. 235).

Единственным археологическим объектом в ущелье Ашлама-дере к северу от ЧуфутКальского плато являются руины загородного ханского дворца XVII-XVIII вв., открытого, как уже говорилось, У.А. Боданинским В 1928 г. В 2015-2016 гг. на месте предполагаемого дворцового комплекса проведены комплексные геофизические и археологические исследования. Составлена магнитометрическая карта памятника, дополненная раскопками наиболее перспективных с точки зрения археологии объектов на площади 34 кв. м. По мнению авторов работ, разобранный еще в конце XVIII в. дворец удалось локализовать на местности (Бочаров, Ситдиков, Бездудный, 2017).

Археологические исследования позднесредневековых памятников в балке Марьям-дере, ограничивающей с юга плато
Чуфут-Кале, известны только для периода 2006-2012 гг. В 2006 г. Т.А. Бобровским и Е.Е. Чуевой проведены спелео-археологические обследования скальных сооружений на северном склоне ущелья (Бобровский, Чуева, 2008). Небольшие раскопки на территории поселения Мариамполь в центральной части балки, осуществлены в 2009-2012 гг. В.И. Барановым и С.В. Карловым. На площади раскопа выявлена, как считают исследователи, общая стратиграфия памятника, которая включает культурные горизонты от эпохи раннего железного века и вплоть до конца XVIII в. (Баранов, Карлов, 2013).

Археология поселений. Необходимость археологических исследований многочисленных позднесредневековых сельских поселений на территории Крыма, известных по данным нарративных и картографических источников, уже неоднократно отмечалась в литературе. Их изучение должно быть ориентировано на получение объективной информации о размерах, особенностях планировки, домостроительства, хозяйственной инфраструктуры, гидротехнических сооружений таких населенных пунктов, а также занятиях местного населения. При интерпретации результатов раскопок широко могут быть использованы сведения письменных документов XVI-XVIII вв. и более поздние данные этнографии (Галенко, 2004).

Однако, на сегодняшний день, данное направление «османской археологии» на полуострове все еще находится на стадии формирования своей источниковой базы. Среди неукрепленных поселений Южного берега Крыма археологически изучалась лишь османская застройка Партенита (рис. 2: 22) (Алядинова, 2015) и отдельные строительные и хозяйственные комплексы этого времени на месте генуэзской крепости в Алуште (рис. 2: 21) (Алядинова, Тесленко, 2015). До недавнего времени археологически почти не изученными оставались сельские поселения на территории Крымского ханства, за исключением небольших разведок на территории так называемого «городища СарымамбашКермен» (рис. 2: 18) (Мыц, 2018). Лишь в ходе масштабных инфраструктурных проектов на территории Республики Крым 2015-2018 гг. раскопана серия крупных позднесредневековых поселений в восточной и юго-восточной частях полуострова: Биели, Кегенез Восточное, Су-Баш, Кош-Кую, Батальное 1, Батальное Западное и др. (рис. 2: 24-33). Однако, 
результаты этих работ пока еще полноценно не опубликованы.

Архитектурная археология. Данное направление археологической науки, как известно, сосредоточено на изучении памятников монументальной архитектуры с широким применением археологических методов. На практике, как правило, речь идет об исследованиях архитектурно-археологических объектов с сохранившимися крупными объемами зданий, вплоть до их перекрытий. Применительно к «османской археологии» Крыма архитектурная археология изучает сохранившиеся на полуострове крупные фортификационные, дворцовые, общественные (караван-сараи, рынки, медресе, хамам) и религиозные (мечети, дюрбе-мавзолеи, текие) комплексы. В таком случае многие из перечисленных выше исследований раскопки Ханского дворца, дюрбе МухаммедШах-бея и Хаджи-Гирея в Бахчисарае, мечети Падеша-Джами в Судаке, Арабатской крепости, церкви св. Иоанна Предтечи в Керчи, могут быть с уверенностью причислены к категории архитектурно-археологических.

Отметим еще два надежных примера архитектурной археологии для османского Крыма. Прежде всего, речь идет о работах на мечети в с. Пионерском (Эски-Сарай) в 1991 г., позволившие датировать ее в пределах начала - первой половины XVIII в. (рис. 2: 19) (Кирилко, 2012). Другим примером архитектурно-археологических исследований является однокупольная мечеть в с. Давыдово (Шейх-Кой) (рис. 2: 20). Историко-архивные и натурные обследования памятника, выполненные С.Г. Бочаровым и В.П. Кирилко, позволили им датировать его в пределах XVI-XVII вв. Важным является заключение авторов об использовании при возведении здания в качестве сполий михраба и портала со строительной надписью 1358 г., перемещенных из более ранней мечети золотоордынского времени, до сих пор не локализованной (Бочаров, Кирилко, 2016; Кирилко, 2016). Дальнейшее изучение памятника во многом зависит от его качественных раскопок. Небольшие шурфовочные работы 2018 г., доведенные до уровня полов мечети, к таковым, безусловно, не относятся (Лавров, 2019).

Археология погребений. Предполагает детальное изучение погребального обряда населения Крыма в конце XV-XVIII вв., мусульманского и иных конфессий, по данным раскопок рядовых и элитных некрополей. Необходимо сформулировать и более сложные задачи таких исследований: реконструкция сакральной топографии местности; типологическая, иконографическая и эпиграфическая интерпретация надгробных памятников; изучение организации пространства кладбищ; социокультурная характеристика населения. Для решения последней задачи большое значение имеют данные антропологии, поскольку они зачастую составляют основной комплекс сведений при раскопках могильников. Антропологический анализ способен установить не только половозрастной состав погребенных, но и предположить систему их питания, род занятий, социальный статус, полученные при жизни травмы, причины смерти и пр.

Безусловно, одним из главных открытий последних десятилетий является, как уже отмечалось, нетронутый характер гробницы в нижней части «дюрбе ХаджиГирея» в Салачике (Бахчисарай) (рис. 2 :34). В 2007-2008 гг. здесь были исследованы 18 захоронений, принадлежащих представителям ханской династии Крымского ханства. Bce они совершены по мусульманскому погребальному обряду: в вытянутом положении на спине, головой на запад; в саванах и дощатых гробах-табутах, с подушками и одеялами; табуты, установленные на железные или каменные подставки, покрыты богато орнаментированными тканями. Из погребения №8, одного из ранних захоронений мавзолея, происходит важная датирующая находка - монета Менгли-Гирея I (1467-1515) 1513 г. выпуска. По мнению Н.А. Гаврилюк, в дюрбе похоронены, вместе с первыми правителями Крымского ханства (Хаджи-Гиреем и МенглиГиреем I) и другие члены династии Гиреев для периода 1466-1551 гг. (Гаврилюк, Ибрагимова, 2010, с. 66-94).

Единственным рядовым мусульманским некрополем интересующего нас периода времени, раскопанным на широкой площади и полностью изданным, является могильник у п. Заозерное в Северо-Западном Крыму, на территории античного курганного некрополя городища «Чайка» (рис. 2: 35). Памятник исследовался в 1969-1971 гг. Изучено 46 безынвентарных погребений по мусульманскому погребальному обряду: вытянутые трупоположения на спине, головой на запад и лицом на юг (в сторону кыблы); захоронения совершены в прямоугольных ямах, либо в ямах с заплечиками, подбоями 
или уступами в их северной стенке; сверху могилы перекрыты дощатыми деревянными конструкциями и заложены камнями. Некрополь датируется, скорее всего, второй половиной XVII-XVIII вв., хотя радиоуглеродная дата костных останков еще более поздняя второй половины XVIII - первой половины XIX вв. По мнению С.Г. Бочарова, могильник принадлежал ногайскому населению региона (Бочаров, 2016б).

В последнее время, благодаря строительству автомобильной трассы «Таврида», число археологически изученных мусульманских некрополей XVI-XVIII вв. значительно возросло. Даже предварительные публикации результатов их исследований вызывают большой интерес в связи со значительным объемом и разнообразием информации. Среди изданных материалов наибольший интерес вызывает могильники Живописное и особенно Су-Баш в Юго-Восточном Крыму (рис. 2: 36-37). На площади раскопок последнего изучено 1005 погребальных сооружений, в основном безынвентарных, свидетельствующих об общей полиморфности погребальной обрядности и, соответственно, неоднородности оставившего его населения. К числу наиболее важных особенностей погребального обряда некрополя уже сейчас можно отнести: наличие трупоположений на спине, с согнутыми в коленях и разведенными в стороны ногами («поза всадника»); присутствие среди погребальных конструкций могил, обложенных кладкой из сырцовых блоков; погребения людей двух антропологических типов, с признаками монголоидности и европеодности; преобладание среди погребенных мужчин, в том числе в возрасте свыше 50 лет и с признаками тяжелых физических нагрузок на опорно-двигательный аппарат; высокую детскую и женскую (до 20-25 лет) смертность (Мастыкова, Решетова, Чаукин, Ганичев, 2019, с. 104-114).

Особенности

позднесредневекового христианского погребального обряда никогда в историографии специально не изучались, хотя археологического материала для такого рода исследований накоплено достаточно. Среди известных позднесредневековых христианских могильников на Южном берегу Крыма изданы лишь материалы исследований храмово-погребального комплекса XIV-XVIII вв. у с. Малый Маяк (БиюкЛамбат) (рис. 2: 38). Основной тип поздне-средневековых погребальных конструк- ций - прямоугольные ямы с каменной обкладкой, перекрытые плитами (Тесленко, Лысенко, 2004). Для памятников Горного Крыма опубликованы результаты исследований двух могильников второй половины XVII-XVIII вв. (до 1778 г.) у сел Богатырь и Прохладное в Бахчисарайском районе (рис. 2: 39-40). Зафиксирован, вероятно, типичный погребальный обряд для христиан региона этого времени - вытянутые трупоположения на спине, с согнутыми в локтях руками, в плитовых могилах для многократного использования (Белый А., Белый О., Лобода, 1993).

Археология «полей военных сражсений». Данный раздел археологической науки традиционно сосредоточен на изучении топографии и материальных свидетельств военных сражений прошлого, независимо от их хронологии. К числу последних, применительно к позднесредневековой истории, относятся остатки лагерей, объектов военно-полевой фортификации, артиллерийских позиций, «братские могилы» погибших и скопления в культурном слое характерных для штурмов и осадных действий вещественных находок (стрел, пуль, ядер, деталей пушек, защитных доспехов и пр.). Обязательным в ходе исследований является сопоставление полученных археологических данных с имеющимся фондом нарративных и картографических источников о военных событиях (о некоторых теоритических аспектах этого направления археологии: Homann, 2013).

Современная «османская археология» Крыма включает лишь два примера подобных археологических объектов. Об одном из них - «поле сражения» во время осады и штурма османской армией Мангупской крепости летом - осенью 1475 г., мы уже говорили (рис. 2: 41). Другим примером позднесредневековых «полей военных сражений» в Крыму является поле Шумской битвы у с. Верхняя Кутузовка близ Алушты, состоявшейся 23 июля 1774 г. и завершившейся разгромом турецкого десанта русской армией под командованием генерал-поручика графа В.П. Мусина-Пушкина (рис. 2: 42). Об этих событиях хорошо известно по данным письменных и картографических источников. Локализовать их на местности удалось в ходе разведок 2009 г., дополненных небольшими шурфовочными работами и топографической съемкой сохранившихся полевых фортификационных объектов. Установлены, в частности, местона- 
хождения турецкой артиллерийской батареи и русского земляного укрепления, так называемого «Суворовского шанца» (Герасимов, Ткаченко, 2015).

Археологическое вещеведение. Тесно связано со всеми перечисленными направлениями «османской археологии» в Крыму, так как сосредоточено на целенаправленном изучении различных категорий массового археологического материала из раскопок крепостей, городов, поселений, некрополей и «полей военных сражений» на территории полуострова - керамики, изделий из глины, камня, кости, металла и пр. Конечной целью таких исследований является рассмотрение вещественных находок в культурном слое и археологических комплексов с ними как источников новой объективной информации о быте, занятиях, моде, художественных вкусах и социально-культурных предпочтениях населения региона. В таком контексте археологическому вещеведению близки термины «археология быта» или, в самом широком смысле, «археология повседневностей».

К сожалению, различные категории массового археологического материала имеют разную степень изученности. Лучше всего исследована керамика. На примере анализа письменных источников об истории КаффыКефе, реконструирована модель организации керамического производства в османских крепостях Крыма (Галенко, 2005). Благодаря И.Б. Тесленко и Д.Ю. Алядиновой качественно изданы позднесредневековые археологические материалы из раскопок крепостей и поселений Южного и Юго-Восточного Крыма (Судака, Партенита, Алушты, Малого Маяка), что позволило систематизировать данные об основных группах местных и импортных керамических изделий, маркирующих культурные горизонты османского времени (Тесленко, 2005; Тесленко, 2012; Тесленко, 2015; Teslenko, 2007; 2012; Алядинова, 2012; 2015; Алядинова, Тесленко, 2015; Алядинова, Тесленко, Майко, 2015; Тесленко, Майко, 2020).

В недавней статье И.Б. Тесленко и Д.Ю. Алядинова попытались подвести некоторые промежуточные итоги изучения структуры керамического комплекса османского Крыма для раннего этапа господства Османской империи на полуострове (конца XV - начала XVII вв.). Авторы выделяют не менее 12 крупных групп местных (неполивные изделия групп «Крым», «Юго-Восточ- ный Крым (ЮВК)», «подражания керамики с рельсовидным венчиком (ГРВ)» и поливная посуда групп «Крым» и «Мангуп») и импортных (неглазурованные сосуды группы ГРВ и глазурованные изделия групп «Miletus Ware», «Iznik Ware», «Maiolica Rinascimentali», «толстостенных чаш с бихромной росписью (ТЧБР)», «селадон» и «псевдо-селадон») изделий этого времени (рис. 12-17). На основе их анализа, делается ряд серьезных выводов о том, что после 1475 г. местный рынок испытывал серьезный кризис в повседневной керамической посуде, дефицит которой вплоть до XVII в. восполнялся импортом дешевой османской поливной и неполивной керамики. Местное керамическое производство возрождается, прежде всего, в Кефе в начале XVI в., но уже с использованием технологий и традиций османского гончарства. Преобладающие позиции в Крыму оно приобретет позднее, не ранее начала следующего столетия (Тесленко, Алядинова, 2019, с. 314-315).

С большинством из высказанных в этой работе заключений следует согласиться и еще раз отметить высокую степень их обоснованности. Некоторых замечаний требуют лишь отдельные из них. Прежде всего, совершенно не обязательным выглядит замена общепринятой атрибуции раннеосманской поливной керамики конца XV-XVI вв. группы «Polichrome Sgraffito Ware» или реже «Coloured Sgraffito Ware» несколько новодельным термином «толстостенные чаши с бихромной росписью (ТЧБР)» (Тесленко, Алядинова, 2019, с. 309, pис. 7: сp.: Papanikola-Bakirtzi, 1999, p. 97-114, 250-253, 256-257; Vroom, 2005, p. 144-145). Также преждевременным представляется выделение местной глазурованной посуды группы «Мангуп». Авторами не приведены находки из раскопок Мангупского городища в первой половине - середине XX в., которые они видели в фондах Бахчисарайского музея-заповедника, и которые послужили основанием для такой атрибуции. На наш взгляд, подобные поливные сосуды из Алушты и Малого Маяка, скорее, сопоставимы с уже упоминавшейся раннеосманской поливной керамикой группы «Polichrome Sgraffito Ware», чем с местной посудой этого времени (Тесленко, Алядинова, 2019, с. 308-309, рис. 8, 1-7). Нельзя также согласиться с тезисом об использовании способа декорирования бытовых неглазурованных сосудов линиями светлого ангоба исключительно для конца XV - начала XVII вв. (Тесленко, Алядинова, 
2019, с. 315). Такой элемент орнаментации керамических изделий характерен для всего османского периода в истории Крыма.

Подведем наиболее важные итоги нашего анализа. Несмотря на относительную молодость, «османская археология» в Крыму уже может рассматриваться как сложившееся направление археологических исследований на полуострове со своим предметом научных штудий и хорошо выраженной специализацией. Особо значительный прогресс достигнут при изучения ее базовых памятников - османских крепостей Крыма и столицы Крымского ханства, города Бахчисарая, а также в области археологического вещеведения, прежде всего, при анализе структуры керамических комплексов этого времени. Остальные направления исследований - археология поселений, некрополей, культовых и общественных сооружений и пр., испытывают недостаток в раскопанных полностью или хотя бы на широкой площади серии эталонных объектов.

Общими проблемами для изучения всех перечисленных категорий археологических памятников являются медленное введение в научный оборот результатов их раскопок во второй половине XX - начале XXI вв. и редкость специальных исследований различных сторон жизни населения Крыма в османский период его истории - домостроительства, занятий, быта, погребальной обрядности, художественной культуры и многих других. Безусловно, эти трудности представляются временными, но их решение может значительно быть ускорено посредством проведения специализированных научных форумов, профильных научных изданий и научно-образовательных программ.

\section{ЛИТЕРАТУРА}

Адаксина С.Б., Мыц В.Л., Ушаков С.В. Некоторые итоги архитектурно-археологических исследований крепости Чембало в 2002-2011 гг. // Адаксина С.Б., Мыц В.Л., Ушаков С.В. Отчет об археологических исследованиях средневековой крепости Чембало (г. Балаклава) в 2011 г. СПб.; Симферополь: Издательство Государственного Эрмитажа, 2012. С. 58-98.

Адаксина С.Б., Мыц В.Л. Отчет об археологических исследованиях средневековой крепости Чембало (г. Балаклава) в 2015 г. СПб.; Симферополь: Издательство Государственного Эрмитажа, 2016. 166 с.

Адаксина С.Б., Мыц В.Л. Генуэзская крепость Чембало: этапы формирования оборонительной системы и инфраструктуры города в XIV-XV вв. // Труды Государственного Эрмитажа. T. LXXXIX. Византия в контексте мировой культуры: материалы конференции, посвященной памяти А.В. Банк. СПб.: Издательство Государственного Эрмитажа, 2017. С. 103-139.

Адаксина С.Б., Алексеенко Н.А., Гинькут Н.В., Мыц В.Л. Отчет об археологических исследованиях средневековой крепости Чембало (г. Балаклава) в 2017 г. СПб.; Симферополь: Издательство Государственного Эрмитажа, 2018. 217 с.

Айбабина Е.А., Бочаров С.Г. Керамические подсвечники и светильники XV-XVIII вв. из Каффы // Херсонесский сборник. 1998. Вып. IX. С. 195-208.

Акчокракль О.Н. Новое из истории Чуфут-Кале // Известия Таврического общества истории, археологии и этнографии. 1928. Т. 2 (59). С. 158-172.

Акчокракль О.Н. Эпиграфические находки // Известия Таврического общества истории, археологии и этнографии. 1929. Т. 3 (60). С. 183-187.

Алексеенко Н.А., Дьячков С.В., Неделькин Е.В., Ступко М.В. Османский гарнизон Балыклагу в начале XVI в. (по письменным источникам и археологическим данным) // Сборник материалов XVII Международной научной конференции «Лазаревские чтения». Причерноморье: история, политика, география, культура / Под ред. О.А. Шпырко, В.В. Хапаева, А.В. Мартынкина, С.В. Ушакова, С.И. Рубцовой. Севастополь: Филиал МГУ в г. Севастополе, 2019. С. 38-40.

Алядинова Д.Ю. Неглазурованная керамика позднесредневекового Судака: по материалам раскопок 2008-2010 гг. // Археологический альманах, №28. Древняя и средневековая Таврика: сборник статей, посвященный 1800-летию города Судака / отв. ред. В.В. Майко. Донецк: Донбасс, 2012. С. 247-257.

Алядинова Д.Ю. Керамика османского времени из раскопок Партенита // Археологический альманах, №33. Древняя и средневековая Таврика. Сборник статей, посвященный юбилею Е.А. Паршиной / ред.--сост. И.Б. Тесленко. Киев: Видавець Олег Філюк, 2015. С. 451-481.

Алядинова Д.Ю., Тесленко И.Б. Некоторые древности османского периода из селения Алушта // Terra Alustiana MMXI: сборник научных трудов / ред.-сост. В.Г. Рудницкая, И.Б. Тесленко. Симферополь: Антиква, 2015. С. 157-199.

Алядинова Д.Ю., Тесленко И.Б., Майко В.В. Керамика из раскопок зольника османского периода в портовой части Сугдеи (по материалам исследований 2010 г.) // Археологический альманах, №33. Древ- 
няя и средневековая Таврика. Сборник статей, посвященный юбилею Е.А. Паршиной / ред.--сост. И.Б. Тесленко. Киев: Видавець Олег Філюк, 2015. С. 482-511.

Баранов И.А. Главные ворота средневековой Солдайи // Архитектурно-археологические исследования в Крыму. Киев: Наукова думка, 1988. С. 81-97.

Баранов В.И., Карлов С.В. Археологическое изучения поселения Мариамполис (предварительные итоги) // II Бахчисарайские научные чтения памяти Е.В. Веймарна: тезисы докладов и сообщений Международной научной конференции. Симферополь: Антиква, 2013. С. 8.

Белик Ю.Л. Османские оборонительные сооружения на Керченском полуострове (XVII-XVIII вв.). Казань: ZurKazan, 2016. 236 c.

Бельй А.В., Белый О.Б., Лобода И.И. Позднесредневековые плитовые могильники Юго-Западного Крыма // История и археология Юго-Западного Крыма: сборник научных трудов Бахчисарайского государственного историко-культурного заповедника / сост. Ю.М. Могаричев. Симферополь: Таврия, 1993. С. $160-174$.

Бобровский Т.А., Чуева Е.Е. Спелео-археологические исследования 2006 года на территории Бахчисарайского Свято-Успенского монастыря // Сугдейский сборник. Киев; Судак: Академпериодика, 2008. Вып. III. C. 281-295.

Боданинский У.А. Бахчисарайские памятники // Записки Крымского общества естествоиспытателей и любителей природы. 1917. Т. 6. С. 125-129.

Боданинский У.А. Татарские «дурбе»-мавзолеи в Крыму. Из истории искусства крымских татар // Известия Таврического общества истории, археологии и этнографии. 1927. Т. 1 (58). С. 195-201.

Боданинский У.А., Засыпкин Б.Н. Чуфут-Кале (по материалам раскопок 1928-1929 гг.) // Известия Таврического общества истории, археологии и этнографии. 1929. Т. 3 (60). С. 170-183.

Боданинский У.А. Археологическое и этнографическое изучение татар в Крыму. Симферополь: 1-я Гостиполитография «Крымполиграфтреста», 1930. $31 \mathrm{c.}$

Бочаров С.Г. Историческая топография Каффы (конец XIII в. - 1774 г.). Фортификация, культовые памятники, система водоснабжения. Автореферат диссертации на соискание ученой степени кандидата исторических наук. М., 2000. 21 с.

Бочаров С.Г. Топография города Керчи XVI-XVIII вв. // Археологические записки / ред. В.Я. Кияшко. Ростов-на-Дону: ДАО, 2005. Вып. 4. С. 145-150.

Бочаров С.Г. Картографические источники по топографии турецкого города Мангуп // Бахчисарайский историко-археологический сборник / ред. - сост. Ю.М. Могаричев. Симферополь: АнтиквА, 2008. Вып. 3. С. 191-211.

Бочаров С.Г. Ак-Мечеть: историческая топография города Крымского ханства // Средневековые тюрко-татарские государства. 2015. №7. С. 5-10.

Бочаров С.Г. Мечети города Каффа (Кефе) в 1340-1779 годах // Поволжская археология. 2016а. №2 (16). C. $120-137$.

Бочаров С.Г. Позднесредневековый могильник у античного городища «Чайка» в Северо-Западном Крыму // Очерки археологии Северо-Западного Крыма (по материалам городища «Чайка» и некрополя у поселка Заозерное): сборник научных статей. М., 2016б. С. 42-121.

Бочаров С.Г. Балаклава: введение в историческую топографию османского города 1475-1774 годов на Крымском полуострове // Stratum plus. 2019. №6. С. 321-328.

Бочаров С.Г., Кирилко В.П. Исторические и архитектурные метаморфозы Шейх-Коя // Stratum plus. 2016. №6. C. 371-392.

Бочаров С.Г., Сейтумеров Ш.С. Бахчисарай - введение в историческую топографию столицы Крымского ханства // Средневековые тюрко-татарские государства. 2017. №9. С. 21-30.

Бочаров С.Г., Ситдиков А.Г., Бездудный В.Г. Поиски загороднего дворца крымских ханов АшламаСарай. Археологические и геофизические исследования // Междисциплинарные исследования в археологии, этнографии и истории Сибири: материалы Международной научной конференции, посвященной 125-летию ученого и общественного деятеля Н.К. Ауэрбаха / отв. ред. А.С. Вдовин, Н.П. Макаров. Красноярск: Издательство СФУ, 2017. С. 127-134.

Веймарн E.B. Середньовічний комплекс фортеці Каламіта // Археологічні пам'ятки УРСР. Київ: видавництво АН УРСР, 1963. Т. ХІІІ: Стародавні пам'ятки Інкерманської долини. С. 74-89.

Волков И.В. Керамика Азова XIV-XVIII вв. (классификация и датировка). Автореф. Дисс... канд. истор. наук. М., 1992. 24 с. 
Гаврилюк Н.А., Ибрагимова А.М. Тюрбе хана Хаджи Герая (по материалам археологических исследований 2003-2008 гг.). Киев; Запорожье: Дикое Поле, 2010. 176 с.

Галенко О.І. Нікіта/Сікіта османського часу // Историческое наследие Крыма. 2004. №8. С. 79-91.

Галенко А.И. Гончарное производство и торговля в османской провинции Кефе // Поливная керамика Средиземноморья и Причерноморья X-XVIII вв.: Сборник научных трудов. Том I / ред. С.Г. Бочаров, В.Л. Мыц. Киев: Стилос, 2005. С. 493-504.

Герасимов B.E., Ткаченко В.B. Разведки в районе поля Шумского сражения 1774 года на территории Изобильненского сельсовета Алуштинского горсовета // Terra Alustiana MMXI: сборник научных трудов / ред.-сост. В.Г. Рудницкая, И.Б. Тесленко. Симферополь: Антиква, 2015. С. 200-233.

Герцен А.Г. Крепостной ансамбль Мангупа // Материалы по археологии, истории и этнографии Таврии. 1990. Вып. І. С. 87-166.

Гериен А.Г. По поводу новой публикации турецкого источника о завоевании Крыма // Материалы по археологии, истории и этнографии Таврии. 2001. Вып. VIII. С. 366-387.

Гериен А.Г. У истоков иудейской общины Мангупа // IV Боспорские чтения «Боспор Киммерийский и варварский мир в период античности и средневековья»: материалы Международной научной конференции. Керчь, 2003. С. 69-79.

Гериен А.Г., Землякова А.Ю., Науменко В.Е., Смокотина А.В. Стратиграфические исследования на юго-восточном склоне мыса Тешкли-бурун (Мангуп) // Материалы по археологии, истории и этнографии Таврии. 2006. Вып. ХІІ. С. 371-494.

Гериен А.Г., Иванова О.С., Науменко В.Е., Смокотина А.В. Археологические исследования в районе церкви св. Константина (Мангуп): I горизонт застройки (XVI-XVIII вв.) // Материалы по археологии, истории и этнографии Таврии. 2007. Вып. XIII. С. 233-298.

Гериен А.Г., Колтухов С.Г. Археологические работы в Арабатской крепости // Северное и Западное Причерноморье в античную эпоху и средневековье / под ред. С.Г. Бочарова, В. Кожокару. Симферополь: Таврия, 2009. С. 144-172.

Гериен А.Г., Могаричев Ю.М. Крепость драгоценностей. Кырк-Ор. Чуфут-Кале. Симферополь: Таврия, 1993. $128 \mathrm{c.}$

Гериен А.Г., Могаричев Ю.М. Восточная оборонительная стена Чуфут-Кале // Бахчисарайский историко-археологический сборник / ред. - сост. Ю.М. Могаричев, И.Н. Храпунов. Симферополь: Таврия-Плюс, 2001. Вып. 2. С. 279-319.

Гериен А.Г., Могаричев Ю.М. Кырк-Ер - Чуфут-Кале. Крепость на краю седьмого климата: исследование, путеводитель, альбом. Симферополь: Антиква, 2016. 312 с.

Герцен А.Г., Науменко В.Е. Поливная керамика из раскопок цитадели Мангупа // Поливная керамика Средиземноморья и Причерноморья X-XVIII вв.: сборник научных трудов. Т. I / под ред. С.Г. Бочарова, В.Л. Мыца. Киев: Стилос, 2005. С. 257-287.

Гериен А.Г., Науменко В.Е. Октагональная церковь цитадели Мангупа (Крым): вопросы хронологии // Труды Государственного Эрмитажа. T. LIII. Архитектура Византии и Древней Руси IX-XIII вв.: материалы международного семинара. СПб., 2010. С. 227-253.

Гериен А.Г., Науменко В.Е. Стратиграфия Мангупского городища: антропогенный и природногеографический контекст // XVI Боспорские чтения «Боспор Киммерийский и варварский мир в период античности и средневековья. Географическая среда и социум»: материалы Международной научной конференции. Керчь, 2015а. С. 88-100.

Гериен А.Г., Науменко В.Е. К изучению исторической топографии Мангупа: церковь Святого Константина // II Свято-Владимирские чтения: тезисы докладов и сообщений научной конференции, посвященной 1000-летию Святого равноапостольного князя Владимира. Севастополь: Н3 «Херсонес Таврический», 2015б. С. 16-18.

Герцен А.Г., Науменко В.Е. К дискуссии о ранней этнической истории крымских караимов: археологический аспект // Этнография Крыма XIX-XXI вв. и современные этнокультурные процессы: тезисы IV Международной научно-практической конференции / отв. ред. Ю.Н. Лаптев, Л.А. Науменко. Симферополь: Антиква, 2017б. С. 21-23.

Гериен А.Г., Науменко В.Е. Церковь Святого Георгия Мангупского городища. Общие итоги археологических исследований 2015-2016 гг. // Археология античного и средневекового города: сборник статей в честь С.Г. Рыжова / отв. ред. В.В. Майко. Севастополь; Калининград: РОСТ-ДОАФК, 2018. С. 12-44. 
Гериен А.Г., Науменко В.Е. Сакральная топография Мангупа: история изучения, каталог и перио-

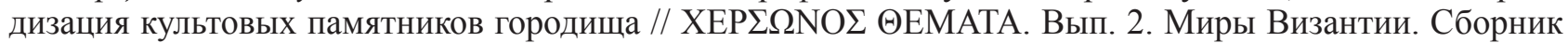
научных трудов / отв. ред. Н.А. Алексеенко. Симферополь: ООО «Колорит», 2019. С. 115-176.

Гериен А.Г., Науменко В.Е., Душенко А.А. Княжеский дворец Мангупского городища. Стратиграфия участка исследований 2006-2017 гг. (предварительное сообщение) // X Международный Византийский

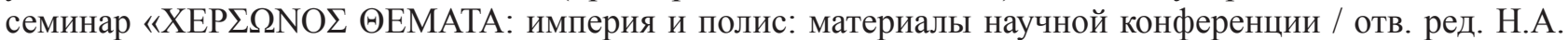
Алексеенко. Севастополь; Симферополь: ООО «Колорит», 2018. С. 53-58.

Гериен А.Г., Науменко В.Е., Шведчикова Т.Ю. Население Дороса-Феодоро по результатам комплексного археолого-антропологического анализа некрополей Мангупского городища (IV-XVII вв.). М.; СПб.: Нестор-История, 2017а. 272 с.

Гериен А.Г., Руев В.Л. Свинцовые пули из раскопок Мангупа // Материалы по археологии, истории и этнографии Таврии. 2008. Вып. XIV. С. 385-416.

Гусач И.Р., Моисеев Д.А. Типология производства крымской черепицы - «татарки» в позднесредневековое и Новое время: предварительные выводы // V Бахчисарайские научные чтения памяти Е.В. Веймарна: тезисы докладов и сообщений / ред.-сост. О.М. Стойкова. Бахчисарай: ГБУ РК БИКАМЗ, 2017. С. $16-18$.

Джанов А.В. «Храм с аркадой» в Судаке // Сугдейский сборник. Киев; Судак: Академпериодика, 2005. Вып. II. С. 654-669.

Душенко A.A. Нумизматический комплекс Мангупского княжеского дворца (раскопки 2006-2018

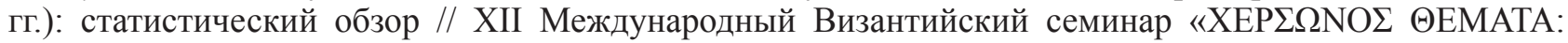
империя и полис: материалы научной конференции / отв. ред. Н.А. Алексеенко. Симферополь: Колорит, 2020. С. 91-98.

Дьячков C.B. Консульский замок генуэзской крепости Чембало XIV-XV вв. (по материалам археологических раскопок 1999-2008 гг.) // Генуэзская Газария и Золотая Орда / ред. С.Г. Бочаров, А.Г. Ситдиков. Казань; Кишинев: Институт археологии АН РТ, 2019. Т. 2. С. 771-789.

Засыпкин Б.Н. Памятники архитектуры крымских татар // Крым. Журнал общественно-научный и экскурсионный. 1927. №2 (4). С. 113-168.

Зиливинская Э.Д. Архитектура Золотой Орды. Часть І. Культовое зодчество. Казань: Отечество, 2014. $228 \mathrm{c}$.

Зиливинская Э.Д. Мечети Крымского ханства: опыт первичной классификации // Актуальные вопросы охраны и использования культурного наследия Крыма: материалы VII Всероссийской научно-практической конференции / ред.--сост. В. Е. Науменко, Т. А. Гогунская, Н. В. Кармазина. Симферополь: Ариал, 2020. С. 66-71.

Ибрагимова А.М. Бахчисарайский Ханский дворец XVI-XVIII вв. Киев: Видавець Олег Філюк, 2015. $360 \mathrm{c}$.

Исторический атлас Республики Крым. «Крепость драгоценностей. Кырк-Ор. Чуфут-Кале» / авт.сост. А.А. Волошинов, Ш.А. Эмруллаев, А.Ю. Полканова, И.Р. Каримов, научн. ред. С.Г. Бочаров. Казань: Фолиант, 2015. 276 с.

Кашовская Н.В. К итогам изучения караимского некрополя в ущелье Табана-дере (Мангуп): проблемы хронологии и периодизации // Материалы по археологии, истории и этнографии Таврии. 2017. Вып. XXII. C. 239-277.

Кирилко В.П. Археологическое исследование мусульманских мавзолеев-дюрбе Бахчисарая // Stratum plus. 2009. №6. C. 439-466.

Кирилко В.П. Мечеть в Эски-Сарае (Пионерское) // Stratum plus. 2012. №6. С. 261-297.

Кирилко В.П. Михраб мечети в Шейх-Кой // Поволжская археология. 2016. №2 (16). С. 138-150.

Коваль В.Ю., Волошинов А.А. Псевдо-селадон из Бахчисарая // Поливная керамика Средиземноморья и Причерноморья X-XVIII вв.: сборник научныХ трудов. Т. I / под ред. С.Г. Бочарова, В.Л. Мыца. Киев: Стилос, 2005. С. 457-461.

Кондаков В.П. О Бахчисарайском дворце и его «реставрации» // Искусство и художественная промышленность. СПб, 1899. № 6. С. 435-452.

Кутайсов В.А., Кутайсова М.В. Евпатория: Древний мир. Средние века. Новое время. Киев: Стилос, 2007. $284 \mathrm{c}$.

Лавров В.В. Разведки мечети Шейх-Кой в 2018 г. // История и археология Крыма. 2019. Вып. ХІ. С. 161-174. 
Майко В.В. Кырк-Ерский клад городища Чуфут-Кале в Юго-Западном Крыму. Киев: Академпериодика, 2007. 190 с.

Майко B.B., Джанов А.В. Археологические памятники Судакского региона Республики Крым. Симферополь: Ариал, 2015. 448 с.

Майко В.В., Джсанов А.В. Судак в период османского господства и некоторые вопросы исторической топографии (мечеть (?) Хаджи-бея) // Сугдейский сборник. Киев: вид. Филюк, 2016. Вып. VI. С. 14-43.

Мастыкова А.В., Решетова И.К., Чаукин С.Н, Ганичев К.А. Исследования средневекового поселения и могильника Су-Баш 1 в Юго-Восточном Крыму // Крым - Таврида. Археологические исследования в Крыму в 2017-2018 гг. М.: Институт археологии РАН, 2019. Т. II. С. 96-115.

МИРАС-НАСЛЕДИЕ. Татарстан - Крым. Город Болгар и изучение татарской культуры в Татарстане и в Крыму в 1923-1929 годах: в 3-х томах / сост. и отв. ред. С.Г. Бочаров, А.Г. Ситдиков. Казань: ООО «Астер Плюс», 2016.

Mыц В.Л. Каффа и Феодоро в XV в. Контакты и конфликты. Симферополь: Универсум, 2009. 528 с.

Mыı В.Л. Сарымамбаш-Кермен - укрепленная резиденция XIV-XVIII вв. беков Яшлавских - Сулешевых // Поволжская археология. 2018. №2 (24). С. 190-203.

Науменко В.Е., Сейдалиев Э.И., Сейдалиева Д.Э. Новые материалы к изучению исторической топографии средневекового Бахчисарая: по результатам археологических исследований 2012-2013 гг. // Материалы Конгресса исламской археологии России и стран СНГ / отв. ред. Х.М. Абдуллин, А.Г. Ситдиков. Казань: Институт археологии АН РТ, 2016. С. 228-239.

Науменко В.Е., Пономарев Л.Ю. Историческая топография Керчи конца XV-XVIII вв.: состояние источниковой базы и перспективы исследований // XIX Боспорские чтения «Боспор Киммерийский и варварский мир в период античности и средневековья. Традиции и инновации»: материалы Международной научной конференции. Симферополь; Керчь, 2018. С. 348-358.

Науменко В.Е., Гериен А.Г., Ганцеев В.К. Бахчисарайский Ханский дворе как объект культурного (археологического) наследия (по материалам раскопок 2018-2019 гг.) // Актуальные вопросы охраны и использования культурного наследия Крыма: материалы VII Всероссийской научно-практической конференции / ред.-сост. В. Е. Науменко, Т. А. Гогунская, Н. В. Кармазина. Симферополь: Ариал, 2020. C. $104-117$

Руев В.Л. Турецкое вторжение в Крым в 1475 г. Симферополь: Антиква, 2014. 308 с.

Ситдиков А.Г., Измайлов И.Л. Мусульманская археология: объем и содержание понятия // Поволжская археология. 2016. №2 (16). С. 8-17.

Теплякова А.Н. Фрагменты бархата из мавзолея в Ханлы-дере (Бахчисарай) // Восток (Oriens). 2016. №5. C. 137-152.

Тесленко И.Б. Турецкая керамика с росписью кобальтом в Крыму // Поливная керамика Средиземноморья и Причерноморья X-XVIII вв.: Сборник научных трудов. Том I / ред. С.Г. Бочаров, В.Л. Мыц. Киев: Стилос, 2005. С. 385-410.

Тесленко И.Б. Керамика из раскопок христианского храма с некрополем в с. Малый Маяк (бывш. Биюк-Ламбат, Южный берег Крыма) // Археологический альманах, №28. Древняя и средневековая Таврика: сборник статей, посвященный 1800-летию города Судака / отв. ред. В.В. Майко. Донецк: Донбасс, 2012. С. 225-246.

Тесленко И.Б. Одна из групп неполивной керамики Крыма XV в.: хронология и эволюция // История и археология Крыма. 2015. Вып. II. С. 428-436.

Тесленко И.Б., Алядинова Д.Ю. Влияние османского завоевания 1475 г. на культуру жителей Южного Крыма (по материалам керамических комплексов конца XV-XVI в.) // Stratum plus. 2019. №6. C. 295-320.

Тесленко И.Б., Лысенко А.В. Средневековый христианский храм на южной окраине с. Малый Маяк и его археологическое окружение // «О древностях Южного берега и гор Таврических»: сборник научных трудов по материалам конференции в честь 210-летия со дня рождения П.И. Кеппена / гл. ред. В.Л. Мыц. Киев: Стилос, 2004. С. 260-296.

Тесленко И.Б., Майко В.В. Керамический комплекс позднесредневековых усадеб в портовой части Судака (по материалам раскопа VI, 2006-2010 гг.) // История и археология Крыма. 2020. Вып. XII. C. 291-332.

Тур В.Г. Археологические исследования центрального квартала в Судакской крепости // Херсонесский колокол: сборник научных статей, посвященный 70-летию со дня рождения и 50-летию научной деятельности В.Н. Даниленко / под ред. Э.Б. Петровой. Симферополь: СОНАТ, 2008. С. 352-361. 
Филиппенко В.Ф. Новое в истории и археологии крепости Каламиты-Инкермана // Херсонесский сборник. 1996. Вып. VII. С. 143-152.

Якобсон А.Л. Средневековый Крым. Очерки истории и истории материальной культуры. М.; Л.: Наука, 1964. 232 с.

Baram U., Carroll L. The Future of the Ottoman Past // A Historical Archaeology of the Ottoman Empire. Breaking New Ground / eds. U. Baram, L. Carroll. New York; Boston; Dordrecht; London; Moscow: Kluwer Academic Publishers, 2002. P. 3-32.

Bintliff J. Medieval and Post-Medieval // Encyclopedia of Archaeology / editor- in-chief D.M. Pearsall. Amsterdam: Elsevier; Oxford: Academic Press, 2008. P. 1280-1298.

Çağlar F.T. The Historiography of Ottoman Archaeology: A Terra Incognita for Turkish Archaeologists // Cihannüma: Tarih ve Coğrafya Araştirmalari Dergisi. 2017. Sayi III/1. S. 109-122.

Hayes J.W. Excavations at Saraçhane in Istanbul. Vol. 2. The Pottery. Princeton, N.J.: Princeton University Press; Washington, D.C.: Dumbarton Oaks Research Library and Collection, 1992. 445 p.

Homann A. Battlefield Archaeology of Central Europe - With a Focus on Early Moderm Battlefields // Historical Archaeology in Central Europe / ed. N. Mehler. Rockville, 2013. P. 203-230.

Insoll T. The Archaeology of Islam. Oxford: Blackwell Publishers, 1998. 274 p.

Laszlovszky J., Rasson J. Post-Medieval or Historical Archaeology: Terminology and Discourses in the Archaeology of the Ottoman Period // Archaeology of the Ottoman Period in Hungary / eds. I. Gerelyes, G. Kovács. Budapest: Hungarian National Museum, 2003. P. 377-382.

Lees W.B., Burke H., Orser Ch.E. Historical Archaeology // Encyclopedia of Archaeology / ed. D.M. Pearsall. Amsterdam: Elsevier; Oxford: Academic Press, 2008. P. 1438-1447.

Northedge A. Archaeology and Islam // Companion Encyclopedia of Archaeology / ed. G. Barker. London; New York: Routledge, 1999. Vol. 2. P. 1077-1106.

Papanikola-Bakirtzi D. Byzantine Glazed Ceramics. The Art of Sgraffito. Athens: The Archaeological Receipts Fund, 1999. 270 p.

Teslenko I. Turkish Ceramics in the Crimea on the Eve of the Porta Invasion (Problems of Chronology of a Certain Group of Vessels) // Archaeometric and Archaeological Approaches to Ceramics: Papers presented at EMAC'05, 8th European Meeting on Ancient Ceramics, Lyon 2005 / ed. by S.Y. Waksman. Oxford, 2007. P. 187-193 (BAR International Series 1691).

Teslenko I. The Italian Majolica in the Crimea of the Turkish Supremacy Period (1475 - the Last Quarter of the 18th Century) // Atti del IX Congresso Internazionale sulla Ceramica Medievale nel Mediterraneo / a cura di S. Gelichi. Venezia, 2012. P. 212-214.

Vroom J. Byzantine to Moderm Pottery in the Aegean. An Introduction and Field Guide. Utrecht: Parnassus Press, 2005. 223 p.

\section{Информация об авторе:}

Науменко Валерий Евгеньевич, кандидат исторических наук, доцент кафедры истории древнего мира и средних веков ФГАОУ «Крымский федеральный университет им. В.И. Вернадского (г. Симферополь, Россия); byzance@rambler.ru, ORCID: 0000-0002-2590-6314, Researcher ID: W-7627-2018

\section{REFERENCES}

Adaksina, S. B., Myc, V. L., Ushakov, S. V. 2012. In Adaksina, S. B., Myc, V. L., Ushakov, S. V. Otchet $o b$ arheologicheskih issledovaniyah srednevekovoj kreposti Chembalo (g. Balaklava) v 2011 g. (Report on archaeological research of the medieval fortress of Chembalo (Balaklava) in 2011). Saint Petersburg.; Simferopol: "Izdatel'stvo Gosudarstvennogo Ermitazha" Publ. (in Russian).

Adaksina, S. B., Myc, V. L. 2016. Otchet ob arheologicheskih issledovaniyah srednevekovoj kreposti Chembalo (g. Balaklava) v 2015 g. (Report on archaeological research of the medieval fortress of Chembalo (Balaklava) in 2015). Saint Petersburg.; Simferopol: "Izdatel'stvo Gosudarstvennogo Ermitazha: Publ. (in Russian).

Adaksina, S. B., Myc, V. L. 2017. In Trudy Gosudarstvennogo Ermitazha. Vizantiya v kontekste mirovoj kul'tury: materialy konferencii, posvyashchennoj pamyati A.V. Bank (Transactions of the State Hermitage Museum. Byzantium within the Context of World Culture. Proceedings of the conference dedicated to the memory of A.V. Bank). LXXXIX. Saint Petersburg. 103-139. (in Russian).

Adaksina, S.B., Alekseenko, N. A., Gin'kut, N. V., Myc, V. L. 2018. Otchet ob arheologicheskih issledovaniyah srednevekovoj kreposti Chembalo (g. Balaklava) v 2017 g. (Report on archaeological research 
of the medieval fortress of Chembalo (Balaklava) in 2017). Saint Petersburg.; Simferopol: «Izdatel'stvo Gosudarstvennogo Ermitazha» Publ. (in Russian).

Ajbabina, E.A., Bocharov, S. G. 1998. In Khersonesskii sbornik (Chersonesos collection). IX. Sevastopol'. 195-208. (in Russian).

Akchokrakly, O.N. 1928. In Izvestiya Tavricheskogo obshchestva istorii, arheologii i etnografii (Proceedings of the Taurica society of history, archeology and ethnography). 2(59). Simferopol. 158-172. (in Russian).

Akchokrakly, O.N. 1929. In Izvestiya Tavricheskogo obshchestva istorii, arheologii $i$ etnografii (Proceedings of the Taurica society of history, archeology and ethnography). 3(60). Simferopol. 183-187. (in Russian).

Alekseenko, N.A., D'yachkov, S.V., Nedel'kin, E.V., Stupko, M.V. 2019. In Shpyrko O.A., Khapaev V.V., Martynkin A.V., Ushakov S.V., Rubtsova S.I. (eds.). Sbornik materialov XVII Mezhdunarodnoj nauchnoj konferencii «Lazarevskie chteniya». Prichernomor'e: istoriya, politika, geografiya, kul'tura (Collection of materials of the XVII International scientific conference "Lazarev readings". Black Sea Region: history, politics, geography, culture). Sevastopo': «Filial MGU v g. Sevastopole» Publ., 38-40 (in Russian).

Alyadinova, D. Yu. 2012. In Majko, V.V. (ed.). Arheologicheskij al'manah. Drevnyaya i srednevekovaya Tavrika: sbornik statej, posvyashchennyj 1800-letiyu goroda Sudaka (Archaeological Almanac. The Ancient and Medieval Taurica. The volume of collected papers dedicated to the 1800 years anniversary of Sudak city). 28. Donetsk: «Donbass» Publ., 247-257 (in Russian).

Alyadinova, D. Yu. 2015. In Teslenko, I. B. (ed.). Arheologicheskij al'manah. Drevnyaya i srednevekovaya Tavrika. Sbornik statej, posvyashchennyj yubileyu E.A. Parshinoj (Archaeological Almanac. The Ancient and Medieval Taurica. Collection of papers in honor E.A. Parshina). 33. Kiev: «Vidavec' Oleg Filyuk» Publ., 451-481 (in Russian).

Alyadinova, D. Yu., Teslenko, I. B. 2015. In Rudnitskaya, V. G., Teslenko, I. B. (eds.). Terra Alustiana MMXI: sbornik nauchnyh trudov (Terra Alustiana MMXI: collection of scientific papers). Simferopol: «Antikva» Publ., 157-199 (in Russian).

Alyadinova, D. Yu., Teslenko, I. B., Majko, V. V. 2015. In Teslenko, I. B. (ed.). Arheologicheskij al'manah. Drevnyaya i srednevekovaya Tavrika. Sbornik statej, posvyashchennyj yubileyu E.A. Parshinoj (Archaeological Almanac. The Ancient and Medieval Taurica. Collection of papers in honor E.A. Parshina). 33. Kiev: «Vidavec' Oleg Filyuk» Publ., 482-511 (in Russian).

Baranov, I. A. 1988. In Arhitekturno-arheologicheskie issledovaniya v Krymu (Architectural and archaeological research in Crimea). Kiev: «Naukova dumka» Publ., 81-97 (in Russian).

Baranov, V. I., Karlov, S. V. 2013. In II Bahchisarajskie nauchnye chteniya pamyati E.V. Vejmarna: tezisy dokladov i soobshchenij Mezhdunarodnoj nauchnoj konferencii (II Bakhchisaray Scientific Readings in Memory of E.V. Veimarn. Abstracts of Reports). Simferopol: «Antikva» Publ., 8 (in Russian).

Belik, Yu. L. 2016. Osmanskie oboronitel'nye sooruzheniya na Kerchenskom poluostrove (XVII-XVIII vv.) (Ottoman fortifications on the Kerch peninsula (XVII-XVIII centuries). Kazan: «ZurKazan» Publ. (in Russian).

Belyj, A. V., Belyj, O. B., Loboda, I .I. 1993. In Mogarichev Yu. M. (ed.). Istoriya i arheologiya YugoZapadnogo Kryma: sbornik nauchny trudov Bahchisarajskogo gosudarstvennogo istoriko-kul'turnogo zapovednika (History and Archeology of the South-Western Crimea: collection of scientific works of the Bakhchisaray State Historical and Cultural Reserve). Simferopol: «Tavriya» Publ., 160-174 (in Russian).

Bobrovskij, T. A., Chueva, E. E. 2008. In Sugdejskii sbornik (Sugdaia Collection). III. Kiev; Sudak: «Akademperiodika» Publ., 281-295 (in Russian).

Bodaninskij, U. A. 1917. In Zapiski Krymskogo obshchestva estestvoispytatelej i lyubitelej prirody (Notes of the Crimean Society of naturalists and nature lovers). 6. Simferopol, 125-129 (in Russian).

Bodaninskij, U.A. 1927. In Izvestiya Tavricheskogo obshchestva istorii, arheologii i etnografii (Proceedings of the Taurica society of history, archeology and ethnography). 1(58). Simferopol, 195-201 (in Russian).

Bodaninskij, U. A., Zasypkin, B. N. 1929. In Izvestiya Tavricheskogo obshchestva istorii, arheologii $i$ etnografii (Proceedings of the Taurica society of history, archeology and ethnography). 3(60). Simferopol, 170-183 (in Russian).

Bodaninskij, U.A. 1930. Arheologicheskoe i etnograficheskoe izuchenie tatar v Krymu. Simferopol: «1-ya Gostipolitografiya «Krympoligraftresta» Publ. (in Russian).

Bocharov, S. G., 2000. Istoricheskaya topografiya Kaffy (konec XIII v. - 1774 g.). Fortifikaciya, kul'tovye pamyatniki, sistema vodosnabzheniya (Historical topography of Kaffa (late XIII century-1774). Fortification, religious monuments, water supply system.). Thesis of Diss. Of Candidate historical Sciences. Moscow (in Russian). 
Bocharov, S. G., 2005. In Kiyashko V. Ya. (ed.). Arheologicheskie zapiski (Historical notes). 4. Rostov-naDonu: «DAO» Publ., 145-150 (in Russian).

Bocharov, S.G., 2008. In Mogarichev Yu.M. (ed.). Bahchisarajskij istoriko-arheologicheskij sbornik (Bakhchisaray Historical and Archaeological Collection). 3. Simferopol: «AntikvA» Publ., 191-211 (in Russian).

Bocharov, S.G., 2015. In Srednevekovye tyurko-tatarskie gosudarstva (Medieval Turkic-Tatar States). 7. Kazan, 5-10 (in Russian).

Bocharov, S.G. 2016a. In Povolzhskaya arheologiya (The Volga River Region Archaeology). 2(16). Kazan, 120-137 (in Russian).

Bocharov, S. G. 2016b. In Ocherki arheologii Severo-Zapadnogo Kryma (po materialam gorodishcha «Chajka» i nekropolya u poselka Zaozernoe): sbornik nauchnyh statej (Essays on the archeology of the North-Western Crimea (on the materials of the settlement "Chaika" and the necropolis near the village of Zaozernoye): collection of scientific articles). Moscow, 42-121 (in Russian).

Bocharov, S. G. 2019. In Stratum plus. 6. 321-328 (in Russian).

Bocharov, S. G., Kirilko, V. P. 2016. In Stratum plus. 6. 371-392 (in Russian).

Bocharov, S. G., Sejtumerov, Sh. S. 2017. In Srednevekovye tyurko-tatarskie gosudarstva (Medieval Turkic-Tatar States). 9. Kazan, 21-30 (in Russian).

Bocharov, S. G., Sitdikov, A.G., Bezdudnyj, V.G. 2017. In Vdovin A.S., Makarov N.P. (ed.). Mezhdisciplinarnye issledovaniya $v$ arheologii, etnografii $i$ istorii Sibiri: materialy Mezhdunarodnoj nauchnoj konferencii, posvyashchennoj 125-letiyu uchenogo i obshchestvennogo deyatelya N.K. Auerbaha (Interdisciplinary Research in Archaeology, Ethnography and History of Siberia: proceedings of the International scientific conference dedicated to the 125th anniversary of the scientist and public figure N.K. Auerbach). Krasnoyarsk: «Izdatel'stvo SFU» Publ., 127-134 (in Russian).

Vejmarn, E.V. 1963. In Arheologichni pam'yatki URSR (Archaeological monuments of Ukraine). XIII: Starodavni pam'yatki Inkermans'koï dolini (Ancient monuments of Inkerman valley). Kiev: «Vidavnictvo AN URSR» Publ., 74-89 (in Ukraine).

Volkov, I.V. 1992. Keramika Azova XIV-XVIII vv. (klassifikaciya i datirovka) (The Pottery of Azov XIV$X V I I I$ centuries (the classification and dating). Thesis of Diss. Of Candidate historical Sciences. Moscow (in Russian).

Gavrilyuk, N. A., Ibragimova, A. M. 2010. Tyurbe hana Hadzhi Geraya (po materialam arheologicheskih issledovanij 2003-2008 gg.) (Tjurbe of khan Hadzhi Geraja (on materials of archaeological researches of 2003-2008). Kiev; Zaporozh'e: «Dikoe Pole» Publ. (in Russian).

Galenko, O.I. 2004. In Istoricheskoe nasledie Kryma (The Historical Heritage of the Crimea). 8. Simferopol, 79-91 (in Ukraine).

Galenko, A.I. 2005. In Bocharov, S.G., Myts V.L. (eds.). Polivnaya keramika Sredizemnomor'ya $i$ Prichernomor'ya X-XVIII vv.: sbornik nauchnyh trudov (Glazed Pottery of Mediterranean and Black Sea region of the X-XVIII senturies). I. Kiev: «Stilos» Publ., 493-504 (in Russian).

Gerasimov, V.E., Tkachenko, V.V. 2015. In Rudnitskaya, V. G., Teslenko, I. B. (eds.). Terra Alustiana MMXI: sbornik nauchnyh trudov (Terra Alustiana MMXI: collection of scientific papers). Simferopol: «Antikva» Publ., 200-233 (in Russian).

Gertsen. A.G. 1990. In Materialy po arheologii, istorii i etnografii Tavrii (Materials in Archaeology, History and Ethnography of Tauria). I. Simferopol, 87-166 (in Russian).

Gertsen, A. G. 2001. In Materialy po arheologii, istorii i etnografii Tavrii (Materials in Archaeology, History and Ethnography of Tauria). VIII. Simferopol, 366-387 (in Russian).

Gertsen, A. G. 2003. In IV Bosporskie chteniya «Bospor Kimmerijskij i varvarskij mir v period antichnosti i srednevekov'ya»: materialy Mezhdunarodnoj nauchnoj konferencii (IV Bosporan Readings "Kimmerian Bosporus and the World of Barbarians in Antiquity and the Middle Ages»: the materials of International Scholarly Conference). Kerch', 69-79 (in Russian).

Gertsen. A.G., Zemlyakova, A.Yu., Naumenko, V.E., Smokotina, A.V. 2006. In Materialy po arheologii, istorii i etnografii Tavrii (Materials in Archaeology, History and Ethnography of Tauria). XII. Simferopol, 371-494 (in Russian).

Gertsen, A. G., Ivanova, O. S., Naumenko, V. E., Smokotina, A. V. 2007. In Materialy po arheologii, istorii i etnografii Tavrii (Materials in Archaeology, History and Ethnography of Tauria). XIII. Simferopol, 233-298 (in Russian). 
Gertsen, A. G., Koltuhov, S. G. 2009. In Bocharova S.G., Kozhokaru V. (eds.). Severnoe i Zapadnoe Prichernomor'e v antichnuyu epohu i srednevekov'e (North and West Black Sea Area during Antiquity and the Middle Ages). Simferopol: «Tavriya» Publ., 144-172 (in Russian).

Gertsen, A. G., Mogarichev, Yu. M. 1993. Krepost' dragocennostej. Kyrk-Or. Chufut-Kale (Fortress of Jewels. Kyrk-Or. Chufut-Kale). Simferopol: «Tavriya» Publ. (in Russian).

Gertsen, A. G., Mogarichev, Yu.M. 2001. In Mogarichev Yu.M., Khrapunov I.N. (eds.). Bahchisarajskij istoriko-arheologicheskij sbornik (Bakhchisaray Historical and Archaeological Collection). 2. Simferopol: «Tavriya-Plyus» Publ., 279-319 (in Russian).

Gertsen, A. G., Mogarichev, Yu.M. 2016. Kyrk-Er-Chufut-Kale. Krepost' na krayu sed'mogo klimata: issledovanie, putevoditel', al'bom (Kyrk-Yer-Chufut-Kale. The Fortress on the Edge of he 7th Klima). Simferopol: «Antikva» Publ. (in Russian).

Gertsen, A. G., Naumenko, V.E. 2005. In Bocharov, S.G., Myts V.L. (eds.). Polivnaya keramika Sredizemnomor'ya i Prichernomor'ya X-XVIII vv.: sbornik nauchnyh trudov (Glazed Pottery of Mediterranean and Black Sea region of the X-XVIII senturies). I. Kiev: «Stilos» Publ., 257-287 (in Russian).

Gertsen, A. G., Naumenko, V.E. 2010. In Trudy Gosudarstvennogo Ermitazha. Arhitektura Vizantii i Drevnej Rusi IX-XIII vv.: materialy mezhdunarodnogo seminara (Transactions of the State Hermitage Museum. Architecture of Byzantium and Kievan Rus from the 9th to the 12th Centuries: materials of the International seminar). LIII. Saint Petersburg., 227-253 (in Russian).

Gertsen, A. G., Naumenko, V.E. 2015a. In XVI Bosporskie chteniya «Bospor Kimmerijskij i varvarskij mir v period antichnosti i srednevekov'ya. Geograficheskaya sreda i socium»: materialy Mezhdunarodnoj nauchnoj konferencii (XVI Bosporan Readings "Kimmerian Bosporus and the World of Barbarians in Antiquity and the Middle Ages. Geographical Environment and Society»: the materials of International Scholarly Conference). Kerch, 88-100 (in Russian).

Gertsen, A. G., Naumenko, V.E. 2015b. In II Svyato-Vladimirskie Chteniya: tezisy dokladov i soobshchenij nauchnoj konferencii, posvyashchennoj 1000-letiyu Svyatogo ravnoapostol'nogo knyazya Vladimira (II Saint-Vladimir's Readings: abstracts of scientific conference, dedicated 1000-anniversary of Saint Prince Vladimir, equal to the apostles). Sevastopol: «NZ «Hersones Tavricheskij» Publ., 6-18 (in Russian).

Gertsen, A. G., Naumenko, V.E., Shvedchikova, T.Yu. 2017a. Naselenie Dorosa-Feodoro po rezul'tatam kompleksnogo arheologo-antropologicheskogo analiza nekropolej Mangupskogo gorodishcha (IV-XVII vv.) (The population of Doros-Feodoro according to the results of a comprehensive archaeological and anthropological analysis of the necropolises of the Mangup settlement (IV-XVII centuries). Moscow; Saint Petersburg.: «Nestor-Istoriya» Publ. (in Russian).

Gertsen, A. G., Naumenko, V.E. 2017b. In Laptev Yu.N., Naumenko L.A. Etnografiya Kryma XIX-XXI vv. i sovremennye etnokul'turnye processy: tezisy IV Mezhdunarodnoj nauchno-prakticheskoj konferencii (The Ethnography of the Crimea in XIX-XXI centuries and Modern Ethno-Cultural Processes: abstracts of the IV International Scientific and Practical Conference). Simferopol: «Antikva» Publ., 21-23 (in Russian).

Gertsen, A. G., Naumenko, V.E. 2018. In Majko V.V. (ed.). Arheologiya antichnogo i srednevekovogo goroda: sbornik statej v chest' S.G. Ryzhova (Archaeology of the Ancient and Medieval City. Essays presented in honor of S. G. Ryzhov). Sevastopol; Kaliningrad: «ROST-DOAFK» Publ., 12-44 (in Russian).

Gertsen, A. G., Naumenko, V.E., Dushenko, A.A. 2018. In Alekseenko N.A. (ed.). X Mezhdunarodnyj Vizantijskij seminar «XEP $\Sigma \Omega N O \Sigma \Theta E M A T A$ : imperiya i polis: materialy nauchnoj konferencii (XInternational Byzantine Seminar «XEP $\Sigma \Omega N O \Sigma \Theta E M A T A$ : Empire and Polis: materials of scholarly conference). Sevastopol; Simferopol: «Kolorit» Publ., 53-58 (in Russian).

Gertsen. A.G., Naumenko, V.E. 2019. In Alekseenko N.A. (ed.). XEP $\Sigma Q N O \Sigma$ @EMATA. Vyp. 2. Miry Vizantii. Sbornik nauchny trudov (XEP $\Sigma \Omega N O \Sigma$ QEMATA. Vol. 2. Worlds of Byzantium. Collection of scientific works). Simferopol: «Kolorit» Publ., 115-176 (in Russian).

Gertsen, A. G., Ruev, V.L. 2008. In Materialy po arheologii, istorii i etnografii Tavrii (Materials in Archaeology, History and Ethnography of Tauria). XIV. Simferopol, 385-416 (in Russian).

Gusach, I.R., Moiseev, D.A. 2017. In Stojkova O.M. (ed.). V Bahchisarajskie nauchnye chteniya pamyati E.V. Vejmarna: tezisy dokladov i soobshchenij (V Bakhchisaray Scholarly Readings in memory of E.V. Vejmarn: abstracts). Bakhchisaray: «GBU RK BIKAMZ» Publ., 16-18 (in Russian).

Dzhanov, A.V. 2005. In Sugdejskii sbornik (Sugdaia Collection). II. Kiev; Sudak: «Akademperiodika» Publ., 654-669 (in Russian).

Dushenko, A.A. 2020. In Alekseenko N.A. (ed.). XII Mezhdunarodnyj Vizantijskij seminar «XEP $\Sigma Q N O \Sigma$ $\Theta E M A T A$ : imperiya i polis: materialy nauchnoj konferencii (XII International Byzantine Seminar «XEP $\Sigma \Omega N O \Sigma$ 
@EMATA: Empire and Polis: materials of scholarly conference). Simferopol: «Kolorit» Publ., 91-98 (in Russian).

D'yachkov, S.V. 2019. In Bocharov, S. G., Sitdikov A. G. (eds.). Genuezskaia Gazariia i Zolotaya Orda (The Genoese Gazaria and the Golden Horde). 2. Kazan; Kishinev: Institute of Archaeology named after A. Kh. Khalikov, Tatarstan Academy of Sciences., 771-789 (in Russian).

Zasypkin, B.N. 1927. In Krym. Zhurnal obshchestvenno-nauchnyj i ekskursionnyj (Crimea. Journal of social science and sightseeing). 2(4). Moscow, 113-168 (in Russian).

Zilivinskaya, E.D. 2014. Arhitektura Zolotoj Ordy. I. Kul'tovoe zodchestvo (The Golden Horde Architecture. I. Cult Monuments). Kazan: "Otechestvo" Publ. (in Russian).

Zilivinskaya, E.D. 2020. In Naumenko V.E., Gogunskaya T.A., Karmazina N.V. (eds.). Aktual'nye voprosy ohrany $i$ ispol'zovaniya kul'turnogo naslediya Kryma: materialy VII Vserossijskoj nauchno-prakticheskoj konferencii (Actual Issues of Protection and Use of the Cultural Heritage of the Crimea: materials of the VII All-Russian scientific and practical conference). Simferopol: «Arial» Publ., 66-71 (in Russian).

Ibragimova, A.M. 2015. Bahchisarajskij Hanskij dvorec XVI-XVIII vv. (Bakhchisarai Khan's Palace). Kiev: "Vidavec' Oleg Filyuk" Publ. (in Russian).

Bocharov, S.G. (ed.), Voloshinov A.A., Emrullaev Sh.A., Polkanova A.Yu., Karimov I.R. (athors). Istoricheskij atlas Respubliki Krym. «Krepost' dragocennostej. Kyrk-Or. Chufut-Kale» (Historical Atlas of the Republic of Crimea. "The fortress of jewels. Kyrk-Or. Chufut-Kale»). Kazan: «Foliant» Publ. (in Russian).

Kashovskaya, N.V. 2017. In Materialy po arheologii, istorii i etnografii Tavrii (Materials in Archaeology, History and Ethnography of Tauria). XXII. Simferopol, 239-277 (in Russian).

Kirilko, V. P.2009. In Stratum plus. 6. 439-466 (in Russian).

Kirilko, V. P.2012. In Stratum plus. 6. 261-297 (in Russian).

Kirilko, V. P.2016. In Povolzhskaya arheologiya (The Volga River Region Archaeology). 2(16). Moscow, $138-150$ (in Russian).

Koval', V.Yu., Voloshinov, A.A. 2005. In Bocharov, S.G., Myts V.L. (eds.). Polivnaya keramika Sredizemnomor'ya i Prichernomor'ya X-XVIII vv.: sbornik nauchnyh trudov (Glazed Pottery of Mediterranean and Black Sea region of the X-XVIII senturies). I. Kiev: «Stilos» Publ., 457-461 (in Russian).

Kondakov, V.P. 1899. In Iskusstvo i hudozhestvennaya promyshlennost' (Art and the art industry). 6. Saint Petersburg, 435-452 (in Russian).

Kutajsov, V.A., Kutajsova, M.V. 2007. Evpatoriya: Drevnij mir. Srednie veka. Novoe vremya (Evpatoria: The Ancient World. The Middle Ages. The Modern History). Kiev: «Stilos» Publ. (in Russian).

Lavrov, V.V. 2019. In Istoriya i arheologiya Kryma (The History and the Archaeology of the Crimea). XI. Simferopol, 161-174 (in Russian).

Majko, V. V. 2007. Kyrk-Erskij klad gorodishcha Chufut-Kale v Yugo-Zapadnom Krymu (Kirk-Er Treasure of Chufut-Kale in the South-Western Crimea). Kiev: «Akademperiodika» Publ. (in Russian).

Majko, V. V., Dzhanov, A. V. 2015. Arheologicheskie pamyatniki Sudakskogo regiona Respubliki Krym (Archaeological monuments of the Sudak region of the Republic of Crimea.). Simferopol: «Arial» Publ. (in Russian).

Majko, V. V., Dzhanov, A. V. 2016. In Sugdejskij sbornik (Sugdaia Collection). VI. Kiev: «vid. Filyuk» Publ., 14-43 (in Russian).

Mastykova, A. V., Reshetova, I. K., Chaukin, S. N, Ganichev, K. A. 2019. In Krym - Tavrida. Arheologicheskie issledovaniya v Krymu v 2017-2018 gg. (Crimea-Tavrida. Archaeological studies in the Crimea in 2017-2018). II. Moscow: Institute of Archaeology, RAS, 96-115 (in Russian).

Bocharov, S. G., Sitdikov, A.G. (eds.). 2016. MIRAS-NASLEDIE. Tatarstan - Krym. Gorod Bolgar $i$ izuchenie tatarskoj kul'tury v Tatarstane i v Krymu v 1923-1929 godah: v 3-h tomah (MIRAS-NASLEDIE. Tatarstan and Crimea. The City of Bolgar and the study of Tatar culture in Tatarstan and the Crimea in 1923-1929: in 3 volumes). Kazan: «Aster Plyus» Publ. (in Russian).

Myts, V.L. 2009. Kaffa i Feodoro v XV v. Kontakty i konflikty (Kaffa and Theodoro in the XV century. Contacts and conflicts). Simferopol: «Universum» Publ. (in Russian).

Myts, V.L. 2018. In Povolzhskaya arheologiya (The Volga River Region Archaeology). 2(24), 190-203 (in Russian).

Naumenko, V.E., Sejdaliev, E.I., Sejdalieva, D.E. 2016. In Abdullin H.M., Sitdikov A.G. (eds.). Materialy Kongressa islamskoj arheologii Rossii i stran SNG (The Materials of the Congress of Islamic Archeology of 
Russia and CIS countries). Kazan: Institute of archaeology named after A. Kh. Khalikov, TAS, 228-239 (in Russian).

Naumenko, V.E., Ponomarev, L.Yu. 2018. In XIX Bosporskie chteniya «Bospor Kimmerijskij i varvarskij mir $v$ period antichnosti $i$ srednevekov'ya. Tradicii i innovacii»: materialy Mezhdunarodnoj nauchnoj konferencii ((XIX Bosporan Readings "Kimmerian Bosporus and the World of Barbarians in Antiquity and the Middle Ages. Traditions and Innovations»: the materials of International Scholarly Conference).). Simferopol; Kerch, 348-358 (in Russian).

Naumenko, V.E., Gercen, A.G., Gancev, V.K. 2020. In Naumenko V.E., Gogunskaya T.A., Karmazina N.V. (eds.). Aktual'nye voprosy ohrany i ispol'zovaniya kul'turnogo naslediya Kryma: materialy VII Vserossijskoj nauchno-prakticheskoj konferencii (Actual Issues of Protection and Use of the Cultural Heritage of the Crimea: materials of the VII All-Russian scientific and practical conference). Simferopol: "Arial" Publ., 104-117 (in Russian).

Ruev, V.L. 2014. Tureckoe vtorzhenie v Krym v 1475 g. (Turkish invasion of Crimea in 1475). Simferopol: "Antikva" Publ. (in Russian).

Sitdikov, A.G., Izmajlov, I.L. 2016. In Povolzhskaya arheologiya (The Volga River Region Archaeology). 2(16), 8-17 (in Russian).

Teplyakova, A.N. 2016. In Vostok (Oriens). 5. Moscow, 137-152 (in Russian).

Teslenko, I. B., Lysenko, A.V. 2004. In Myts V.L. (ed.). «O drevnostyah Yuzhnogo berega i gor Tavricheskih»: sbornik nauchny trudov po materialam konferencii v chest' 210-letiya so dnya rozhdeniya P.I. Keppena ("On the antiquities of the Southern Coast and the Tauric mountains": collection of scientific papers on the conference in Honor of the 210th anniversary of the birth of P.I. Keppen). Kiev: "Stilos" Publ., 260-296 (in Russian).

Teslenko, I. B. 2005. In Bocharov, S.G., Myts V.L. (eds.). Polivnaya keramika Sredizemnomor'ya $i$ Prichernomor'ya X-XVIII vv.: sbornik nauchnyh trudov (Glazed Pottery of Mediterranean and Black Sea region of the X-XVIII senturies). I. Kiev: "Stilos" Publ., 385-410 (in Russian).

Teslenko, I. B. 2012. In Majko, V.V. (ed.). Arheologicheskij al'manah. Drevnyaya i srednevekovaya Tavrika: sbornik statej, posvyashchennyj 1800-letiyu goroda Sudaka (Archaeological Almanac. The Ancient and Medieval Taurica. The volume of collected papers dedicated to the 1800 years anniversary of Sudak city). 28. Donetsk: «Donbass» Publ., 225-246 (in Russian).

Teslenko, I. B. 2015. In Istoriya $i$ arheologiya Kryma (The History and the Archaeology of the Crimea). II. Simferopol, 428-436 (in Russian).

Teslenko, I. B., Alyadinova, D. Yu. 2019. In Stratum plus. 6. 295-320 (in Russian).

Teslenko, I. B., Majko, V.V. 2020. In In Istoriya i arheologiya Kryma (The History and the Archaeology of the Crimea). XII. Simferopol, 291-332 (in Russian).

Tur, V.G. 2008. In Petrova E.B. (ed.). Khersonesskii kolokol: sborniknauchnyh statej, posvyashchennyj 70letiyu so dnya rozhdeniya i 50-letiyu nauchnoj deyatel'nosti V.N. Danilenko (Chersonesus Bell: a Collection of scientific articles dedicated to the 70th anniversary of the birth and 50th anniversary of the scientific activity of V.N. Danilenko). Simferopol: «SONAT» Publ., 352-361 (in Russian).

Filippenko, V.F. 1996. In Khersonesski sbornik (Chersonesos collection). VII. Sevastopol', 143-152 (in Russian).

Yakobson, A.L. 1964. Srednevekovyj Krym. Ocherki istorii i istorii material'noj kul'tury (The Medieval Crimea. Essays on the History and History of material culture.). Moscow; Leningrad: "Nauka" Publ. (in Russian).

Baram, U., Carroll, L. 2002. In Baram U., Carroll L. (eds.). A Historical Archaeology of the Ottoman Empire. Breaking New Ground. New York; Boston; Dordrecht; London; Moscow: Kluwer Academic Publishers, 3-32 (in English)

Bintliff, J. 2008. In Pearsall D.M. (ed.). Encyclopedia of Archaeology. Amsterdam: Elsevier; Oxford: Academic Press, 1280-1298 (in English)

Çağlar, F.T. 2017. In Cihannüma: Tarih ve Coğrafya Araştirmalari Dergisi. III/1. 109-122 (in English)

Hayes, J.W. 1992. In Excavations at Saraçhane in Istanbul. Vol. 2. The Pottery. Princeton, N.J.: Princeton University Press; Washington, D.C.: Dumbarton Oaks Research Library and Collection (in English)

Homann, A. 2013. In Mehler N. (ed.). Historical Archaeology in Central Europe. Rockville, 203-230 (in English)

Insoll, T. 1998. The Archaeology of Islam. Oxford: Blackwell Publishers (in English). 
Laszlovszky, J., Rasson, J. 2003. In Gerelyes I., Kovács G. (eds.). In Archaeology of the Ottoman Period in Hungary. Budapest: Hungarian National Museum, 377-382.

Lees, W.B., Burke, H., Orser, Ch.E. 2008. In Pearsall D.M. (ed.). Encyclopedia of Archaeology . Amsterdam: Elsevier; Oxford: Academic Press, 1438-1447 (in English).

Northedge, A. 1999. In Barker, G. (ed.). Companion Encyclopedia of Archaeology. 2. London; New York: Routledge, 1077-1106 (in English).

Papanikola-Bakirtzi, D. 1999. Byzantine Glazed Ceramics. The Art of Sgraffito. Athens: The Archaeological Receipts Fund (in English).

Teslenko, I. 2007. In Waksman S.Y. (ed.). Archaeometric and Archaeological Approaches to Ceramics: Papers presented at EMAC'05, 8th European Meeting on Ancient Ceramics, Lyon 2005. Oxford, 187-193 (BAR International Series 1691) (in English).

Teslenko, I. 2012. In Gelichi S. (ed.). Atti del IX Congresso Internazionale sulla Ceramica Medievale nel Mediterraneo. Venezia, 212-214 (in English).

Vroom, J. 2005. Byzantine to Moderm Pottery in the Aegean. An Introduction and Field Guide. Utrecht: Parnassus Press (in English).

\section{About the Author:}

Naumenko Valery E., Candidate of Historical Sciences, Associate Professor of Department of Ancient and Middle Ages History, V. I. Vernadsky Crimean Federal University, Academician Vernadsky Ave. 4, Simferopol, 295007, Russian Federation; byzance@rambler.ru, ORCID: 0000-0002-2590-6314, Researcher ID: W-7627-2018

Статья поступила в журнал 01.08.2020 г. Статья принята к публикации 01.09.2020 г. 
Puc. 3 .
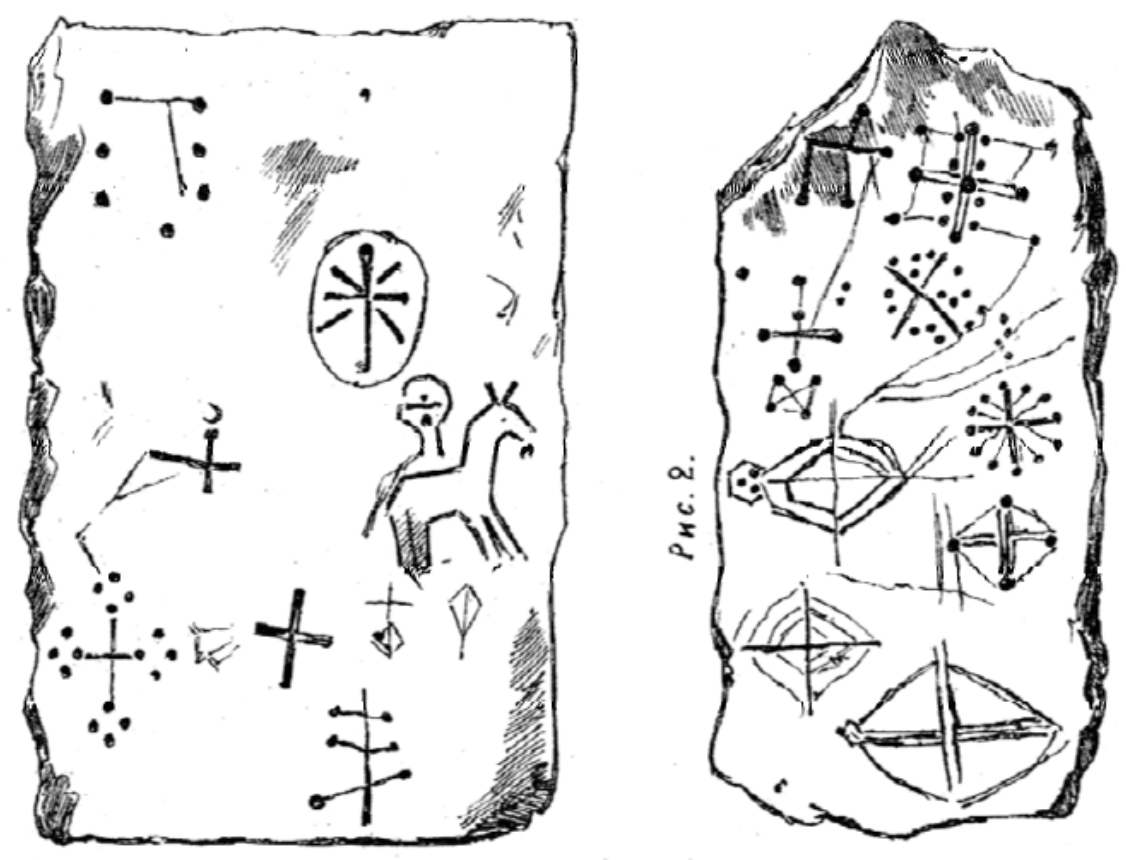

Puc. $\%$.

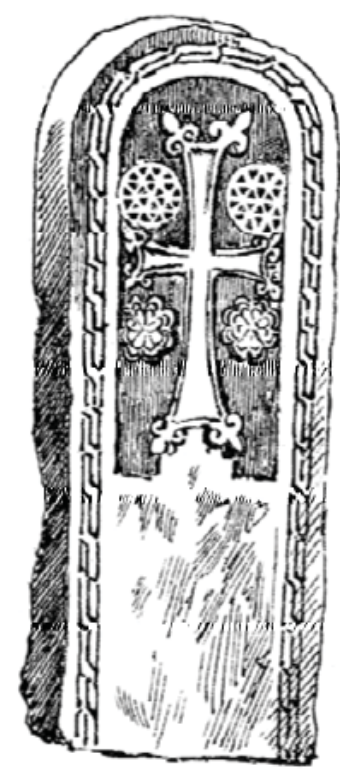

Pue, 4.

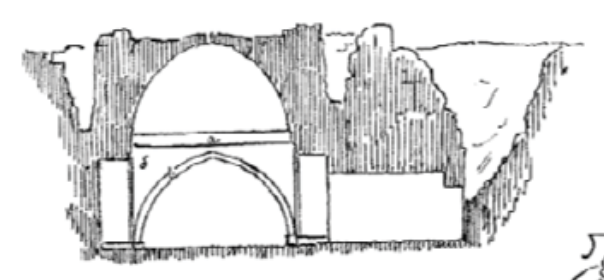

Pue. 9
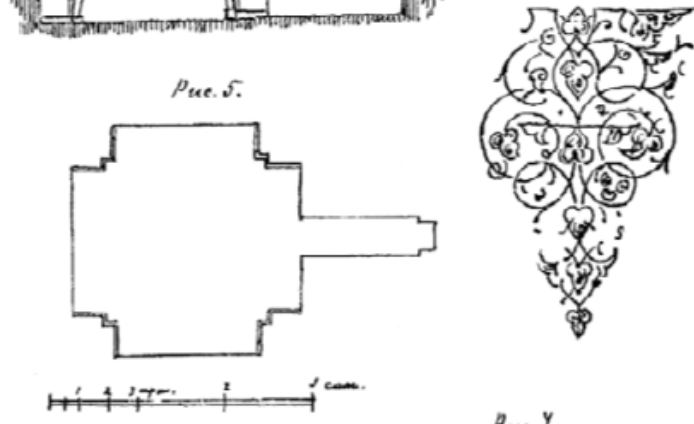

Pнс. 8.
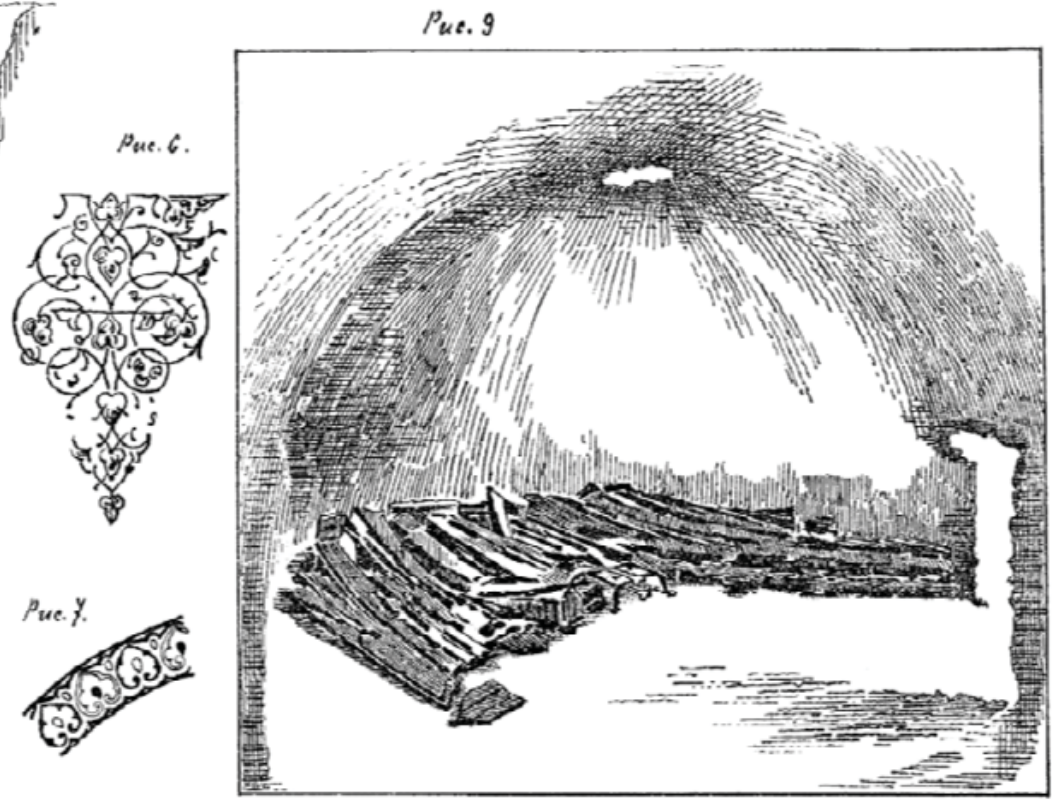

Рис. 1. Материалы археологического изучения дюрбе в ущелье Ханлы-дере (Бахчисарай) в 1898-1899 гг. (по: Кирилко, 2009, с. 441, рис. 2).

Fig. 1. The materials of the archaeological study of Durbe in the Khanly-dere (Bakhchisaray) in 1898-1899 (according to: Kirilko, 2009, p. 441, fig. 2). 


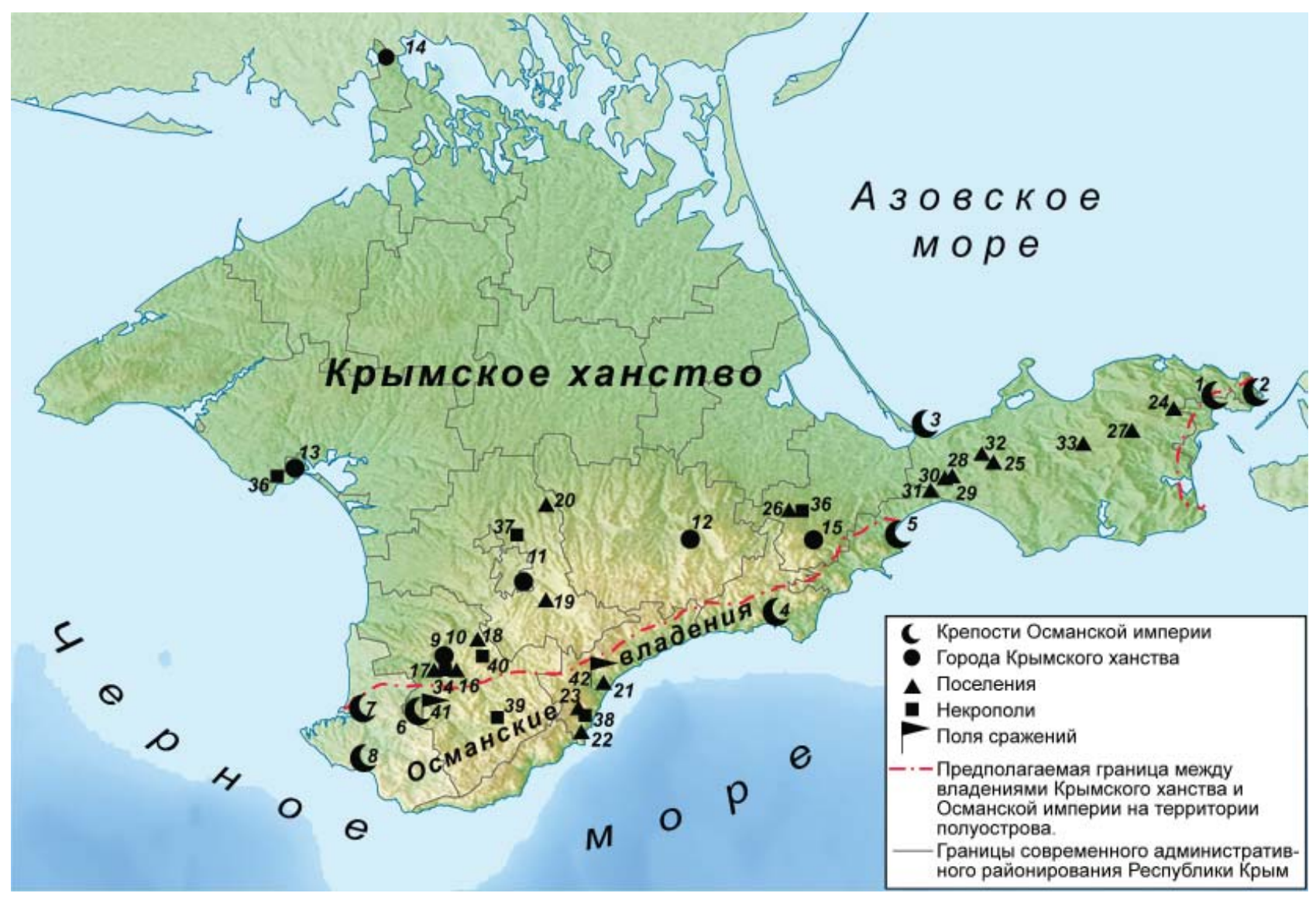

Рис. 2. Археологическая карта Крымского полуострова для периода 1475-1783 гг. с указанием наиболее важных памятников, затронутых раскопками последних десятилетий (составлена В.Е. Науменко и Э.И. Сейдалиевым):

Крепости Османской империи: 1 - Керчь; 2 - Ени-Кале; 3 - Арабат; 4 - Судак; 5 - Кефе; 6 - Мангуп;

7 - Инкерман; 8 - Балаклава. Города Крымского ханства: 9 - Бахчисарай; 10 - Чуфут-Кале; 11 - Ак-Мечеть;

12 - Карасубазар; 13 - Гезлев; 14 - Ор-Капу; 15 - Эски-Крым. Поселения: 16 - Салачик; 17 - Эски-Юрт;

18 - Сарымамбаш-Кермен; 19 - Эски-Сарай; 20 - Шейх-Кой; 21 - Алушта; 22 - Партенит; 23 - Биюк-Ламбат (Малый Маяк); 24 - Биели; 25 - Кегенез Восточное; 26 - Су-Баш; 27 - Кош-Кую; 28 - Батальное 1; 29 - Батальное Западное; 30 - Шибан I; 31 - Тюреке II; 32 - Королево 3; 33 - Фонтан 6. Некрополи: 34 - Салачик; 35 - Заозерное; 36 - Су-Баш; 37 - Живописное; 38 - Биюк-Ламбат (Малый Маяк); 39 - Богатырь; 40 - Прохладное. «Поля военных сражений»: 41 - Мангуп; 42 - Шумское сражение.

Fig. 2. Archaeological map of the Crimean peninsula for the period 1475-1783 indicating the most important monuments affected by the excavations of the last decades (composed by V.E. Naumenko and E.I. Seidaliev):

Fortresses of the Ottoman Empire: 1 - Kerch; 2 - Yeni-Kale; 3 - Arabat; 4 - Sudak; 5 - Kefe; 6 - Mangup; 7 - Inkerman; 8 - Balaklava. Cities of the Crimean Khanate: 9 - Bakhchisaray; 10 - Chufut-Kale; 11 - Ak-Mechet'; 12 - Karasubazar; 13 - Gezlev; 14 - Or-Kapu; 15 - Eski-Crym. Settlements: 16 - Salachik; 17 - Eski-Yurt; 18 - SarymambashKermen; 19 - Eski-Saray; 20 - Sheikh-Coy; 21 - Alushta; 22 - Partenit; 23 - Biyuk-Lambat (Malyi Mayak); 24 - Bieli;

25 - Kegenez Vostochnoye; 26 - Su-Bash; 27 - Kosh-Kuyu; 28 - Batal'noye 1; 29 - Batal'noye Zapadnoye;

30 - Shiban I; 31 - Tyreke II; 32 - Korolevo 3; 33 - Fontan 6.Necropolis: 34 - Salachik; 35 - Zaozernoye; 36 - Su-Bash; 37 - Zhivopisnoye; 38 - Biyuk-Lambat (Malyi Mayak); 39 - Bogatyr'; 40 - Prokhladnoye.

"Battlefields": 41 - Mangup; 42 - Shum battle. 


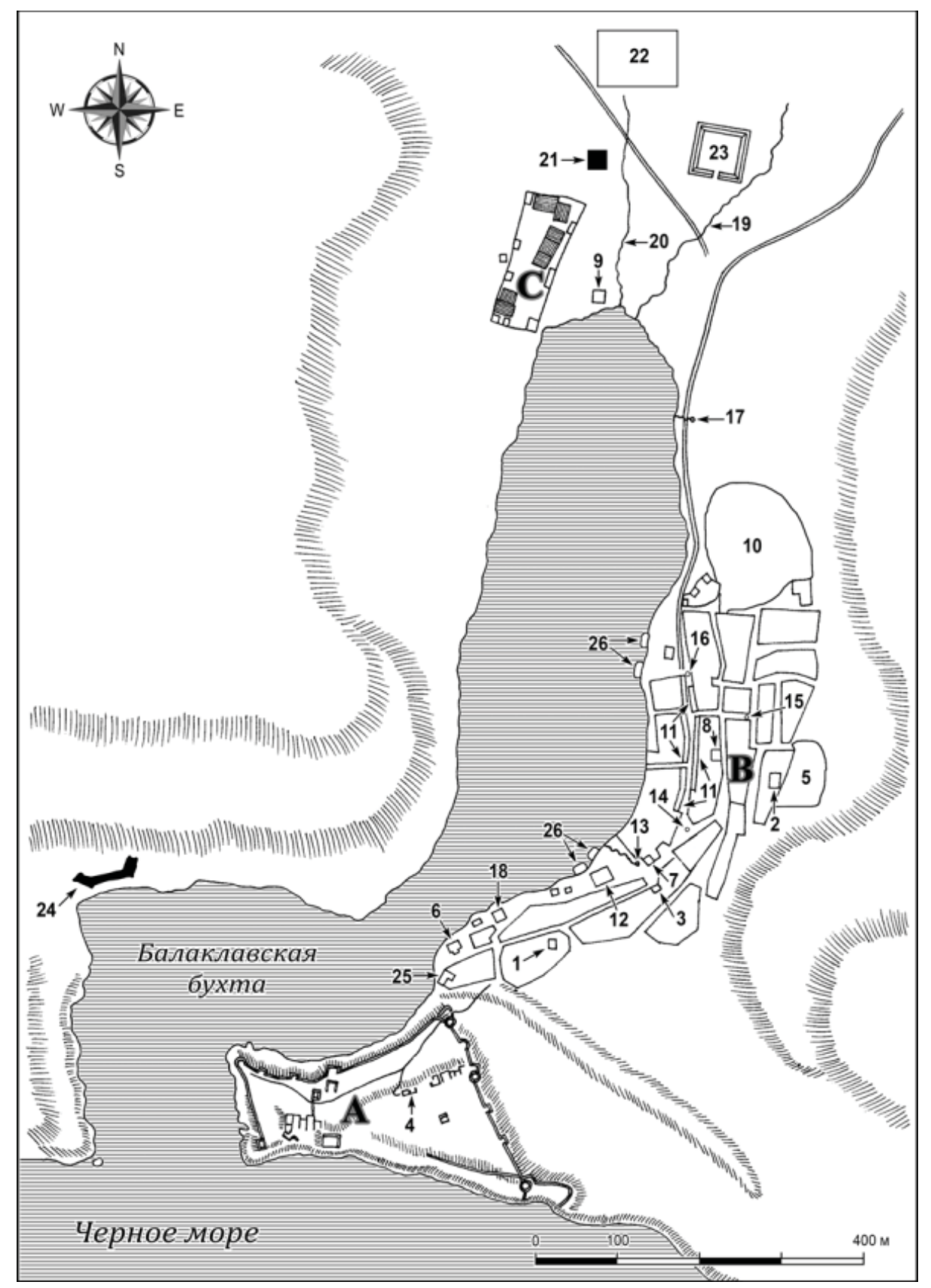

Рис. 3. Реконструкция генерального плана города Балаклава для второй половины XVIII в.: A - руинированные остатки генуэзской крепости Чембало, которая на протяжении XVI-XVII вв. использовалась османским гарнизоном; В — город Балаклава; С - северное предместье; 1 - 3 - греческие церкви; 4 - армянская церковь; 5 - греческое кладбище; 6-8 - городские мечети; 9 - мечеть в северном предместье; 10 - турецкое кладбище; 11 - рыночная площадь, лавки, кофейни и торговые места; 12 — караван-сарай; 13-17 - фонтаны; 18 - карантинный дом; 19-20 - ручьи у северного предместья; 21 - черепичный завод в северном предместье; 22 - виноградники у северного предместья; 23 - редут, построенный российскими войсками в 1771 г;; 24 - батарея, построенная российскими войсками в 1771 г; 25 - баня; 26 - деревянные пристани (по: Бочаров, 2019, с. 324, рис. 3).

Fig. 3. Reconstruction of general plan of the city of Balaklava for the second half of the XVIII century: A - the ruined remains of the Genoese fortress Cembalo, which during the XVI-XVII centuries was used by the Ottoman garrison; B - the city Balaklava; C - the northern suburb; 1-3 - Greek Churches; 4 - Armenian Church; 5 - the Greek cemetery; 6-8 - city mosques; 9 - a mosque in a northern suburb; 10 - the Turkish cemetery; 11 - market square, shops, cafes, and shopping places; 12 - caravanserais; 13-17 - fountains; 18 - quarantine building; 19-20 - streams in the northern suburbs; 21 - a tile factory in the northern suburb; 22 - vineyards near the northern suburb; 23 - a redoubt built

by Russian troops in 1771; 24 - a battery built by Russian troops in 1771; 25 - a bathhouse; 26 - wooden piers (according to: Bocharov, 2019, p. 324, fig. 3). 


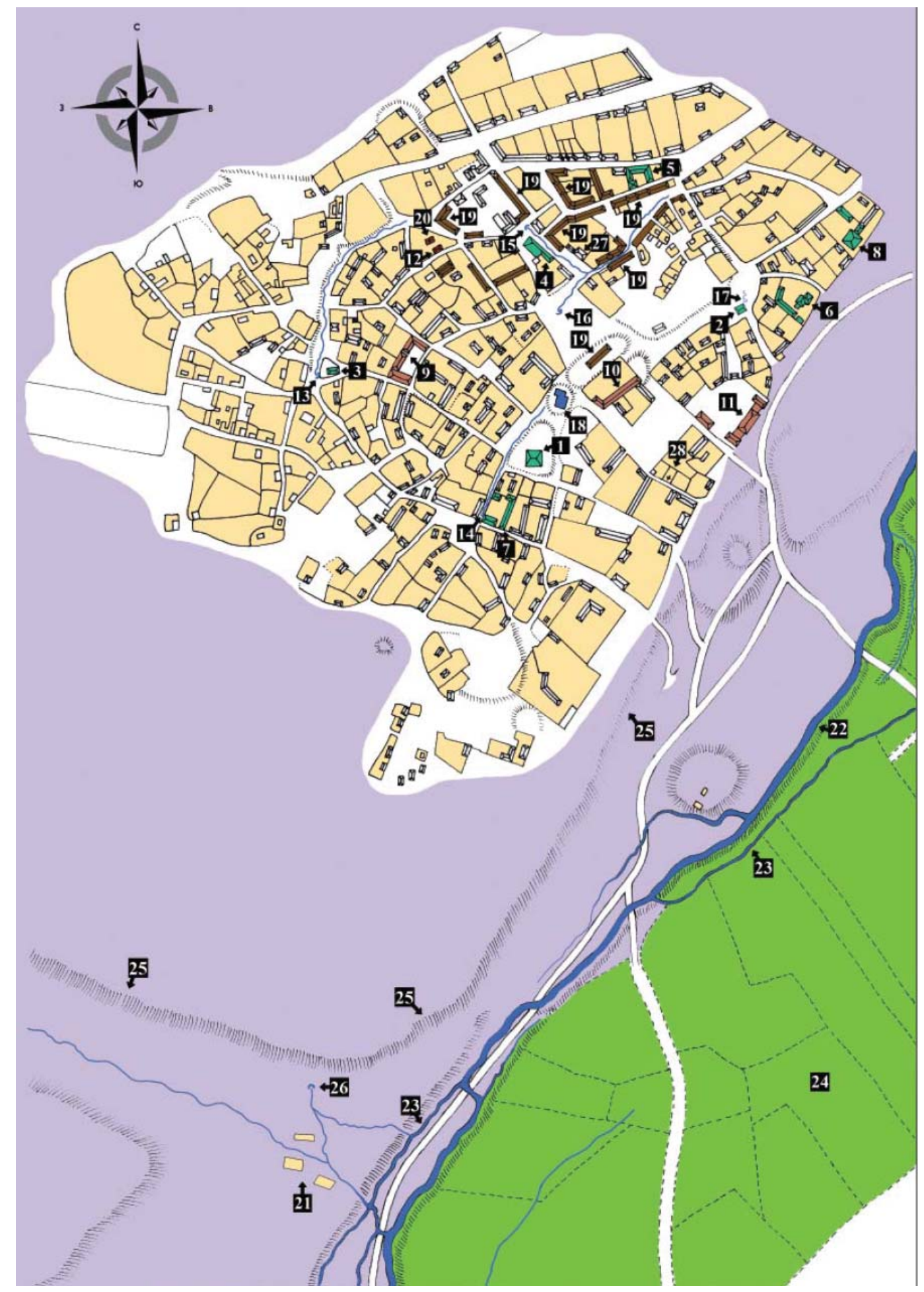

Рис. 4. Город Ак-Мечеть. Реконструкция генерального плана: 1 - Кебир Джами (Ак-Мечеть); 2-3 - мечети; 4-6 - теккие; 7-8 - медресе; 9-11 - караван-сараи; 12 - Гостевой дом иностранных купцов; 13-17 - фонтаны; 18 - баня; 19 - лавки, торговые места; 20 - храм в гостевом доме иностранных купцов; 21 - местонахождение пригорода, где располагался дворец калги-султана; 22 - река Салгир; 23 - каналы на реке Салгир; 24 - сады и огороды; 25 - скальные обрывы; 26 - фонтан в пригороде; 27 - Русская церковь конца XVIII в.; 28 - Греческая церковь (по: Бочаров, 2015, с. 6, рис. 1).

Fig. 4. The city of Ak-Mechet'. Reconstruction of the general plan: 1 - Kebir Jami (Ak-Mosque); 2-3 - mosques; 4-6 tekke; 7-8 - madrasahs; 9-11 - caravanserais; 12 - Guest House of foreign merchants; 13-17 - fountains; 18 - bath; 19 - shops, shopping places; 20 - churche in the Guest House of foreign merchants; 21 - location of the suburb where the palace of Kalgi Sultan was located; 22 - Salgir river; 23 - chanals on the Salgir river; 24 - gardens and vegetable gardens; 25 - rock cliffs; 26 - fountain in the suburbs; 27 - Russian church of the late XVIII century; 28 - Greek church (according to: Bocharov, 2015, p. 6, fig.1). 


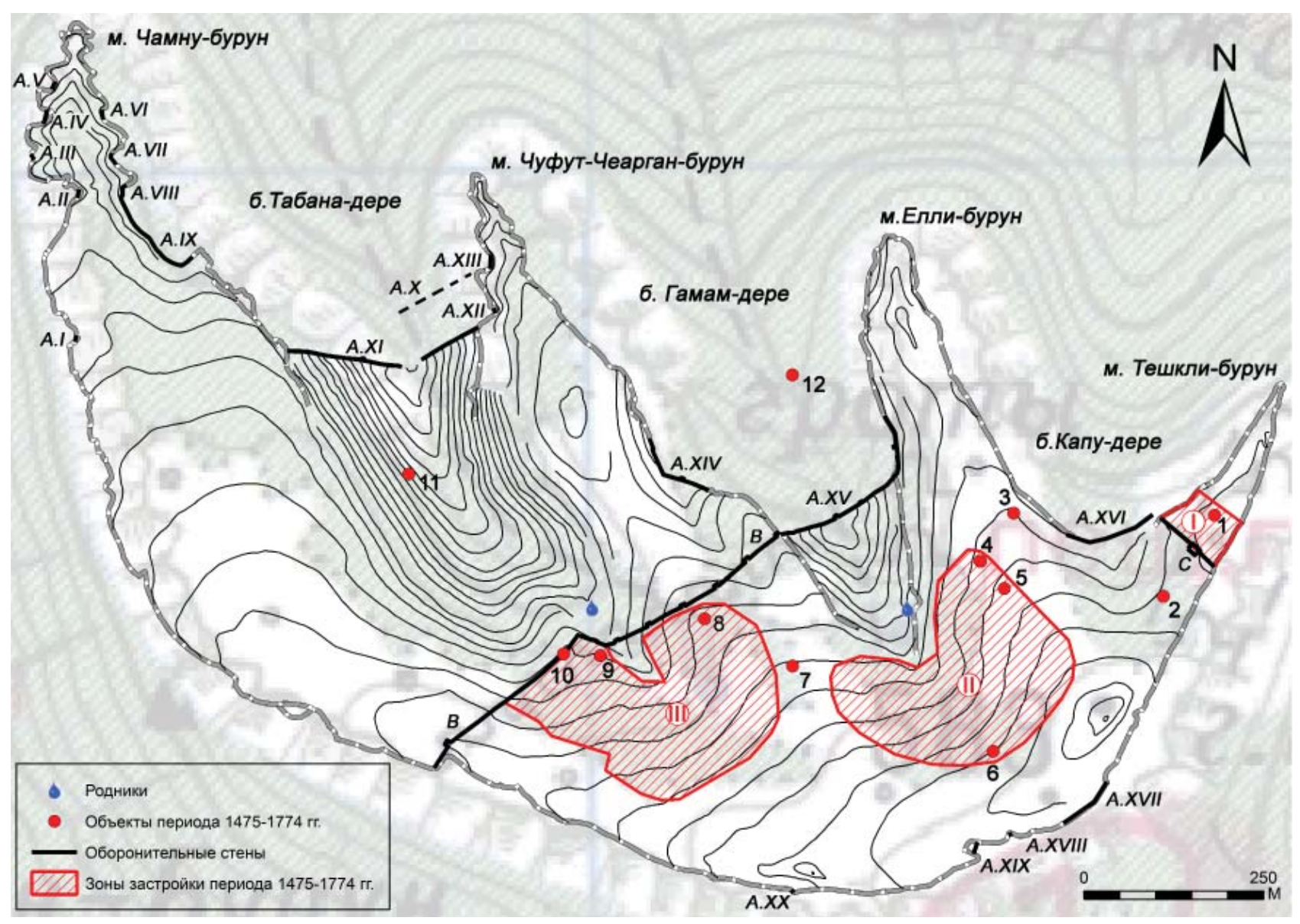

Рис. 5. Археологическая карта Мангупского городища периода 1475-1774 гг.: А.I-XX - укрепления Главной (Внешней) линии обороны крепости; В - Вторая (Внутренняя) линия обороны; C - цитадель; I - мусульманский квартал XVI-XVII вв. у тыльной стороны цитадели; II - мусульманский квартал XVII-XVIII вв. в верховьях балки Гамам-дере; III - иудейский квартал XVI-XVIII вв. в верховьях балки Табана-дере; 1 - мечеть на месте октагонального христианского храма XV в.; 2 - Главная (Джами) мечеть крепости; 3 - церковь св. Георгия;

4 - мусульманский некрополь XVII-XVIII вв.; 5 - мечеть (?) на месте «церкви 1969 г.»; 6 - церковь св.

Константина; 7 - дворец 1425-1475 гг.; 8 - Большая трехнефная базилика; 9 - синагога-кенасса; 10 - «городская свалка» второй половины XVII - начала XVIII вв.; 11 - караимский некрополь; 12 - артиллерийская позиция османской армии времени осады 1475 г. (составлена В.Е. Науменко и А.А. Душенко).

Fig. 5. Archaeological map of the Mangup fortress of the period 1475-1774: A.I-XX - fortifications of the Main (External) line of defense of the fortress; B - the Second (Internal) line of defense; C - the Citadel; I - the Muslim quarter of the XVI-XVII centuries at the back of the citadel; II - Muslim quarter of the XVII-XVIII centuries in the upper reaches of the Gamam-dere gully; III - Jewish quarter of the XVI-XVIII centuries. in the upper reaches of the Tabana-dere gully; 1 - Mosque on the site of the octagonal christian church of the XV century; 2 - the Main (Jami) Mosque of the fortress; 3 - St. George's church; 4 - Muslim necropolis of the XVII-XVIII centuries; 5 - Mosque (?) on the site of the «church of 1969»; 6 - St. Constantine's church; 7 - the Palace of 1425-1475; 8 - The Large three-nave Basilica; 9 - Synagogue-Kenassa; 10 - «city dump» of the second half of the XVII - early XVIII centuries; 11 - Karaite necropolis; 12 - Artillery Position of the Ottoman army during the siege of 1475 (composed by V. E. Naumenko and A. A. Dushenko). 


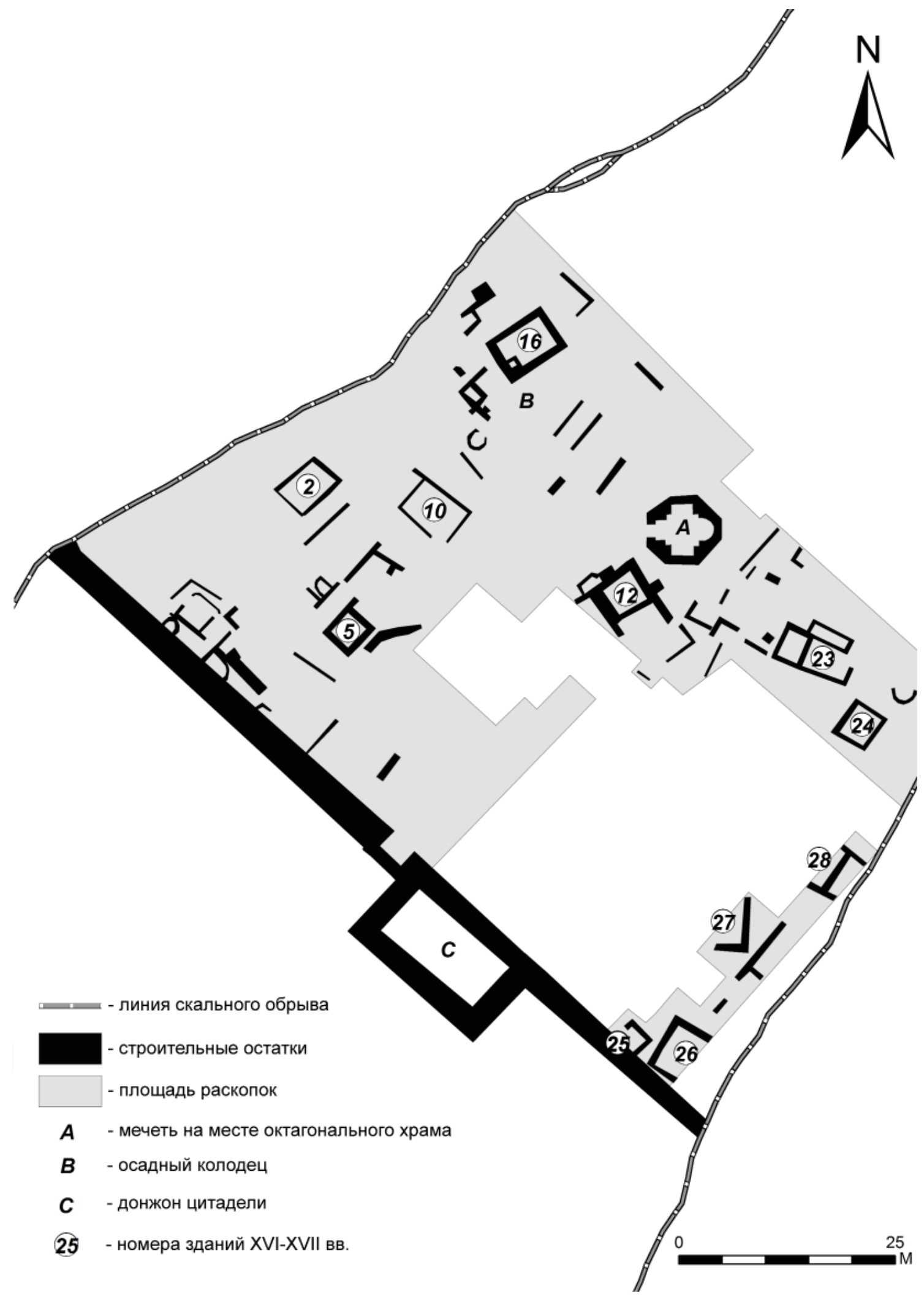

Рис. 6. Мангупское городище. Цитадель на мысе Тешкли-бурун. Строительный ярус XVI-XVII вв. Общий план по материалам раскопок 1970-1971, 1990-2005 гг. (составлен В.Е. Науменко и А.Г. Герценым).

Fig. 6. Mangup fortress. Citadel on cape Teshkli-burun. Building tier XVI-XVII centuries. General plan based on the materials of the excavations 1970-1971, 1990-2005 (composed by V.E. Naumenko and A.G. Gertsen). 


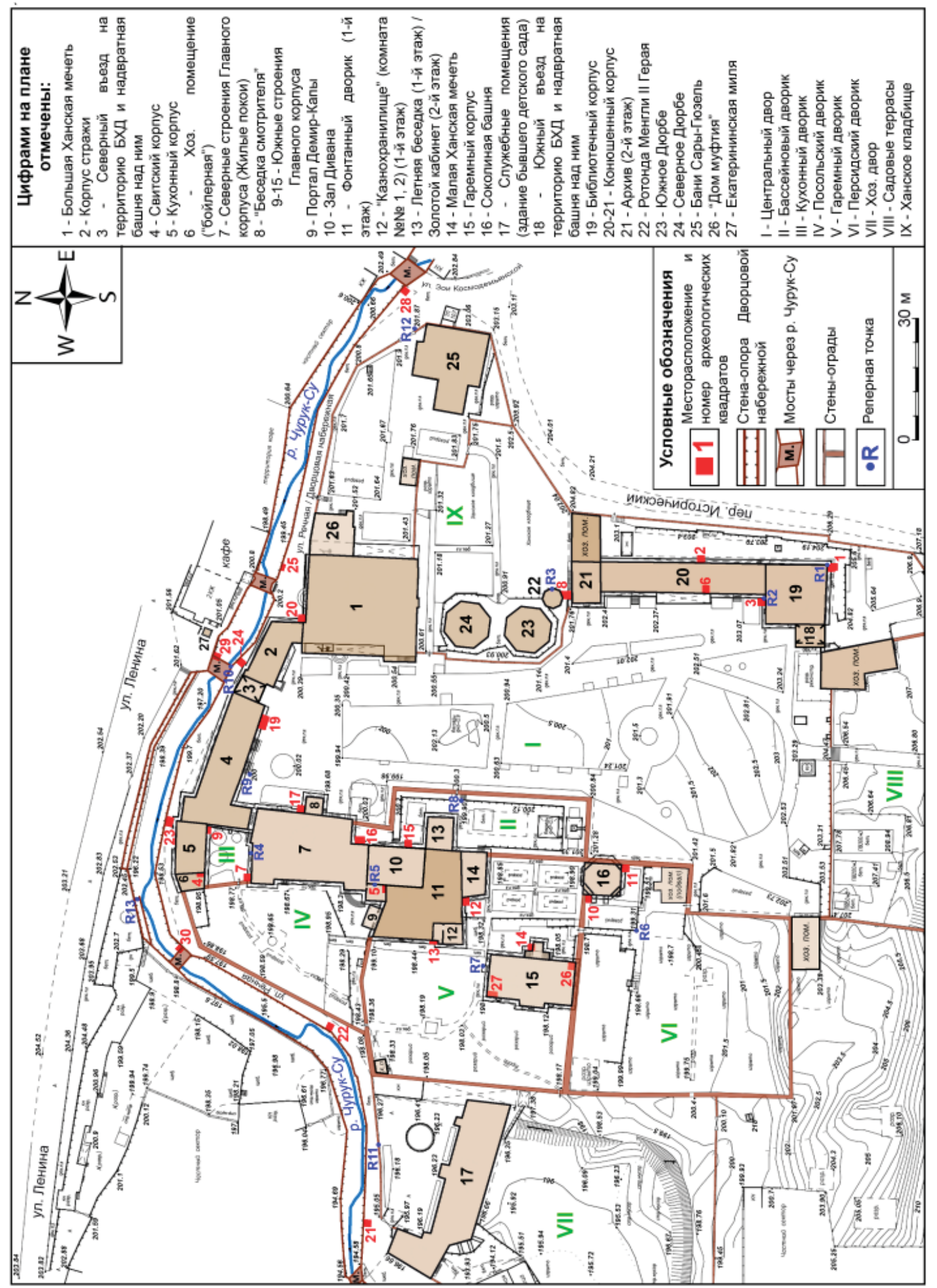



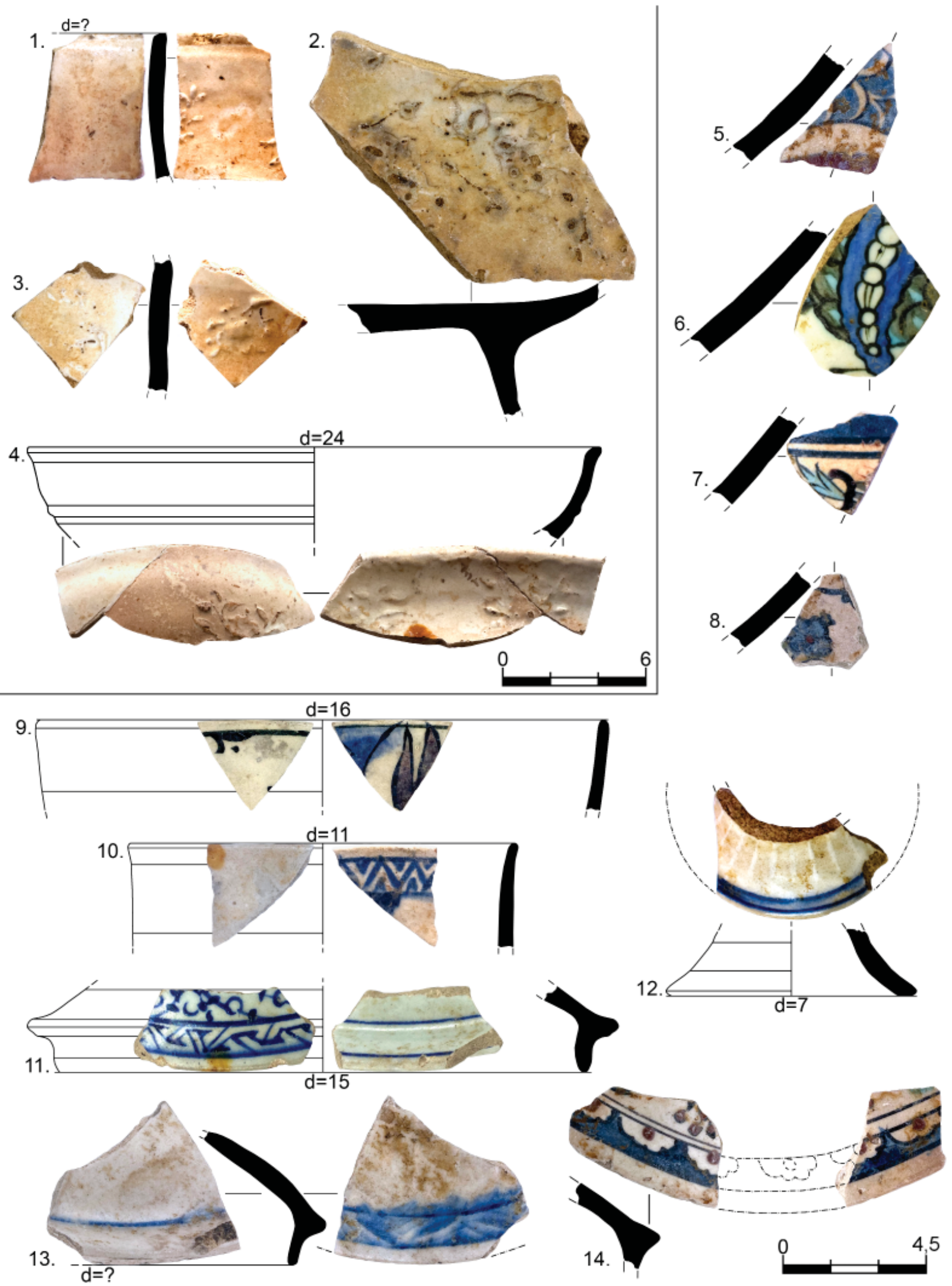

Рис. 8. Бахчисарайский Ханский дворец. Раскопки 2018-2019 гг. Османский фаянс группы «Iznik Ware» из археологического комплекса второй половины XVI - первой половины XVII вв. на месте современного Гаремного корпуса.

Fig. 8. Bakhchisaray Khan's Palace. Excavations 2018-2019. Ottoman faience of the «Iznik Ware» group from the archaeological complex of the second half of the XVI - first half of the XVII centuries on the site of the modern Harem building. 


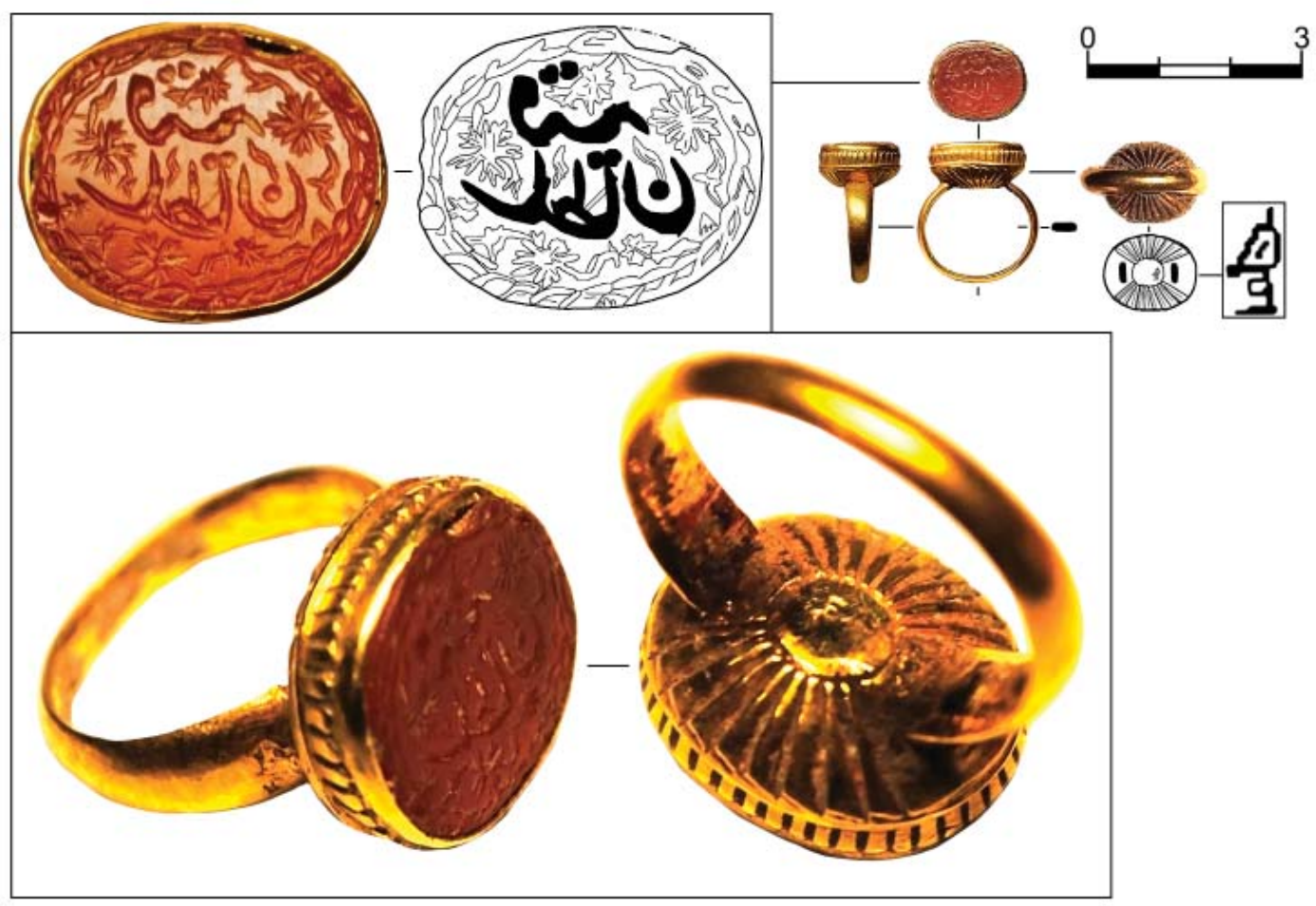

Рис. 9. Бахчисарайский Ханский дворец. Раскопки 2018-2019 гг. Золотой перстень с именем «Кая (или Кыйа)султан», дочери хана Селим-Гирея II (1743-1748), из слоя разрушения постройки конца XVII - начала XVIII вв. на месте Соколиной башни (чтение надписи И.В. Зайцева).

Fig. 9. Bakhchisaray Khan's Palace. Excavations 2018-2019. A gold ring with the name "Kaya (or Kyia)-Sultan", the daughter of Khan Selim Giray II (1743-1748), from the layer of destruction of building of the late XVII - early XVIII centuries on the place of Sokolinaya tower (reading of inscription by I. V. Zaitsev). 

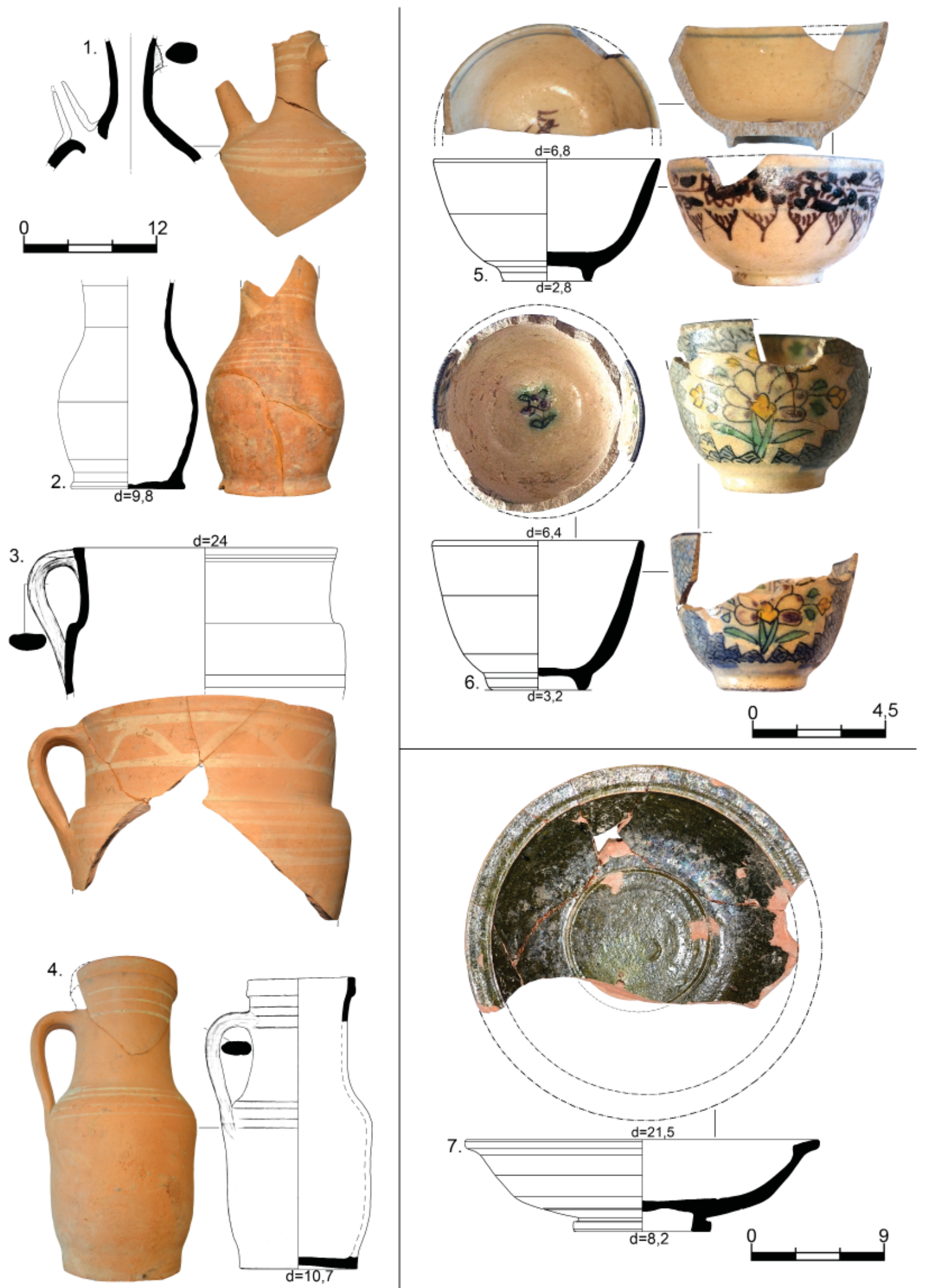

Рис. 10. Бахчисарайский Ханский дворец. Раскопки 2018-2019 гг. Свитский корпус. Хозяйственная яма №5 (около 1750-1775 гг.). Заполнение. Образцы бытовой керамики с росписью линиями светлого ангоба (1-4), османского фаянса группы «Kütahya Ware» (5-6), глазурованной посуды группы «Monochrome (Green) Glazed Ware» (группа «Крым») (7).

Fig. 10. Bakhchisaray Khan's Palace. Excavations 2018-2019. Svitskiy building. Grain pit No. 5 (about 1750-1775). Filling. Samples of household ceramics with painted lines of light angobe (1-4), Ottoman faience of the group "Kütahya Ware" (5-6), glazed dishes of the group "Monochrome (Green) Glazed Ware" (group "Crimea") (7). 

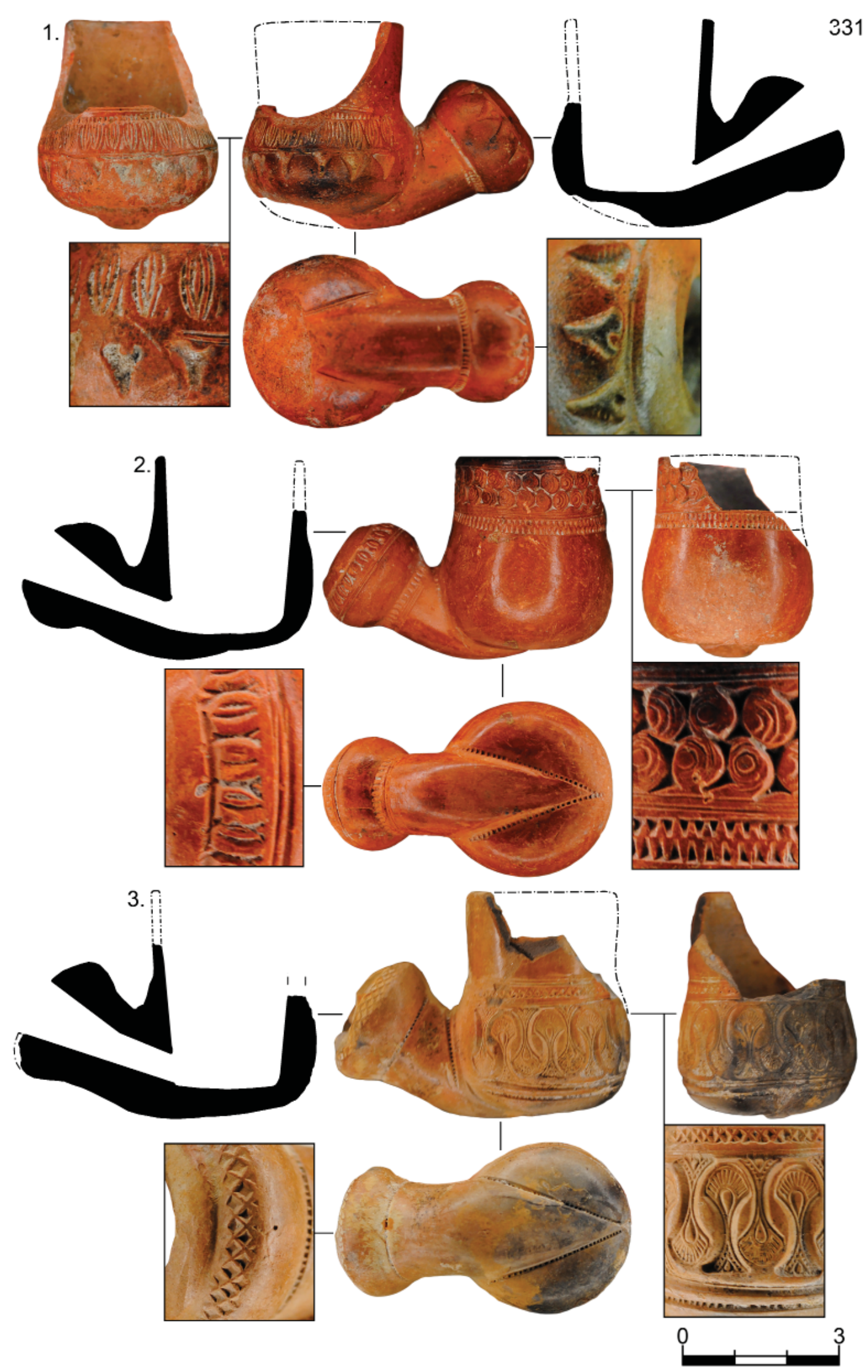

Рис. 11. Бахчисарайский Ханский дворец. Раскопки 2018-2019 гг. Свитский корпус. Хозяйственная яма №5 (около 1750-1775 гг.). Заполнение. Образцы османских курительных трубок.

Fig. 11. Bakhchisaray Khan's Palace. Excavations 2018-2019. Svitskiy building. Grain pit No. 5 (about 1750-1775). Filling. Samples of Ottoman tobacco pipes. 


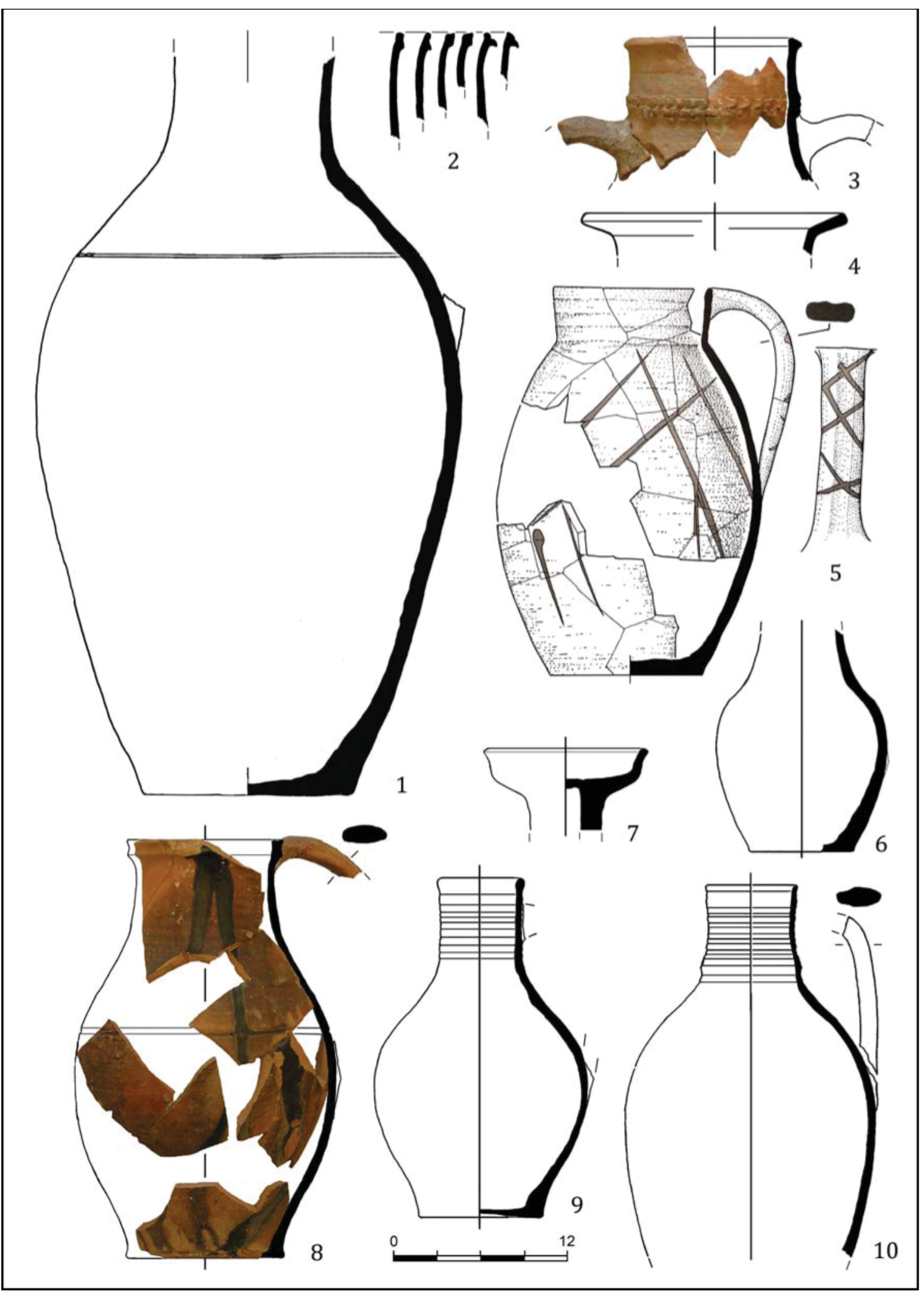

Рис. 12. Неглазурованная керамика Крыма конца XV - начала XVII вв. из раскопок Судака (1-4, 6-10) и Алушты (5): 1-7 - группа «Юго-Восточный Крым»; 8-10 - «подражания группы «горшков с рельсовидным венчиком» (по: Тесленко, Алядинова, 2019, с. 304, рис. 5).

Fig. 12. Unglazed pottery of the Crimea of the late XV - early XVII centuries from the excavations of Sudak (1-4, 6-10) and Alushta (5): 1-7 - group "South-Eastern Crimea"; 8-10 - "imitations of the "Pots with rails-shape rims" group" (according to: Teslenko, Aladinova, 2019, p. 304, fig.5). 


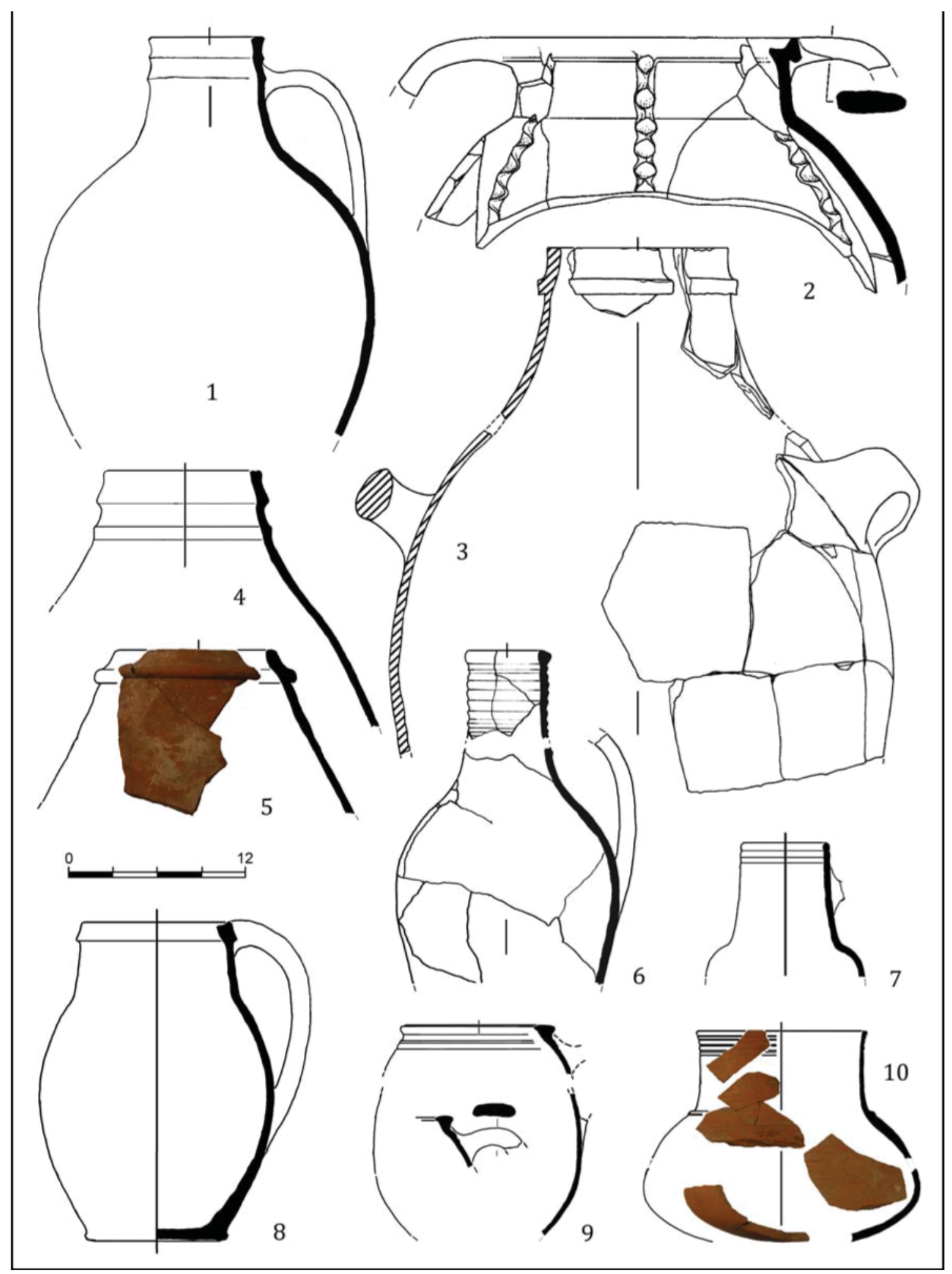

Рис. 13. Неглазурованная керамика Крыма конца XV - начала XVII вв. Группа «горшков с рельсовидным венчиком» из раскопок Судака (1, 4-10), Алушты (2) и Партенита (3) (по: Тесленко, Алядинова, 2019, с. 302, рис. 4).

Fig. 13. Unglazed pottery of the Crimea of the late XV - early XVII centuries. The "Pots with rails-shape rims" group from the excavations of Sudak (1, 4-10), Alushta (2) and Partenit (3) (according to: Teslenko, Aladinova, 2019, p. 302, fig.4). 

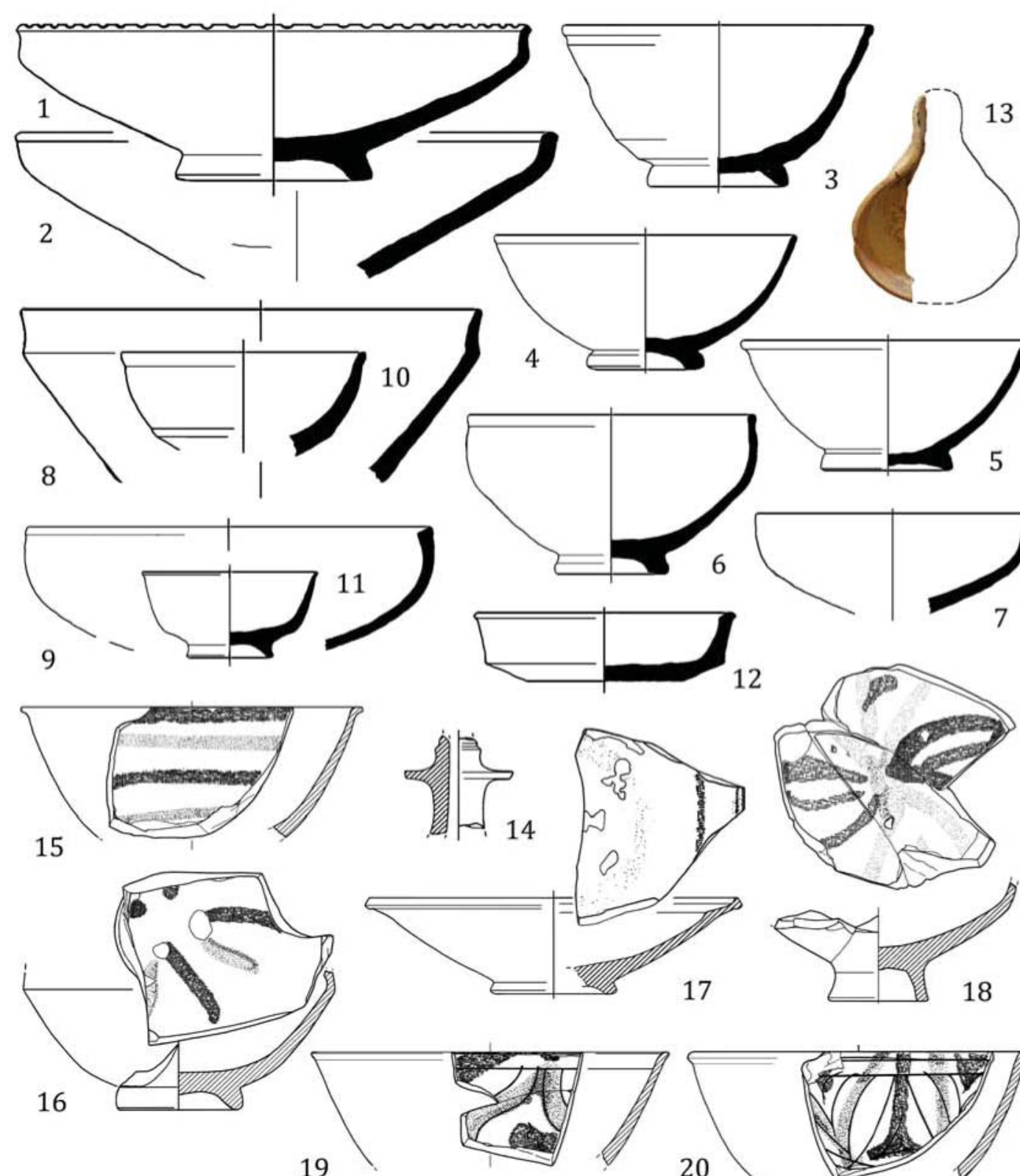

19
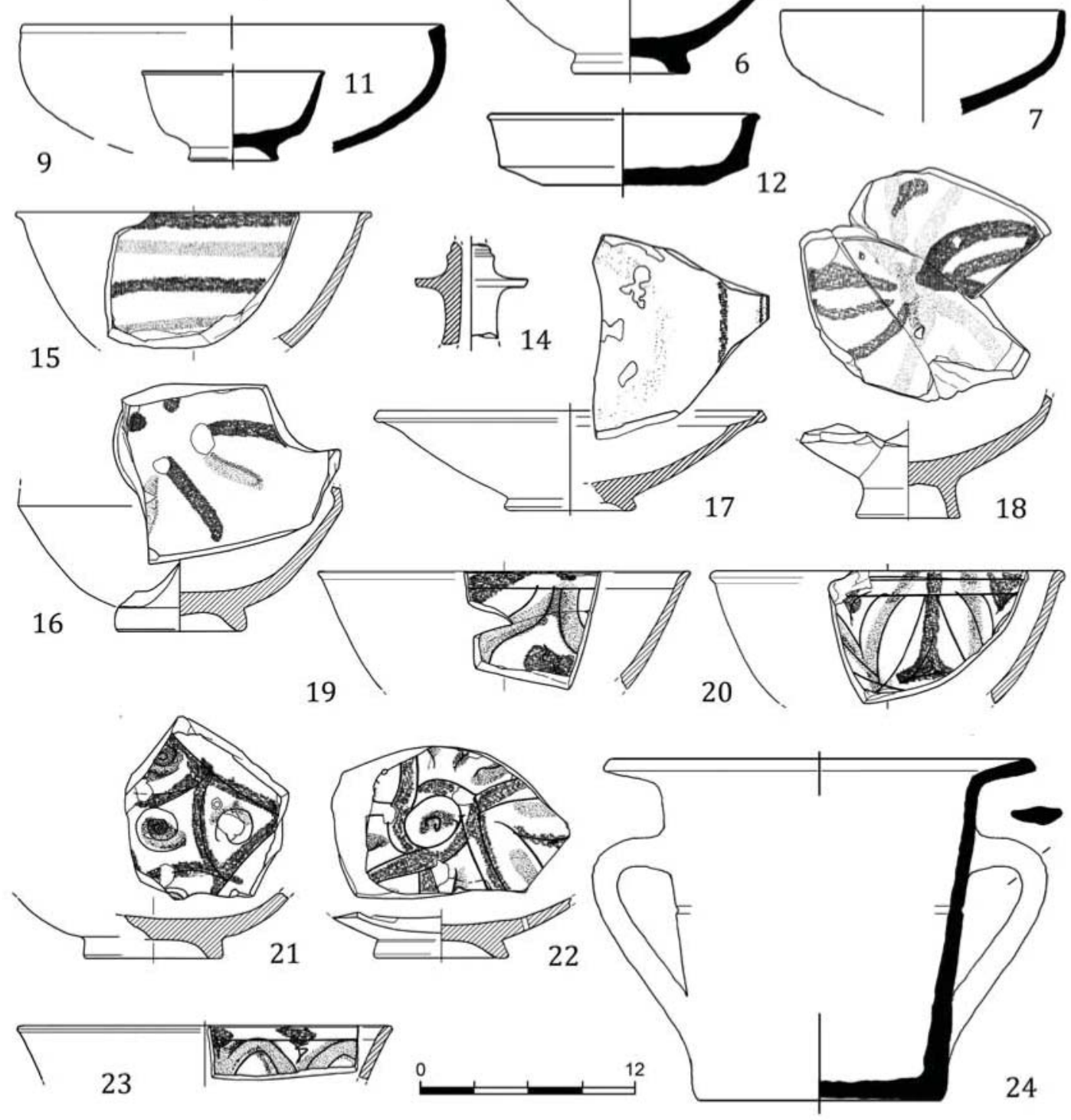

Рис. 14. Поливная керамика Крыма конца XV - начала XVII вв. Группа «Юго-Восточный Крым» из раскопок Судака $(1-13,24)$ и Алушты (14-23) (по: Тесленко, Алядинова, 2019, с. 307, рис. 6).

Fig. 14. Glazed Pottery of the Crimea of the late XV - early XVII centuries. A Group of "South-Eastern Crimea" from the excavations of Sudak (1-13, 24) and Alushta (14-23) (according to: Teslenko, Aladinova, 2019, p. 307, fig. 6). 


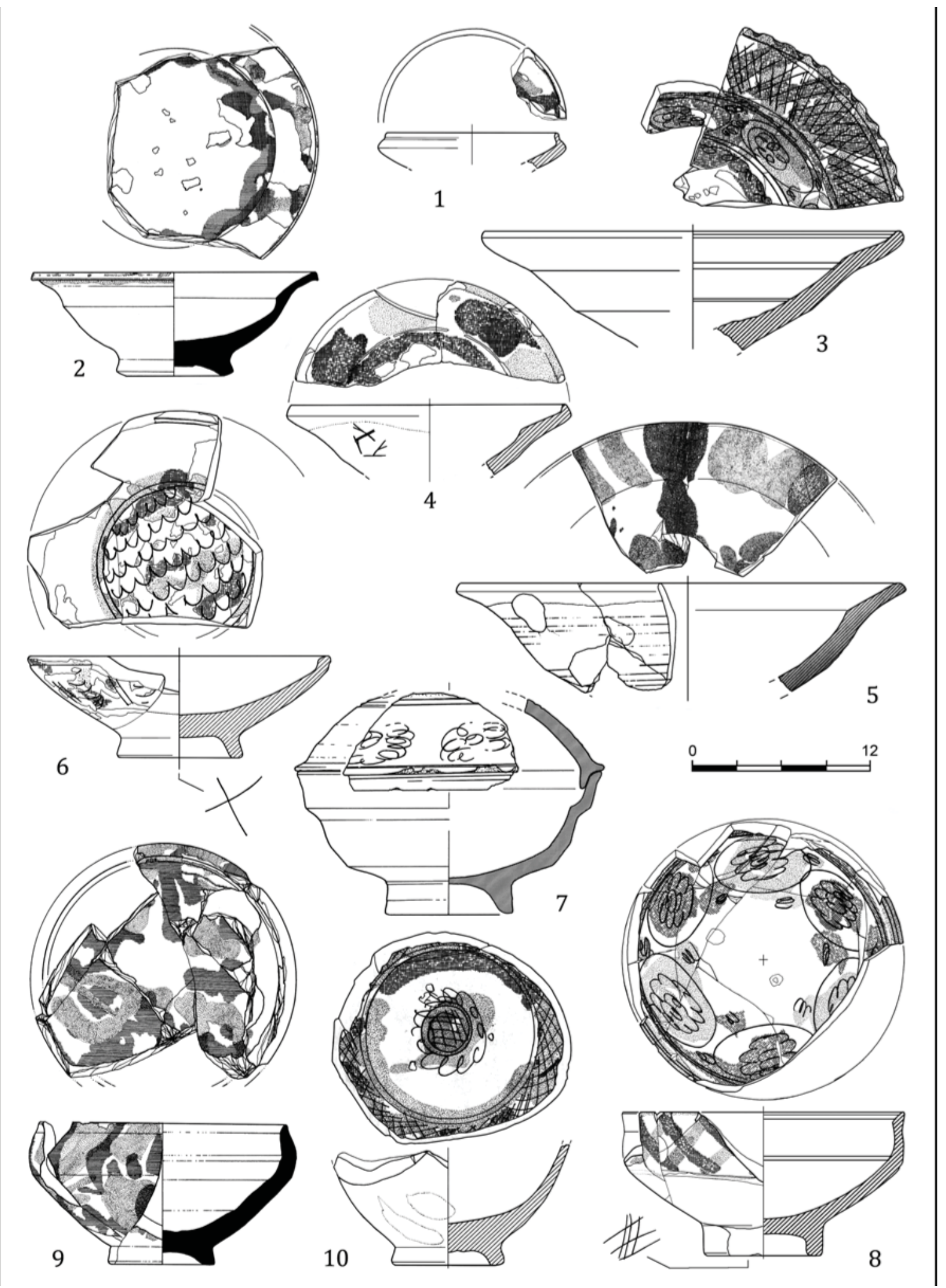

Рис. 15. Поливная керамика Крыма конца XV - начала XVII вв. периода. Группа «толстостенных чаш с бихромной расцветкой» из раскопок Алушты $(2,4-6,9-10)$, Партенита $(1,3,8)$ и Балаклавы (7) (по: Тесленко, Алядинова, 2019, с. 310, рис. 7).

Fig. 15. Glazed Pottery of the Crimea of the late XV - early XVII centuries. A group of "thick-walled bowls with bichromic painting" from the excavations of Alushta (2, 4-6, 9-10), Partenite $(1,3,8)$ and Balaklava (7) (according to: Teslenko, Aladinova, 2019, p. 310, fig. 7). 


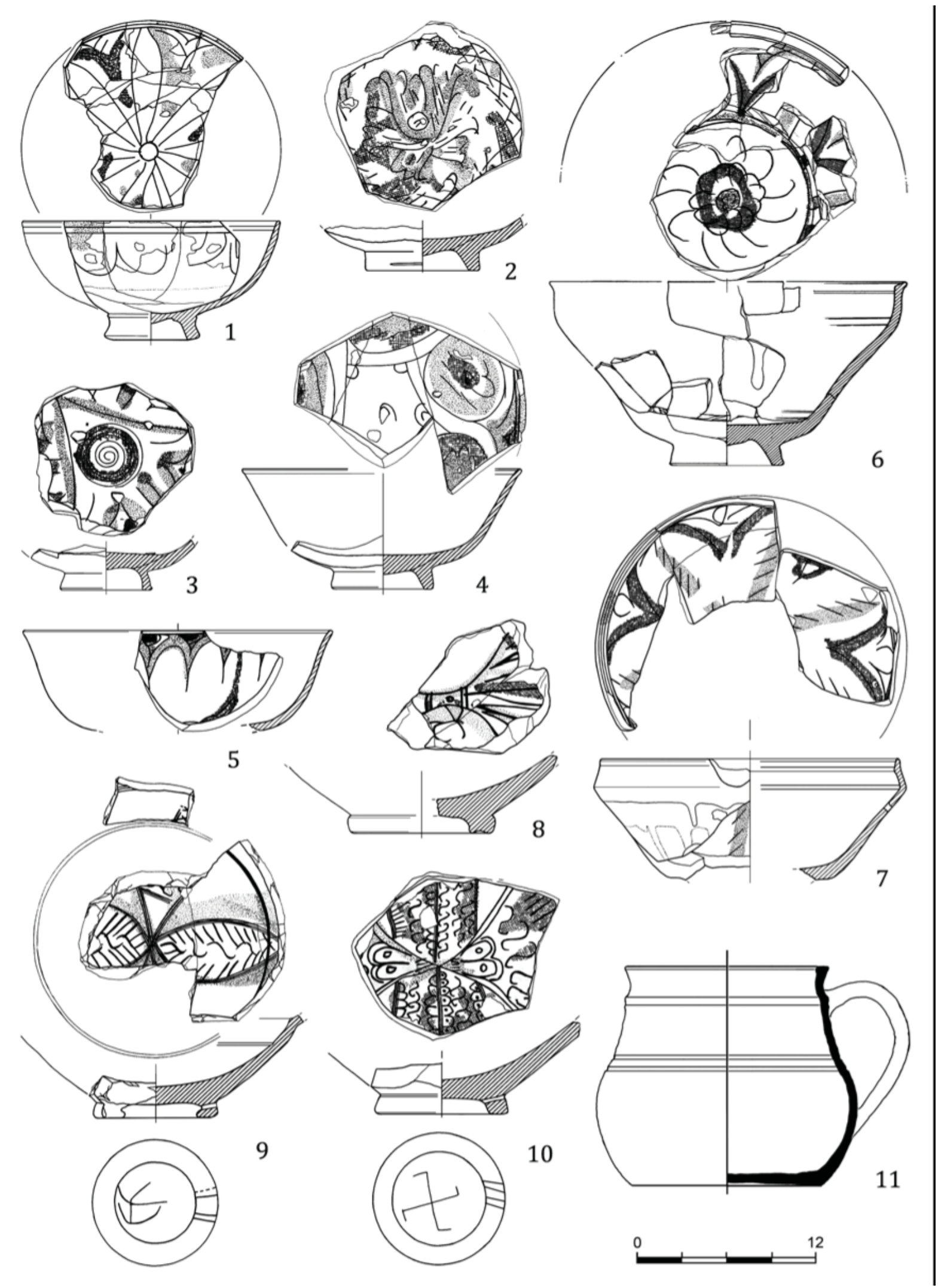

Рис. 16. Поливная керамика Крыма конца XV - начала XVII вв. периода из раскопок Алушты (1-5, 7-10), Малого Маяка (6) и Судака (11): 1-7 - группа «Мангуп»; 8-11 - османская поливная керамика (по: Тесленко, Алядинова, 2019, с. 311, рис. 8).

Fig. 16. Glazed Pottery of the Crimea of the late XV - early XVII centuries from the excavations of Alushta (1-5, 7-10), Maly Mayak (6) and Sudak (11): 1-7 - group "Mangup"; 8-11 - Ottoman glazed pottery (according to: Teslenko, Aladinova, 2019, p. 311, fig.8). 


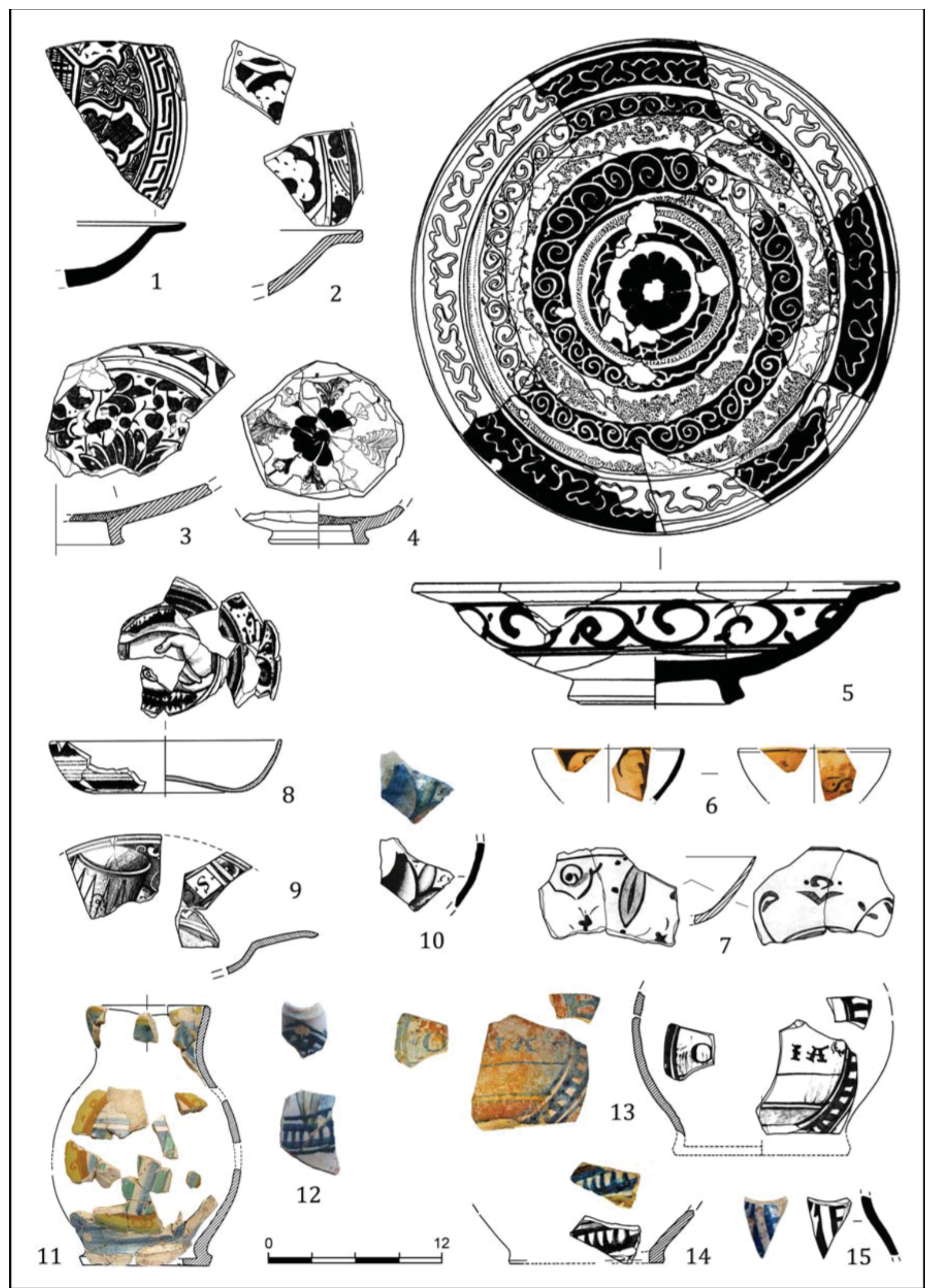

Рис. 17. Поливная керамика Крыма конца XV - начала XVII вв. периода из раскопок Алушты (1-5, 7, 10, 13-15), Балаклавы (8-9, 12) и Малого Маяка (11): 1-5 - группа «Miletus Ware»; 6-7 - фаянс группы «Iznik Ware»; 8-15 группа «Maiolica Rinascimentali» (по: Тесленко, Алядинова, 2019, с. 312, рис. 9).

Fig. 17. Glazed Pottery of the Crimea of the late XV - early XVII centuries from the excavations of Alushta (1-5, 7, 10, 13-15), Balaklava (8-9, 12) and Maly Mayak (11): 1-5 - group "Miletus Ware"; 6-7 - faience group "Iznik Ware"; 8-15 - group "Maiolica Rinascimentali" (according to: Teslenko, Aladinova, 2019, p. 312, fig.9). 